Volume 9

Issue 1 The Edge of the Known is Infinite:

Original Contributions in Undergraduate

Article 10

Research

2015

The Edge of the Known is Infinite: Original

Contributions in Undergraduate Research (Full Issue)

Follow this and additional works at: https://pdxscholar.library.pdx.edu/mcnair

Let us know how access to this document benefits you.

Recommended Citation

(2015) "The Edge of the Known is Infinite: Original Contributions in Undergraduate Research (Full Issue)," PSU McNair Scholars Online Journal: Vol. 9: Iss. 1, Article 10.

https://doi.org/10.15760/mcnair.2015.01

This open access Full Issue is distributed under the terms of the Creative Commons Attribution-NonCommercialShareAlike 4.0 International License (CC BY-NC-SA 4.0). All documents in PDXScholar should meet accessibility standards. If we can make this document more accessible to you, contact our team. 


\section{PSU McNair Scholars Online Journal}

$\begin{array}{ll}\text { Volume } 9 & \text { Article } 1 \\ \text { Issue } 1 \text { The Edge of the Known is Infinite: Original } & \\ \text { Contributions in Undergraduate Research } & \end{array}$

2015

\section{Front Matter Volume 9, 2015}

\section{McNair Scholars Program}

Portland State University

\section{Let us know how access to this document benefits you.}

Follow this and additional works at: http://pdxscholar.library.pdx.edu/mcnair

\section{Recommended Citation}

Program, McNair Scholars (2015) "Front Matter Volume 9, 2015," PSU McNair Scholars Online Journal: Vol. 9: Iss. 1, Article 1.

This Front Matter is brought to you for free and open access. It has been accepted for inclusion in PSU McNair Scholars Online Journal by an authorized administrator of PDXScholar. For more information, please contact pdxscholar@pdx.edu. 


\section{The Edge of the Known is Infinite:}

\section{Original Contributions in Undergraduate Research}

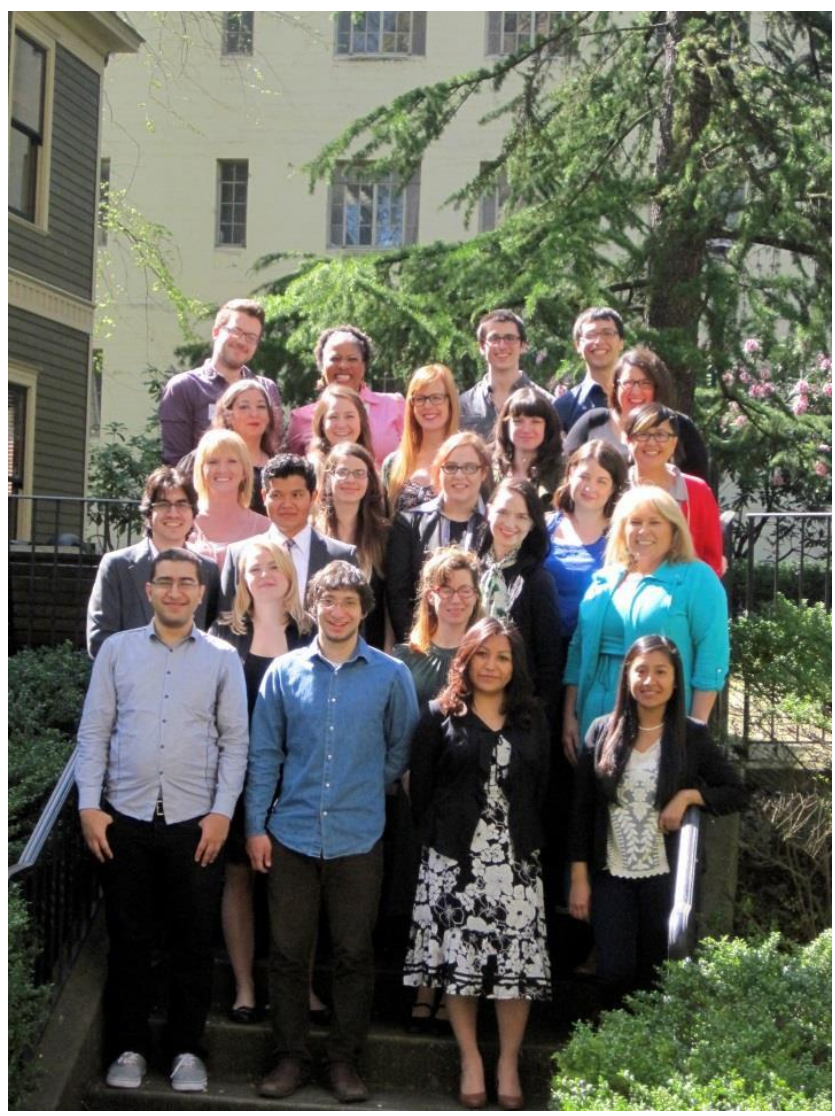

2015

Ronald E. McNair Scholars Journal

Portland State University 


\section{About the Program}

The Portland State University (PSU) Ronald E. McNair Scholars Program at Portland State University works with motivated and talented undergraduates who want to pursue PhDs. It introduces juniors and seniors who are first-generation and lowincome, and/or members of under-represented groups to academic research and to effective strategies for getting into and graduating from PhD programs.

The McNair Scholars Program has academic-year activities and a full-time summer research internship. Scholars take academic and skills-building seminars and workshops during the year, and each scholar works closely with a faculty mentor on original research in the summer. Scholars present their research findings at the McNair Summer Symposium and at other conferences, and are encouraged to publish their papers in the McNair Journal and other scholarly publications.

The Ronald E. McNair Post-baccalaureate Achievement Program was established in 1986 by the U.S. Department of Education and named in honor of Challenger Space Shuttle astronaut Dr. Ronald E. McNair. The program, whichhas been on campus since 2003 , is funded by a $\$ 1,155,000$ grant from the U.S. Department of Education and institutional cost-share funds.

The McNair Scholars Program's student-centered approach relies heavily on faculty and university commitment. Activities and opportunities provided by the program focus on building a positive academic community for the scholars while they are undergraduates at PSU. 


\section{About Ronald E. McNair}

Ronald Erwin McNair was born October 21, 1950 in Lake City, South Carolina. While in junior high school, Dr. McNair was inspired to work hard and persevere in his studies by his family and by a teacher who recognized his scientific potential and believed in him. Dr. McNair graduated as valedictorian from Carver High School in 1967. In 1971, he graduated magna cum laude and received a Bachelor of Science degree in Physics from North Carolina A\&T State University (Greensboro). Dr. McNair then enrolled in the prestigious Massachusetts Institute of Technology. In 1976, at the age of 26, he earned his Ph.D. in laser physics. His dissertation was titled, "Energy Absorption and Vibrational Heating in Molecules Following Intense Laser Excitation." Dr. McNair was presented an honorary doctorate of Laws from North Carolina A\&T State University in 1978, an honorary doctorate of Science from Morris College in 1980, and an honorary doctorate of science from the University of South Carolina in 1984.

While working as a staff physicist with Hughes Research Laboratory, Dr. McNair soon became a recognized expert in laser physics. His many distinctions include being a Presidential Scholar (1971-74), a Ford Foundation Fellow (1971-74), a National Fellowship Fund Fellow (1974-75), and a NATO Fellow (1975). He was also a sixth degree black belt in karate and an accomplished saxophonist. Because of his many accomplishments, he was selected by NASA for the space shuttle program in 1978.

His first space shuttle mission launched successfully from Kennedy Space Center on February 3, 1984. Dr. Ronald E. McNair was the second African American to fly in space. Two years later he was selected to serve as mission specialist aboard the illfated U.S. Challenger space shuttle. He was killed instantly when the Challenger exploded one minute, thirteen seconds after it was launched. Dr. McNair was posthumously awarded the Congressional Space Medal of Honor. After his death in the Challenger Space Shuttle accident on January 28, 1986, members of Congress provided funding for the Ronald E. McNair Post-Baccalaureate Achievement Program. Their goal was to encourage low-income and first-generation college students, and students from historically underrepresented ethnic groups to expand their educational opportunities by enrolling in a Ph.D. program and ultimately pursue an academic career. This program is dedicated to the high standards of achievement inspired by Dr. McNair's life.

Source: mcnairscholars.com 
Table of Contents

List of 2015 PSU McNair Scholars

PSU McNair Scholars Program Staff

Women in Philosophy: A Qualitative Assessment of Experiences at the Undergraduate Level

By: Crystal Nicole Lilith Aymelek

Faculty Mentor: Dr. Veronica Dujon

The British-American Imperial Agenda in Iraq: the Oil and Railway line from Kirkuk to Haifa, 1920-1932

By: Melinda Cohoon

Faculty Mentor: Dr. Laura Robson

Come Out Come Out Wherever You Are: A Content Analysis of Homeless Transgender Youth in Social Service Literature

By: Shannon Crossley

Faculty Mentor: Dr. Ben Anderson-Nathe

The Media's Presentation of The Second Chance Act: Funding for Reentry Following Prison

By: Ailene Joyce Farkac

Faculty Mentor: Dr. Lee Shaker

Co-curriculum and ESL student success: A case study in an intensive English language program

By: James D. Mitchell

Faculty Mentor: Dr. Kimberley Brown

Role of metabolic shifts in protection from mutation damage:

Characterizing mitochondrial membrane potential in C. elegans gas-1 mutants

By: Lauren S. Muñoz-Tremblay

Faculty Mentor: Dr. Suzanne Estes

Characterization of the role that alternative ribonucleotide reductases play in restoring replication in the presence of hydroxyurea in Escherichia coli By: Michael Sadek

Faculty Mentor: Dr. Justin Courcelle 


\section{List of 2015 PSU McNair Scholars \& Mentors}

Jill Africa-Barnes

Crystal Aymelek-Christensen

Victor Benavides-Montes

Rachel Champaigne

Melinda Cohoon

Shannon Crossley

Charles Daniel

Ailene Farkac

Hernandez

Fardowsa Idris

Aubrey Limburg

Jenny Lor

Patricia Mansilla-Orihuela

Jillian Martin

Joyce McNair

James Mitchell

Emilio Molina

Lauren Munoz-Tremblay

Edgard Musafiri Mimo

Tan Nguyen

Esteban Rodriguez-Ariza

Griselda Velasco

Rachel Wall

Clayton Ward

Katie Whitaker

Kery White

Joanna Wolffe

Serena Worthington
Dr. Alma Trinidad

Dr. Veronica Dujon

Dr. Andrea Goforth

Dr. Kim Brown

Dr. Laura Robson

Dr. Ben Anderson-Nathe

Dr. Robert Roeser

Dr. Lee Shaker Matthew

Dr. Angela Coventry

Dr. Shankar Rananavare

Dr. Maura Kelly

Dr. Jose Padin

Dr. Shankar Rananavare

Dr. Carmen Ripolles

Dr. Jose Padin

Dr. Kim Brown

Dr. Jun Jiao

Dr. Suzanna Estes

Dr. Lemmy Meekisho

Dr. Marilyn Machiewicz

Dr. Jun Jiao

Dr. Suzanna Estes

Dr. Martin LaFrenz

Dr. Mark Blackmore

Dr. Hunter Shobe

Dr. Charles Webb

Dr. Susan Olson

Dr. Margaret Neal 
PSU McNair Scholars Program Staff \& Editorial Board

Dr. Toeutu Faaleava, Director, McNair Scholars Program

Dr. Jolina Kwong Caputo, Associate Director, McNair Scholars Program

Charles Daniel, Teaching Fellow

Melissa Pirie Cross, Teaching Fellow

Kristy Schepker, Teaching Fellow 
Portland State University McNair Research Journal 2015

Women in Philosophy:

A Qualitative Assessment of Experiences at the Undergraduate Level

By

Crystal Nicole Lilith Aymelek

Faculty Mentor:

Dr. Veronica Dujon

Citation: Aymelek, C. Women in Philosophy: A Qualitative Assessment of Experiences at the Undergraduate Level. Portland State University McNair Scholars Online Journal, Vol. 9, 2015. 


\section{Acknowledgements}

I would like to express my deepest gratitude to my McNair advisor, Dr. Veronica Dujon, for taking me on as a mentee, and for sharing her knowledge, wisdom, time and energy, without which this research would not have been possible. Working with Dr. Dujon has been an absolute pleasure; an experience I shall always remember as it has contributed immensely to my development not only as a scholar but as an individual.

I would also like to express deep gratitude to Dr. Jamie Ross, for her invaluable contribution in taking the lead in participant recruitment. And for her passion and encouragement which has contributed greatly to my sense of agency. Working with Dr. Ross has also been a memorable and great pleasure.

In addition, I want to thank the following professors for their assistance with participant recruitment: Dr. Joan Woolfrey, Dr. Sally Scholz, Dr. Hilda Lindemann, Dr. Debra Nails, Dr. Beata Stawarska, and Dr. Flo Leibowitz.

Further, I want to extend many thanks to Morgan Thompson, Toni Adleberg, Sam Sims, and Dr. Eddy Nahmias whose presentation at the 2013 annual meeting of the Society for Philosophy and Psychology inspired me to conduct this research, and whose survey inspired several of my interview questions.

To my participants: I thank you all from the bottom of my heart for offering your time and insight to this research. And above all, for your courage.

I would also like to thank the following individuals for their assistance and support on this project: Shirlee Geiger, Dr. Martha Bailey, Dr. Hannah Love, and Dr. Angela Coventry.

Next, I want to extend my gratitude to Dr. Toeutu Faaleava and Dr. Jolina Kwong Caputo for their hard work in advocating for first-generation college students, and for being such exemplary role models by demonstrating through their actions the value of integrity, empathy and humility.

To my 2014 McNair cohort: Thank you for the friendship, support and inspiration. You are brilliant.

Finally, I would like to thank my partner, Andrew X. Fleming, for his consistent support, love and all around amazingness throughout this project. Seni seviyorum, benim kral. 


\section{Abstract}

The underrepresentation of women in the field of philosophy has been a major concern for women in the discipline for at least the past ten years, and is increasingly gaining attention within academia. Current research at the undergraduate level suggests male and female enrollment occurs in relatively proportionate numbers in introductory philosophy courses but women's enrollment dramatically decreases with the progression to upper division courses (Paxton, Figdor \& Tiberius, 2012). To date, very little research has focused on the experiences of women philosophy majors at the undergraduate level. The present study conducted in-depth interviews with women who were either senior philosophy majors or those who recently received a bachelor's degree in philosophy in order to better understand what factors may contribute to the retention of women in the discipline. Our findings suggests that women with nontraditional gender schemas may be more likely to continue to take courses in philosophy. This finding may be mediated by the following factors: (a) exposure to philosophy prior to college; (b) having mentors irrespective of gender; (c) the presence of female faculty; (d) a supportive environment and; (e) a strong sense of agency as a student.

Keywords: Philosophy, Gender, Women, Marginalization, Cognitive Schemas 


\section{Introduction}

Current research suggests women continue to be underrepresented in traditionally male dominated fields (Monroe \& Chiu, 2010; Ward, 2008). To date, there has been a substantial increase in research on gender disparity in the STEM fields (i.e., science, technology, engineering and math). However, very little research has focused on the marginalization of women in philosophy (Hill, Corbett, \& St Rose, 2010; Maple \& Stage, 1991; Murphy, Steele, \& Gross, 2007; Stout, Dasgupta, Hunsinger, \& McManus, 2011). As a discipline in the humanities, philosophy stands out as an outlier with a profile similar to STEM fields. That is, the retention of women in philosophy remains among the lowest of all disciplines within the humanities_an area women typically gravitate toward (Healy 2009). Much of the extant research on gender parity in philosophy is focused at the graduate and faculty level (Haslanger, 2008; Van Camp, 2010). For example, it is estimated that women earned an average of 27 percent of doctoral degrees in philosophy from 1997 to 2012 with 21 percent among those currently employed teaching philosophy at the college level (Norlock, 2009; Van Camp, 2010). A survey of the top 51 doctoral programs in philosophy shows, on average, 23 percent of tenure or tenure track positions are held by women (Van Camp, 2010).

A recent study by Paxton, Figdor and Tiberius (2012) shows the most significant decrease in women in philosophy occurs at the undergraduate level. They found that men and women enroll in introductory philosophy courses in relatively proportionate numbers, but women's enrollment dramatically decreases among those who pursue philosophy as a major. 
Some research indicates that the lack of gender parity in philosophy may be attributed to factors synonymous to those found in STEM such as: gendered cognitive schemas, discrimination, stereotype threat, evaluation bias, and lack of female mentorship or visibility (Calhoun, 2009; Haslanger, 2008; Hill, Corbett, \& St Rose, 2010; Thompson, Adleberg, Sims, \& Nahmias, unpublished manuscript; Wylie, 2011). Given the research on women in the STEM fields, we think it plausible that a combination of all these elements are contributing to the marginalization of women in philosophy. However, as Paxton et al. (2012) point out, more empirical research is needed in order to accurately assess the factors responsible for the high attrition of female undergraduates in philosophy. Conversely, more research should examine what variables are responsible for the retention of women in the discipline. As such, this research aims to determine what factors may contribute to higher retention rates of women in philosophy. Our primary guiding hypothesis is that women who enter introductory philosophy courses with strong gendered schemas, that become confirmed, may be less likely to continue to take courses in philosophy, and by extension, women with non-traditional gender schemas may be more likely to continue to take courses in philosophy. The purpose of this study is to discover what, if any, commonalities female philosophy majors share in their backgrounds, experiences and perceptions that may shed light on the undergraduate career trajectories of female philosophy students.

\section{Conceptual Framework}

A schema is a cognitive network of associations that organize and guide an individual's perception. It is a process in which what is perceived is the product of an interaction between incoming information and stored information (Fiske \& Linville, 
1980). According to Bem (1981), gender schemas are mental templates that determine the expectation of gender roles in individuals according to biological sex and correlative social constructions. The development of gendered schemas begins in early childhood through socialization and varies by culture. Repeated observation or exposure to a particular gender schema may reinforce it as appropriate behavior to model (Perry, Davis-Blake, \& Kulik, 1994). People who share similar backgrounds may also adopt similar schemas while others establish alternative schemas based on unique experiences (Crockett, 1988).

Individuals who adhere to behavior according to social expectations of biological sex use more traditional schemas to define their identity and experience while those who deviate from this pattern use non-traditional schemas to define themselves (Bem, 1993). For example, a woman who identifies with more traditional or strong gender schemas may believe women are inherently nurturing and men inherently tough. By contrast, a woman who identifies with non-traditional schemas may view such attributes as existing on a continuum across all individuals regardless of sex. Individuals may develop new schemas when fundamental elements of their pre-existing schemas become modified, such as when they encounter new information that challenges or dispels current schemas (Perry et al., 1994).

Calhoun (2009) argues that the high attrition of females in philosophy may be attributed to gendered schemas made about philosophy prior to college (e.g. associating philosophy with masculinity). In other words, women may enter introductory philosophy courses primed to perceive philosophy from a gendered perspective and therefore may be more sensitive to perceiving information as gendered despite whether 
or not such instances occur frequently. Thus any discriminatory encounter would serve to confirm the schema as indicative of the field (Calhoun, 2009). For instance, women who associate philosophy with logic, and logic with math, may also believe the capacity for logic to be a masculine trait since math has traditionally been an area men gravitate toward and excel in. If this schema is confirmed upon their initial experience with a philosophy course, these women may conclude that they lack the capacity to develop skills in philosophy, and as a result, decide not to continue to take courses in it. Further, the absence of female faculty may serve to perpetuate the schema that philosophy is inherently a man's field. If more empirical evidence supported this hypothesis, it would be plausible then, based on the research of women in STEM, that pre-existing gender schemas, coupled with instances of discrimination may be perpetuated by stereotype threat, evaluation bias and lack of mentorship or female visibility, resulting in the low retention of women in the discipline.

\section{Methodology}

Relying on the work of Bem (1981) and Calhoun (2009), we developed a methodological approach that solicited interviews from female philosophy majors about their experiences as undergraduates. The interview questions were designed to draw out narratives about participant's experiences in ways that might reveal any gender schemas that may have influenced the interpretation of their experiences.

Further, this research builds on the work of Paxton et al. (2012)—which showed the highest attrition of women in philosophy occurs at the undergraduate level—by qualitatively assessing the experiences of female undergraduate philosophy majors in order to gain a better understanding of what factors may be responsible for the retention 
and attrition of women in the discipline. The goal of this project is to enhance understanding of this phenomenon from the perspective of the actual experiences of women in philosophy by exploring how they reflect on their careers as undergraduate students. By analyzing these reflections, this research hopes to shed light on the factors that led to these outcomes.

We conducted 11 interviews over a period of 4 weeks during the summer of 2014. The sample included female seniors majoring in philosophy, or those who recently earned a Bachelor's degree in it $(\mathrm{N}=11$, Age range: $18-31)$. Participants were recruited via email by convenience sampling at colleges and universities in the United States. Relying on an initial contact at Portland State University (PSU), we employed a snowball approach to enlist the assistance of professors. Some of these professors, in turn, reached out to other colleagues within PSU and to other universities to help identify potential participants. The purpose of this study was disclosed in the email. The number of participants accepted was based on those who responded and met the above criteria. All interviews were done by phone and audio recorded. The interviews took approximately 45 to 85 minutes, on average. The interview design was semistructured and open-ended to facilitate discussion of participant's experiences as philosophy majors as well as specific issues such as how they relate to the discipline of philosophy. All participants provided verbal and written informed consent as required by PSU Institutional Review Board. The interviews were recorded, transcribed and summarized. Emergent themes across interviews were identified and cross-checked in the final analysis. 


\section{Findings}

Out of 11 participants, three were first-generation college students and eight identified as Caucasian. The analysis of interviews revealed several themes that may be responsible for the retention of women undergraduates in the field of philosophy such as: (a) exposure to philosophy prior to college; (b) having mentors irrespective of gender; (c) the presence of female faculty; (d) a supportive environment and; (e) a strong sense of agency as a student. Furthermore, we found that participants exhibited elements of non-traditional gender schemas.

To begin, six out of 11 participants said they were exposed to philosophy prior to college. Of note, only two participants explicitly indicated that their experience with philosophy prior to college was positive. The most common form of exposure mentioned was in a high school course.

My high school actually offered a philosophy course in place of general humanities course. I don't think I had a formed idea about what philosophy was but it sounded like you addressed deeper questions and I thought that was cool so I took the class. (Participant 2)

In AP English my senior year we did a unit on existentialism and that really stuck with me. (Participant 4)

When I was in High school, I had a friend who arranged an independent study with a teacher, both ancient Greek and Greek philosophy, so I just sort of tagged along to that class and it was great. (Participant 7)

Among those who weren't exposed to philosophy prior to college only one participant said that she did not have a peer or mentor who influenced her decision to major in it. Out of the 11 participants, 10 said that their decision to major in philosophy 
was influenced by another person. The most common answer was a philosophy advisor or professor, followed by philosophy peers.

I talked to Dr. X, our philosophy Chair at X University and she encouraged me and made sure I could do it in that amount of time. No one really pushed me to do it but they said you're doing well, you might as well go for it. They were supportive. Steered me in the right direction. (Participant 3)

When I was first at $X$ State I was dating a guy who was a philosophy major and that had a huge effect on me. A couple of his friends were philosophy majors and we would all get together, and you know, hang out.

(Participant 9)

Participant's answers to the question regarding their favorite course in philosophy differed but in response to the question of which course they had the most difficulty with, the most frequently cited answer was modern philosophy.

Overall, participants said that they enjoyed philosophy because it encouraged critical thinking, it was challenging, helped them develop better reading and writing skills and fostered personal growth.

It's very challenging. It has forced me to examine what I believe and what I choose to stand up for and given me a more solid knowledge of who I am as a person. It has helped my critical thinking and writing skills immensely. It's helped me in talking to people. (Participant 4)

I love the perspective. I love the challenge. I love the fact that I never have to accept anything as fact. It's a discipline that's constantly evolving whereas other disciplines are a little more static and you learn what you learn and take the test. In philosophy there is always room for growth. I have incorporated that into my life personally. It's so refreshing that it's a subject that we can continually do research on, there are always new perspectives, always a challenge, always searching for something. (Participant 1) 
Most participants had at least two female philosophy professors during their careers as undergraduate philosophy students. More than half said that having a female presence in front of the class was influential but that they did not experience any differences between male and female faculty. All participants said it was important to have teachers of the same sex as role models, and six of the 11 participants added that having mentors, regardless of sex, was important.

Below, Participant 8 addresses the significance of having a female mentor in a male-dominated field.

Her name was Professor $X$ and she definitely, like seeing her as a strong female voice in a man's field was cool, like in science and philosophy. I feel like she kind of took me under her wing and I was always in her office hours. (Participant 8)

In the following two quotes, Participant 1 and Participant 3 discuss the importance of female visibility at the faculty level for retaining female students in philosophy. Of equal importance, both participants demonstrate an appreciation for mentorship regardless of sex.

I have always thought that was important just because when you see someone you can relate to that might attract you a little more to a class, or to a subject area. I have always thought that was important but I don't think it is necessarily the end all be all because there have been male professors who l've got along with famously and just because they are a man and I am a woman, you know they've been able to mentor me or encourage me in my studies. I think it is very important to have that bond with other female professors especially, I know on my campus there are not many female philosophy professors, so just to see other women in the discipline is really helpful because for some women it can keep them there but I don't think it is like the end all be all. I think sometimes it depends on who you connect with and maybe personality or interests, things like that. I think it's important at a first glance thing. (Participant 1)

I don't feel any more comfortable with men or women in a higher placement than me. It doesn't suddenly intimidate me but I can say that for 
others in my classes having a female teacher or advisor definitely helped them and they were much more comfortable with them. (Participant 3)

Below, Participant 2 highlights that a lack of female mentorship or visibility can negatively affect a female student's perception of what is possible for her in a given field. For example, a student may feel inadequate or that they lack a particular quality they believe necessary for success in philosophy. Participant 2 says this type of internalization may occur in a female student without her conscious awareness until she has an experience which illuminates it.

If this was a field where it was all men I don't think I would be able to get myself out of certain moments when I do get upset at like there's all these men thinking these great things. You know if you are talking to a bunch of professors and graduate students and they are all male, you wonder 'okay I want to go forward with this, I want to be able to be able to be a graduate student or professor but how? Like do I have to sacrifice something or is something missing in me or what do I have to do to be this thing which seems to be something that I am not.' That's hard to deal with. And I don't know that that is still explicit, that kind of thinking until you have a female professor or female graduate student because once you have that you realize that she was able to do it. She found a way and maybe there are different ways that she tried but I know concretely that this is something I can do. It doesn't have to reflect any deficiency in me from my being a woman or inability or something. (Participant 2)

In the subsequent quote, Participant 9 reflects on her experience as a female in academia. She says she previously felt pressured to repress her ideas and opinions in the classroom. She attributes the pressure she experienced to her perception of the social expectations surrounding how women ought to behave in an academic setting. Moreover, she says she adhered to these expectations despite that they conflicted with her personality.

Honestly I think, when I reflect back on feeling uncomfortable in sharing my opinions, I think, and to be honest, this makes me sad to say, but, 
being a girl, I think I have always I think been subconsciously aware of this pressure to not speak up too loud, you know, and not rock the boat, and that's partially, I mean, that's kind of my family, and my culture, and all these different factors. That was a big thing with it, was, well, I don't want to challenge the boy's ideas. That's terrible but I thought of it like a fifties, just totally oppressive attitude of women, to kind of be docile and you know, whatever. I just don't want to cause too much trouble. My personality isn't like that but I definitely felt that pressure at school, and in class, and so, that was a factor, was being a female and feeling like I wasn't, for whatever reason, qualified enough to share my opinion or to speak out when I disagreed, or something like that. (Participant 9)

Despite being in an environment where they were a minority, most participants said they felt comfortable expressing their ideas and opinions in class but noticed other women did not participate as much.

I think definitely there is a big gap in participation between male and female students in philosophy, by far, I would say. It seems like sometimes male voices can be louder and intimidating. There is usually like 3 males in the class that have these dominant voices and don't let other people participate as much. I think I have to make a conscious effort sometimes to think I can participate too, it's not just them. It's maybe $20 \%$ of the time a female student is asking a question and $80 \%$ of the time it's a male. It's pretty off. (Participant 8 )

I had one class last year, Epistemology and there were quite a few other vocal females, probably four or five. But that was surprising. I can recall where I was like 'wow, it's me and these five guys, who are discussing Kant, and that's it.' Everybody else, I mean there are other girls in the class but they were not participating at all. (Participant 9)

In the following quote, Participant 9 states that while she is comfortable being a vocal participant in class; that has not always been the case. She says it wasn't until she became aware that her traditional notions of what constitutes appropriate behavior for a woman in an academic setting were adversely affecting her academic performance that she decided to be her own agent of change-suggesting an evolution in her gender schema. 
I do now feel comfortable sharing my opinions and my thoughts, but that has not always been true... . I think the biggest change was really, like my own process, figuring out who I was as a person, and that also happened outside of school. A lot of that was seeing that pattern, that I described where I didn't feel I could be vocal about my opinion, or too smart, or, you know, all of these things, because I was supposed to be a girl. And that was a big generalization. That has really actively held me back in my academics. When I came back to school I was like 'Okay, we're done with that. No more of that.' That's, that's you know, one of those things where once I realized that I was living under that pattern and perpetuating a pattern by my own habits, I was like 'oh my god, that is like the most absurd, intellectually it is the most absurd thing I have ever heard.' But for whatever reason, I was emotionally kind of perpetuating that dichotomy: male/female academic dichotomy. So, that was a big disadvantage, I think. (Participant 9)

Finally, more than half of participants reported that they felt a strong sense of agency as a student prior to majoring in philosophy.

Once I found my footing and really ran with it, I had a lot of confidence in myself because basically whatever class I was in, some of them were harder and some easier courses but l've always excelled in whatever I put my mind to. I always had a lot of confidence in myself. (Participant 3 )

I think going in, my sense of doing academic work because I come from an academic family. Once you grow up in a setting like that it's like 'obviously you'll go to college, obviously you'll go to a graduate program, and obviously you'll get all A's. What else would you be doing?' When you go in with that assumption you're already operating from a really privileged space in terms of how you learned about yourself in an education system... . I went in thinking of course l'll do this well because that's what I have to do in an academic setting... . (Participant 10)

\section{Analysis and Discussion}

We hypothesized that women who enter introductory philosophy courses with traditional gender schemas, that become confirmed, may be less likely to continue to take courses in philosophy, and by extension, women with non-traditional gender schemas may be more likely to continue to take courses in it. We found that participants 
who were selected for persistence in their major demonstrated elements of nontraditional gender schemas. For instance, participants showed an appreciation for mentorship irrespective of gender. Women with non-traditional gender schemas tend to identify with mentors according to similarity in attributes as opposed to gender (Markus, 1977; Wood, 1989). Participants also showed a willingness to actively participate and express ideas in an environment where they were the minority. Individuals at risk for stereotype threat (i.e., minorities) are often overly concerned with performance in a particular domain and thus will refrain from participation in order to avoid confirming the stereotype associated with that domain (Aronson, Quinn, \& Spencer, 1998). Further, participants sought and enjoyed philosophy despite that they said it was challenging. For example, many participants said that modern philosophy was the most difficult course they took but that they enjoyed it a great deal. Challenge-seeking is a characteristic traditionally associated with masculinity (Green \& Foster, 1986). Finally, many participants were interested in or pursued other majors or minors in STEM fields, or disciplines that rely heavily on math, such as economics.

In reflecting on the theoretical framework that informed this research, and considering the evidence collected, the following diagram maps out what the analysis seems to suggest is occurring. In this conceptual understanding, we propose the internal factors traditional gender schemas and non-traditional gender schemas may each be mediated by the external factors support or no support resulting in attrition and retention. We define support as any assistance or encouragement experienced by students that positively influences the participation and retention of female students in philosophy. 


\section{Diagram 1}

\section{Pathways of Retention and Attrition}

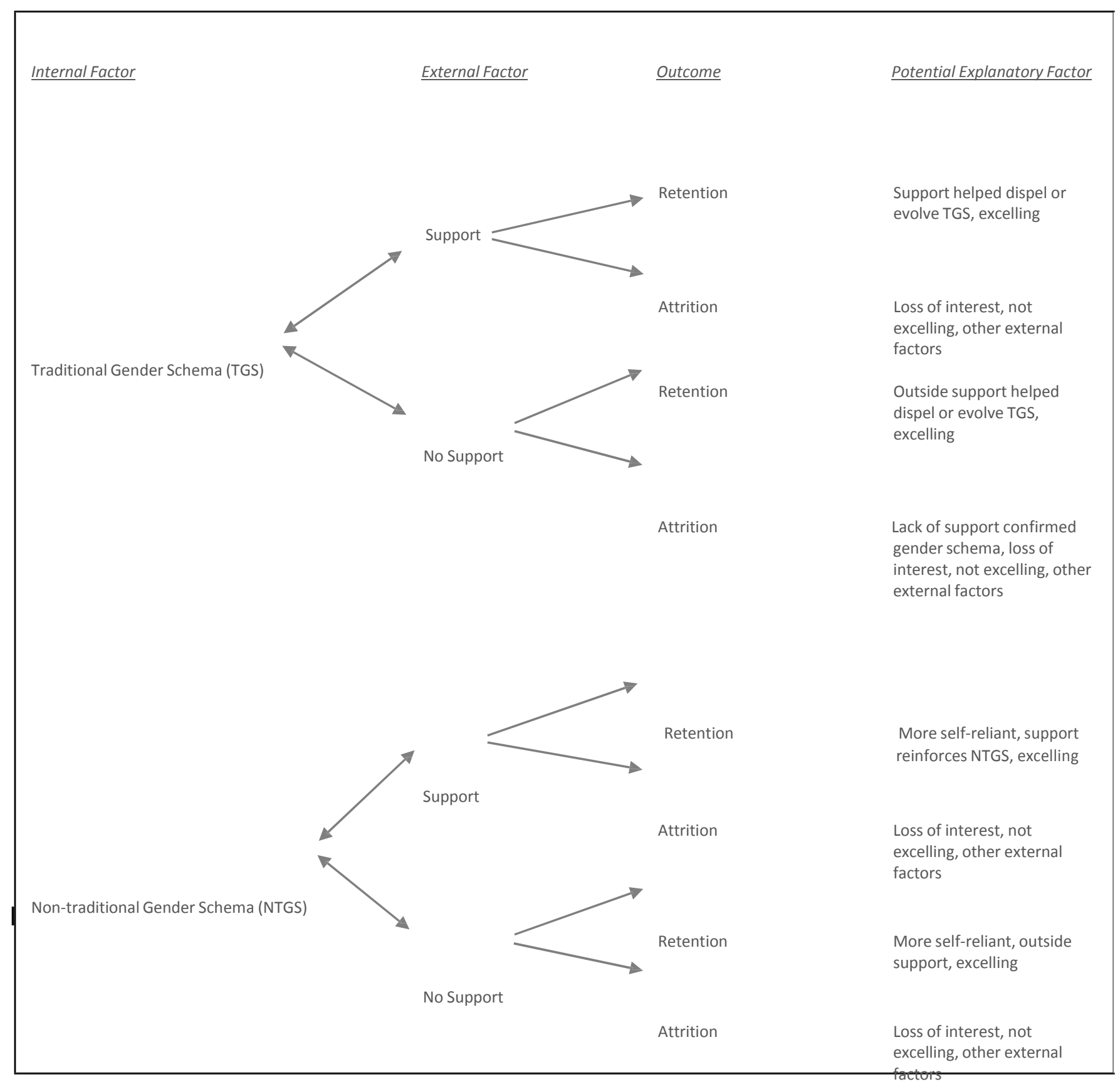

In the first path of the diagram we propose traditional gender schemas as the internal factor and support as the external factor resulting in retention of the female 
student in philosophy. A potential explanation for this outcome is that support may help 
dispel or evolve traditional gender schemas women have about philosophy by altering their perception of it. For example, support may prompt a female student with more traditional gender schemas to see that the capacity to excel in philosophy is relative to the individual and not based according to sex-linked characteristics.

The first path in the second half of the diagram maps out our findings. That is, participants who were selected for persistence in philosophy demonstrated elements of non-traditional gender schemas. Furthermore, participants indicated several factors that may have contributed to their success in philosophy, collectively referred to here as support.

Our findings suggest a relation between non-traditional gender schemas and support in the retention of female students in philosophy. Due to limitations of time and of resources, such as access to a wider range of philosophy departments, we were unable to identify a larger sample of participants. As such, future research should seek a larger sample in order to further examine the effects of support in the recruitment and retention of female undergraduates in philosophy.

\section{Conclusion}

Our findings suggests that women with non-traditional gender schemas may be more likely to continue to take courses in philosophy. This finding may be mediated by the following factors: (a) exposure to philosophy prior to college; (b) having mentors irrespective of gender; (c) the presence of female faculty; (d) being in a supportive environment and; (e) a strong sense of agency as a student. Future research, perhaps 
in the form of a survey, could focus on establishing how widespread these findings might be. 


\section{References}

Aronson, J., Quinn, D. M., \& Spencer, S. J. (1998). Stereotype threat and the academic underperformance of minorities and women.

Bem, S. L. (1981). Gender schema theory: A cognitive account of sex typing.

Psychological review, 88(4), 354. http://dx.doi.org/10.1037/0033-295X.88.4.354

Bem, S. L. (1993). The lenses of gender: Transforming the debate on sexual inequality. New Haven: Yale University Press.

Calhoun, C. (2009). The undergraduate pipeline problem. Hypatia, 24(2), 216-223. http://dx.doi.org/10.1111/j.1527-2001.2009.01040.x

Crockett, W. H. (1988). Schemas, affect, and communication. In L. Donohew, H. Sypher, \& E. Higgins (Eds.), Communication, social cognition, and affect. Hillsdale, NJ: Lawrence Erlbaum Association

Fiske, S. T., \& Linville, P. W. (1980). What does the schema concept buy us? Personality and Social Psychology Bulletin, 6, 543-557. http://dx.doi.org/10.1177/014616728064006

Green, L., \& Foster, D. (1986). Classroom intrinsic motivation: Effects of scholastic level, teacher orientation, and gender. The Journal of Educational Research, 34-39. http://dx.doi.org/10.1080/00220671.1986.10885718

Haslanger, S. (2008). Changing the ideology and culture of philosophy: Not by reason (alone). Hypatia, 23(2), 210-223. http://dx.doi.org/10.1111/j.1527-2001.2008.tb01195.x

Healy, Kieran. "Percentage of Ph.Ds awarded in the U.S. to Women in 2009". Accessed July 29, 2014. http://kieranhealy.org/files/misc/phil-by-division.pdf

Hill, C., Corbett, C., \& St Rose, A. (2010). Why So Few? Women in Science, Technology, Engineering, and Mathematics. American Association of University Women. 1111 Sixteenth Street NW, Washington, DC 20036.

Maple, S. A., \& Stage, F. K. (1991). Influences on the choice of math/science major by gender and ethnicity. American Educational Research Journal, 28(1), 37-60 http://dx.doi.org/10.3102/00028312028001037

Markus, H. (1977). Self-schemata and processing information about the self. Journal of personality and social psychology, 35(2), 63. http://dx.doi.org/10.1037/0022$\underline{3514.35 .2 .63}$ 
Monroe, K. R., \& Chiu, W. F. (2010). Gender equality in the academy: The pipeline problem. PS: Political Science \& Politics, 43(02), 303-308.

http://dx.doi.org/10.1017/s104909651000017x

Murphy, M. C., Steele, C. M., \& Gross, J. J. (2007). Signaling threat how situational cues affect women in math, science, and engineering settings. Psychological Science, 18(10), 879-885. http://dx.doi.org/10.1111/j.1467-9280.2007.01995.x

Paxton, M., Figdor, C., \& Tiberius, V. (2012). Quantifying the gender gap: An empirical study of the underrepresentation of women in philosophy. Hypatia, 27(4), 949-957. http://dx.doi.org/10.1111/j.1527-2001.2012.01306.x

Perry, E. L., Davis-Blake, A., \& Kulik, C. T. (1994). Explaining gender-based selection decisions: A synthesis of contextual and cognitive approaches. Academy of Management Review, 19(4), 786-820. http://dx.doi.org/10.2307/258745 / http://dx.doi.org/10.5465/AMR.1994.9412190219

Stout, J. G., Dasgupta, N., Hunsinger, M., \& McManus, M. A. (2011). STEMing the tide: using ingroup experts to inoculate women's self-concept in science, technology, engineering, and mathematics (STEM). Journal of personality and social psychology, 100(2), 255. http://dx.doi.org/10.1037/a0021385

Thompson, M., Adleberg, T., Sims, S., \& Nahmias, E. (unpublished manuscript). Why do women leave philosophy? Surveying students at the introductory level.

Van Camp, J. (2010). Tenured/tenure-track faculty women at 98 US doctoral programs in philosophy. http://www.csulb.edu/ jvancamp/doctoral 2004.html (updated February 3, 2014; accessed February 16, 2014).

Ward, L. (2008). Female faculty in male-dominated fields: Law, medicine, and engineering. New Directions for Higher Education, 2008(143), 63-72.

http://dx.doi.org/10.1002/he.314

Wood, J. V. (1989). Theory and research concerning social comparisons of personal attributes. Psychological bulletin, 106(2), 231. http://dx.doi.org/10.1037/00332909.106.2.231

Wylie, A. (2011). Women in Philosophy: The Costs of Exclusion-Editor's Introduction. Hypatia, 26(2), 374-382. http://dx.doi.org/10.1111/j.1527-2001.2011.01180.x 


\section{Appendix}

1. Were you exposed to philosophy prior to college?

a. What did you think about philosophy prior to majoring in it?

2. When did you decide to major/minor in philosophy?

a. Did you know you wanted to major/minor in philosophy before you began college?

b. What factors do you think contributed to your interest in philosophy prior to attending college?

3. Why did you decide to major/minor in philosophy?

a. Was there anyone who influenced your decision to major in philosophy?

b. What other subjects are you majoring/minoring in?

c. What were some other subjects that you considered majoring in? Why?

4. In your opinion, what is a philosopher?

a. What qualities or characteristics make a good philosopher?

5. What was your favorite class in philosophy?

a. Why did you like this class?

b. What did you appreciate about it?

c. How was your experience in it different from that of other classes?

6. What class or classes did you have the most difficulty with?

a. Why?

7. Who is your favorite Philosopher?

a. Why?

8. Which female philosophers/authors have you been exposed to throughout your study of philosophy?

a. How have these philosophers influenced you?

9. What do you like most about philosophy?

10. What area of philosophy are you most interested in?

a. Why?

11. How many female philosophy professors have you had?

a. How has this influenced your study of philosophy?

b. Have you noticed any differences in your experience with male and female faculty?

c. Would you like to talk about this?

12. What qualities make a good philosophy professor?

a. Why?

13. How important do you think it is to have teachers of the same sex as role models?

14. How important do you think it is for women to be involved in philosophy? 
15. Do you have any female friends or acquaintances that were initially interested in pursuing philosophy as a major or minor but decided not to?

a. If so, why?

16. Do you have any friends or acquaintances in classes who have dropped out of philosophy classes?

a. If so, why?

17. What did you expect to gain by majoring or minoring in philosophy?

a. How has philosophy met or not met those expectations?

18. Do you feel you had a strong sense of efficacy prior to majoring in philosophy?

19. Do you feel comfortable expressing your ideas and opinions in class?

a. Was there ever a time when you felt uncomfortable expressing your ideas/opinions in philosophy classes?

b. If so, why

c. What factors do you think made you more or less comfortable?

d. Did other women in your classes participate regularly in discussion?

20. Do you think that anyone has the capacity to succeed in philosophy?

a. If so, Why?

b. If not, Why not?

21. What is the proportion of female versus male students in your philosophy classes?

a. How, if at all, has this affected your classroom experience?

22. How do you feel that your male peers responded to and/or treated your thoughts and ideas?

23. Do you feel that gender is an issue in philosophy?

a. If so, why?

b. If not, why not?

24. Do you intend to pursue a graduate degree?

a. If so, in what field?

b. If philosophy, what area?

c. If not philosophy, why?

d. Do you have any concerns about pursuing a graduate degree in philosophy?

25. If you could offer advice to any females interested in pursuing philosophy as a major or minor, what would you say?

26. Are you happy that you majored in Philosophy?

a. What do you intend to do with your degree?

27. What is the highest level of education your parents, guardians or caregivers completed?

a. What degrees? 
b. How many degrees?

c. In what area of expertise?

28. Are either of your parents, guardians or caregivers a professional philosopher?

a. How has this influenced your interest in philosophy?

29. Is anyone in your family a professional philosopher?

a. How has this person influenced your interest in philosophy?

30 . What race or ethnicity do you identify with?

31. Age Bracket: (18 to 24 ) (25 to 31 ) (32 to 38 ) (39 to 45 ) (45 to 51) (52 and older)

32. Is there anything else that you think I should know or that you want to add? 


\section{Informed Consent}

\section{Dear Participant:}

My name is Crystal Aymelek and I am an undergraduate psychology student at Portland State University. I am working with Dr. Veronica Dujon on a study focused on the experiences of undergraduate women in philosophy. I will be conducting my research at Portland State and would like to invite you to participate.

You are being asked to take part because you are a student who has recently earned a bachelor's degree in philosophy or is currently majoring in philosophy. As part of the study, I am interested in the female perceptions and experiences with philosophy. The information I collect will help to better understand why women choose philosophy as a major. If you decide to participate, you will be asked to share your perspectives and experiences with me in an interview. During the interview you will be asked questions about your experiences with philosophy as well as some questions about your family background. You may choose not to answer any question, and you may choose to end the interview at any time should you wish to do so, without any repercussions to you. The interview will take place at a location of your choice that is comfortable and convenient for you. It will be audio recorded and should take between 30 to 50 minutes to complete.

It is not anticipated that there are any risks involved with your participation. You may or may not receive any direct benefit from taking part in this study, but this research may help to increase knowledge that may be useful for understanding how women relate to philosophy.

Any information that is obtained in connection with this study and that can be linked to you or your identity will be kept confidential. Pseudonyms will be used to refer to participants who take part in the interview. Participation is entirely voluntary. Your decision to participate or not to participate in this study will in no way affect your relationship with the researcher or your affiliated educational institution.

If you have concerns or problems about your participation in this study or your rights as a research subject, please contact the Human Subjects Research Review Committee, Office of Research and Strategic Partnerships, Portland State University, P.O. Box 751, Portland, Oregon 97207, 503.725.2227. If you have any questions, or would like to speak to the researchers, please contact Dr. Veronica Dujon at 503.725.8503 or by email dujonv@pdx.edu and/or Crystal Aymelek at 503.820 .9870 or by email ccrystal@pdx.edu.

Your signature indicates that you have read and understood the above information and agree to take part in the study. Please understand that you may withdraw your consent at any time without penalty, and that, by signing, you are not waiving any legal claims, rights or remedies. The researcher will provide you with a copy of this form for your own records.

Signature

Date 
The British-American Imperial Agenda in Iraq: the Oil and Railway line from Kirkuk to Haifa, 1920-1932

\author{
by \\ Melinda Cohoon
}

Faculty Mentor:

Associate Professor Laura Robson

Cohoon, M. The British-American Imperial Agenda in Iraq: the Oil and Railway line from Kirkuk to Haifa, 1920-1932. Portland State University McNair Scholars Online Journal, Vol. 9, 2015. 


\section{Introduction}

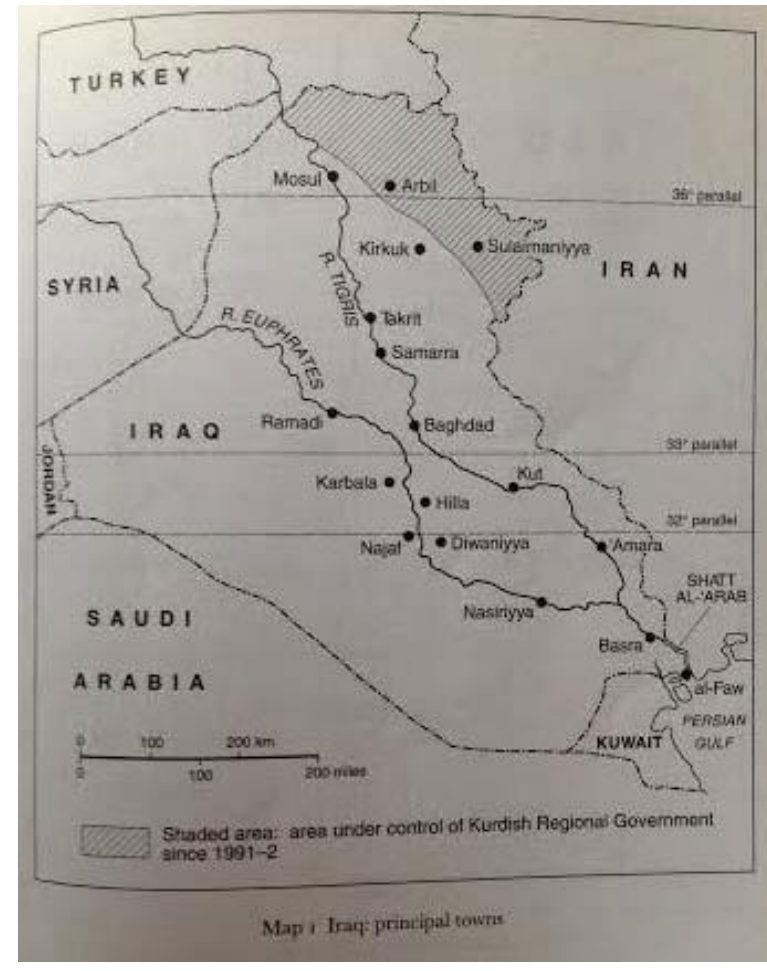

During the 1920s, British-American oil and railway developers in the former province of Mosul created burgeoning ethnic divides. Many of the people in the Mosul region disagreed with the province coming under the direct rule of Baghdad as they were discontented with centralization. Yet, they lacked a sense of a nationalist identity. The British considered mineral exploitation more imperative than these anti-centralization sentiments. As a consequence, the British imperial power disregarded the ethnic diversity of Mosul and their objections to becoming part of a united Iraq. This is evident when examining actions of European consortium Anglo-Persian Oil Company (APOC). Before the finalization of Mosul's inclusion in Iraq, APOC surveyed a pipeline and railway from Kirkuk to Haifa in 1922. Mosul's inclusion in Iraq, where the town of Kirkuk lies, occurred in 1926.

Figure 1: Map of Iraq. ${ }^{1}$

Mineral resources in Iraq also engendered a dispute between British and American oil ambitions. British oil hegemony assuaged the quarrel over oil resources, because U.S. interests determined that aligning with the British imperial power would amount to them obtaining mineral rights. Furthermore, British authority and U.S. ambitions for Iraqi oil coincided with railway expansion, and they were attentive toward the potential Kirkuk-Haifa oil and railway lines. Obtaining mineral and railway concessions was a priority for the U.S. State Department. Nevertheless, the British sought to maintain their predominance over Iraqi oil. In 1925, U.S. Standard Oil Company bought part ownership of the Turkish Petroleum Company (TPC). TPC was the main purveyor of oil after the 1925 Kirkuk-Haifa oil and railway concession, an agreement officially signed between the Iraqi government and TPC in 1928. British and American consortiums such as APOC and TPC were a factor in the Mosul question. Consortium hegemony over mineral resources and railway infrastructure were the dominant themes throughout U.S. correspondence during the $1920 \mathrm{~s}$.

\section{Historiography of Iraq: Oil and Railways}

Historical scholars of 1920s Iraq argue that the premise for the founding of the Iraqi state was based on oil: therein lies the dichotomies of the historical scholarship. One argument leans toward how oil influenced ethnic divides, while the other argument does not consider the oil question and insinuates that when Iraq formed, the British took ethnic heterogeneity into account. Another explanation suggests that oil was paramount to the British agenda in Iraq,

\footnotetext{
${ }^{1}$ Charles Tripp, A History of Iraq (Cambridge: Cambridge University Press, 2007), xix.
} 
while the British all together disregarded the issue of ethnic heterogeneity when creating the Iraqi state. However, the scholarship lacks a concrete analysis on the connection between oil and railways and how these issues brought to fruition conflict amongst the heterogeneous population of Mosul. Iraqi oil and railways were capitulations granted by the Iraqi government under the discretion of the British Iraqi Administration to British-American oil consortiums, while the British government ignored the impact these capitulations were to have on the heterogeneous population. Before Iraq's creation, the area was made up of semi-autonomous provinces where ethnic lines were blurred. ${ }^{2}$ The population in Mosul aligned themselves with more than one ethnicity, and therefore, uniting Mosul, Basra and Baghdad into a single entity led to an "emerging fault-line" amongst the heterogeneous population. ${ }^{3}$ Proposed oil and railway lines that cut through the Mosul region was at the expense of Mosul's autonomy. Mosul came under Iraq's wing because of an insistence for exploiting its potential mineral resources.

Peter Sluglett's and William Stivers' scholarship represent earlier historical analyses of Iraq and oil, while demonstrating the importance of oil to the British. However, their scholarship does not establish the connection between ethnic heterogeneity and the Mosul question. Peter Sluglett's Britain in Iraq: Contriving King and Country ( $2^{\text {nd }}$ ed., 2007), whose first edition was written in the 1970's, and William Stivers' Supremacy and Oil: Iraq, Turkey, and the AngloAmerican Order, 1918-1930 (1982) address the relationship between the British and the oil companies who wanted concessionary power in Iraq. According to these scholars, Mosul's inclusion into the Iraqi state was a result of oil ambitions. Sluglett uses primary source documentation from the British Foreign Office, Air Ministry, and Colonial office records, including private and publicized documents. Continuing the tradition of using public and private governmental documents, Stivers' scholarship uses the Foreign Office Political Files, but he also includes primary sources pertaining to U.S. foreign relations, several U.S. edited document collections, and personal accounts.

The difference between Sluglett's and Stivers' arguments lie in their elucidation of British and American oil ambitions. For instance, Sluglett argues that the British authorities set up the Iraqi government in a way that was to best serve British interests, with concerns for "its communications with India, the Empire air route, and the protection of the Persian and Iraqi oilfields." ${ }^{4}$ Like Sluglett, Stivers explains British involvement in Iraq as a strategic move in maintaining control over India as well as Iraqi oil. ${ }^{5}$ However, Stivers argues that British control over Iraq served American interests because stability in the region meant tranquil conditions for U.S. investment and trade. ${ }^{6}$ Charles Tripp's History of Iraq (2000) and Toby Dodge's Inventing Iraq: The Failure of Nation Building and a History Denied provides a broader context for the formation of the Iraqi state. Tripp argues that the British owned a substantial stake of TPC, and therefore, these British authorities saw Mosul as an opportunity for revenue and the possibility of removing Iraqi part-ownership of oil concessions. ${ }^{7}$ Tripp, Stivers, and Sluglett mainly use British government documents in their historical work, while other scholarship uses

\footnotetext{
${ }^{2}$ Arbella Bet-Shlimon, "Group Identities, Oil, and the Political Domain of Kirkuk: A Historical Perspective," in Journal of Urban History, vol. 38: 2012, 916, accessed: February 10, 2014. DOI: 10.1177/0096144212449143

${ }^{3}$ Ibid, 915.

${ }^{4}$ Peter Sluglett, Britain in Iraq: Contriving King and Country (New York: Columbia University Press, 2007$)$, 6/7.

${ }^{5}$ William Stivers, Supremacy and Oil: Iraq, Turkey, and the Anglo-American World Order, 1918-1930 (Ithaca and London: Cornell University Press, 1982), 18.

${ }^{6}$ Ibid, 192.

7 Tripp, A History of Iraq, 60.
} 
a diverse subset of primary sources ranging from newspaper articles to poetry in addition to government correspondence.

While Stivers' and Sluglett's main goal throughout their scholarship is to show British and U.S. imperial concerns for oil, another theme throughout the literature establishes how imperial mineral ambitions affected the ethnic heterogeneous population of Iraq. Arbella Bet-Shlimon in her work "Group Identities, Oil, and the Local Political Domain in Kirkuk: A Historical Perspective" (2012) argues that to consider Kirkuk's oil as merely a commodity denies the historical realities that oil produced for the population such as oil urbanization, which "created ethnic identities and rivalries." ${ }^{8}$ Meanwhile, Guiditta Fontana's "Creating Nations, Establishing States: Ethno-Religious Heterogeneity and the British Creation of Iraq in 1919-23" (2010) argues that "establishment of nation-states was complicated by the existence of a variety of minorities and rival ethno-religious groups," and that "British policymakers took these factors into account in 1919-20." 9 Though Guiditta's work does not consider oil, her view is starkly contrasted to Bet-Shlimon's scholarship when concerning the effect of the British on Iraq. Guiditta states that there were pre-existing ethnic rivalries throughout Iraq, while Bet-Shlimon implicates that oil ambitions created the ethnic conflict within Kirkuk. Both scholars use Colonial office records, and other governmental documents; however, Bet-Shlimon uses poetry to accentuate the tumultuousness of oil urbanism during the 1950's for Kirkukis.

One of the main themes throughout the scholarship on Iraq focuses on ethnic identities and rivalries, and how oil and the British were factors in creating new issues after the formation of Iraq. Another dichotomy within the literature concerns itself solely with the British and U.S. oil interests in Iraq. The gap appears to lie within uniting both U.S. and British oil interests relative to the central issue to the Mosul question of ethnic divides, while also correlating oil and railways as a unifying factor of interest for the imperial ambitions. The literature on railways is inherently scarce, as the most recent scholarship on 1920s Iraqi railways is Edward Mead Earle's Turkey, the Great Powers, and the Bagdad Railway: A Study in Imperialism (1923), and other historical scholarship tends to focus on the Baghdad railway prior to the creation of Iraq such as Sean McMeekin's The Berlin-Baghdad Express: the Ottoman Empire and Germany's Bid for World Power (2010). Throughout this work, it will be argued that the BritishAmerican concern for oil and railways created burgeoning ethnic rivalries in the Mosul region during the interwar period, and that these imperial powers were backing Anglo-Persian Oil Company and Turkish Petroleum Company without concern for the ramifications of having Mosul governed by a Sunni Arab elite in Baghdad.

\section{Iraqi Railways and the Anglo-Persian Oil Company: General Imperial Interests and its Relationship with the Iraqi Government}

During the 1920s, British imperial interests encompassed Iraqi railway infrastructure and oil resources. While the British were in charge of the Iraqi mandate, the U.S. placed consulates in Baghdad to build a cordial relationship with the Iraqi government. The U.S. consulates of

\footnotetext{
${ }^{8}$ Bet-Shlimon, "Group Identities, Oil, and the Political Domain of Kirkuk: A Historical Perspective," 915.

${ }^{9}$ Guiditta Fontana, "Creating Nations, Establishing States: Ethno-Religious Heterogeneity and the British Creation of Iraq in 1919-23," in Middle Eastern Studies, 46:1, 2, (Feb 12, 2010), accessed February 10, 2014, DOI: $10.1080 / 00263200902760535$.
} 
Baghdad sent correspondence to the Department of State commenting on British affairs, with an opportunistic eye for U.S. investment for Iraqi oil and railways. Prior to the Iraqi mandate, American commercial enterprises had limited contact with Ottoman provinces: dates and licorice root were their main imports, while the main export was oil into Iraq by Standard Oil Company of New York. ${ }^{10}$ By the 1920s, the Iraqi oil question concerned the U.S. Standard Oil Company (Socony) and the U.S. State Department. A mutual attraction to oil linked the U.S. State Department and Standard Oil together for "profit-seeking ambitions."11

However, British imperial ambitions comprised of more than Iraqi oil and railway infrastructure, because different philosophies for Middle Eastern policy were dependent on the division of authority. The Colonial Office, Foreign Office, War Office and India office, were each given a piece of power, which "ensured that visions for the territorial and political organization of the occupied areas became a source of bureaucratic infighting." 12 On the other hand, the premise for British post-war policy on Middle Eastern petroleum was a desire for mineral resource hegemony. ${ }^{13}$ Once the British received the Iraqi mandate, a major shift in the political realities of the inhabitants accumulated into hostility that led to the June 1920 revolt. ${ }^{14}$ Because of the insurgents' destruction of the railway lines, it was necessary to reconstruct the line and shut down the route between Basra and Baghdad. The stability of the railway system throughout Iraq required a grant to replace unsafe timber bridges with permanent lines. ${ }^{15}$ This resulted in an economic deficit for British authority between 1921 and 1922, due to railway infrastructural development and the high cost of oil per ton. According to the Foreign Office report by the High Commissioner on the Finances, Administration and Condition of Iraq, the requirement necessary for capital investment was to ensure that the railways up to a "moderate standard of equipment and to provide access to Karbala and Najaf." Otherwise, the railways were not up to a standard of use for achieving their commercial potentialities. ${ }^{16}$

As a public utility, the Iraqi railways were unprofitable; therefore, the British considered potential buyers. Correspondence between the American Consulate of Baghdad and the U.S. Department of State pondered on whether the Iraqi government was to run the Mesopotamian railways. The Iraqi railway question was due to the British Disposal and Liquidation Commission contemplating the transfer of the Iraqi railways to the Iraqi government, in 1922. Furthermore, the commission also reviewed the possibility of permitting the Iraqi government to sell or lease railway properties to private companies. ${ }^{17}$ However, the British determined it may prove more beneficial to concede railway and oil to the Anglo-Persian Oil Company (APOC) than to sell the railways to the Iraqi government. That year, APOC took over the Hillah to Basra rail line, to use the line's materials for constructing a railway from Tikrit to Mosul by

\footnotetext{
10 Stivers, Supremacy and Oil, 108.

${ }^{11}$ Ibid, 113.

${ }^{12}$ Fontana, "Creating Nations, Establishing States: Ethno-Religious Heterogeneity and the British Creation of Iraq in 1919$23, " 2$.

13 Sluglett, Britain in Iraq, 68/69.

14 Tripp, A History of Iraq, 43.

${ }^{15}$ Foreign Office, "Report by His Majesty's High Commissioner on the Finances, Administration and Condition of the 'Iraq for the period from $1^{\text {st }}$ October 1920 and 31 ${ }^{\text {st }}$ March 1922 [FO 371/8998]," in Iraq Administration Reports, 1914-1932, vol. 7, 1920-1924, ed. Robert L. Jarman (Melksham and Oxford: Redwood Press Ltd. and Green Street Bindery, 1992 ), 64/65.

${ }^{16}$ Ibid, 65.

17 NAUS, RG59, M1370, reel 26, 890g.77, "Telegram received," Harvey to the Secretary of State, Washington, February 11 , 1922./ NAUS, RG59, M1370, reel 26, 890g.77/oug, "Telegram Sent," Fletcher from the Department of State of Washington to the American Consulate of Baghdad, February 14, 1922; 1.
} 
way of Kirkuk and Erbil. ${ }^{18}$ Heading the prospect was Sir AT Wilson, former British civil commissioner of Baghdad from 1918-1920 and Resident Manager of APOC, who in 1922 was "looking over the survey of the proposed railway and pipeline to the Mediterranean."19 Nevertheless, the Iraqi government still hoped to purchase the railways.

In February 1923, an interview with the Minister of Public Works Yasin Pasha Al-Hashimi and the American Consulate of Baghdad revealed that "the British were asking $31 / 2$ millions sterling for the railways which consist of 580 miles, but [al-Hashimi] thought this amount exorbitant, and opposed buying at these figures." 20 The Iraqi government could only afford to replace the existing railways but could not afford to purchase the 580 miles of railway at war prices. Though the British government in May 1923 transferred provisionally the management of the railways to the Iraqi government's Minister of Communications and Works, the British relied on other sources for concessionary power, such as APOC, over the Mesopotamian railways. ${ }^{21}$ Any power the Iraqi government had over the Mesopotamian railways was inherently limited.

The Iraqi government's Minister of Public Works al-Hashimi was, however, in an unpopular position with the British. Interestingly, al-Hashimi took advantage of his position to obtain both land and use laws to validate such transactions as well as to enable tax exemption for his behest. ${ }^{22}$ U.S. capital investment in railways and oil were an interest of al-Hashimi, which the American consulate of Baghdad stated: "I told him that if American capital participated in the exploitation of oil, I saw no reason why it should not be available for other necessary developments, as soon as the status of the country was definitely determined and there is reasonable hope of security." 23 al-Hashimi thought that TPC's claims to oil was weak and disfavored its ratification, while indicating that the Iraqi government was "opposed to giving any concession to the Anglo Persian Oil Company if another can be found [...]."24

The crux of al-Hashimi's argument established a distaste for the control over the railway system and its correlative, oil, for both APOC and TPC. In 1922, the American consulate suspected that APOC was to receive control over the Mesopotamian railways, as it was certain that "the so-called Government of Iraq will not operate them." ${ }^{25}$ This perception came from the apparent connection of APOC to the 1914 D'Arcy concession that gave APOC the ability to build oil wells throughout the Ottoman Empire's territories. ${ }^{26}$ APOC obtained its own route in

\footnotetext{
18 NAUS RG59, M1370, reel 26, 890g.77/3, "Future of Iraq Railways," American Consulate of Baghdad Thomas R. Owens to the Secretary of State, Washington, March 2, 1922; 1.

${ }^{19}$ Ibid.

20 NAUS, RG59, M1370, reel 26, 890g.77/7, "Interview with Yasin Pasha El-Hashimi, Minister of Public Works," American Consulate of Baghdad to the Secretary of State, Washington, January 19, 1923; 1.

${ }^{21}$ Colonial Office [Colonial No. 13], "Report by His Britannic Majesty's Government on the Administration of 'Iraq For the Period April, 1923--December, 1924," in Iraq Administration Reports, 1914-1932, vol. 7, 1920-1924, ed. Robert L. Jarman (Melksham and Oxford: Redwood Press Ltd. and Green Street Bindery, 1992), 685.

22 Sluglett, Britain in Iraq, 64.

${ }^{23}$ NAUS, RG59, M1370, reel 26, 890g.77/7, "Interview with Yasin Pasha El-Hashimi, Minister of Public Works," American Consulate of Baghdad to the Secretary of State, Washington, January 19, 1923; 2.

${ }^{24}$ Ibid.

25 NAUS, RG59, M1370, reel 26, 890g.77/2, "Transfer of the Mesopotamian Railways," Thomas R. Owens American Consulate of Baghdad to the Secretary of State Washington, February 16, 1922; 1.

${ }^{26}$ Colonial Office [Colonial No. 4], "Iraq. Report on Iraq Administration, April 1922-March 1923 [FO 371/8998]," in Iraq Administration Reports, 1914-1932, vol. 7, 1920-1924, ed. Robert L. Jarman (Melksham and Oxford: Redwood Press Ltd. and Green Street Bindery, 1992), 359.
} 
Iraq in 1922, a line constructed from Ali Gharbi and maintained as a private tramline for the company's use only. ${ }^{27}$

In 1923, the British government granted APOC control of an Iraqi railway line in Khanakin City, which gave APOC exclusivity for that particular line of $271 / 2$ miles in length. ${ }^{28}$ According to Sluglett in Britain in Iraq, the Iraqi government concluded that more liberal control over the Iraqi railways may lead to a more amicable relationship with Britain. The Iraqi governments "only hope for amelioration lay in tinkering with the details of the Anglo-Iraqi relationship, and trusting that Britain might eventually be persuaded."29 By August 31, 1929, the Iraqi government's desire to purchase the Iraq railways, along with the port of Basra, from the British had not occurred because the Iraqi government considered the asking price more than what the properties were worth. ${ }^{30}$ Further speculation in November 6, 1929 on the issue of Iraqi railways proved unfruitful since "the King's speech at the opening of Parliament did not touch on the [Iraqi] Government's program regarding the taking over of the Iraq Railways. Rumored that a mission was to be sent to London to negotiate but as yet no date of departure has been set." ${ }^{31}$ Nevertheless, the British wanted to maintain and extend railways while furthering its oil prospects. A purported railway project envisaged by the British was to parallel the route of the Mosul pipeline under both British and French discretion, and indirect U.S. control. $^{32}$

\section{The Kirkuk-Haifa Line to the Mediterranean: The Implications of Oil and the Mosul Question}

The Mosul pipeline and railway concession was a settled matter by 1928 between the Iraqi government and TPC consortium. However, the question of dominion over the Mosul region was a separate dispute, entwined with the concern for oil. The British placed elites into positions of authority within the Iraqi government that aligned themselves with British policymaking. Some historians have suggested that the British- Iraqi government relationship constituted a hybrid culture that enabled "the constant fusion and mutual synthesis between the cultures of the colonizer and the colonized and their representation as "self" and "other" become impossible to maintain." ${ }^{33}$ While the hybrid relationship between "colonizer" and "colonized" may apply to the Sunni elite and the British, and was a strategy the British tended to use in other parts of Iraq, the theory does not reflect how much of the population within Iraq lacked an amicable relationship with Britain and a voice in the main governmental body of Baghdad.

\footnotetext{
27 NAUS RG59, M1370, reel 26, 890g.77/13, "Future of Iraq Railways," Thomas R. Owens American Consulate of Baghdad to the Secretary of State, Washington, Copy letter form High Commissioner of Baghdad, March 2, $1922 ; 4$.

28 NAUS, RG59, M1370, reel 26, 890g.77/13, "Latest Information About Iraq Railways: Political, Commercial, and

Construction Plans," John Randolph American Consulate of Baghdad, December 26, 1923; 5.

${ }^{29}$ Sluglett, Britain in Iraq, 64.

30 NAUS, RG59, M1370, reel 26, 890g.77/30, "Document File Note, See: 790g.91/10, For: \#951," From Baghdad, Name: Randolph, August 31, 1929; 1.

${ }^{31}$ NAUS, RG59, M1370, reel 26, 890g.77/31, "Document File Note, See: 890g.032/8, For: \#1008," From Baghdad, Name: Brown, November 6, 1929; 1.

32 NAUS, RG59, M1370, reel 26, 890g.77/32, "Document File Note, See: 890g.6363 T 84/393, For: \#262," From Beirut, Name Brandt, December 3, 1929; 1.

${ }^{33}$ Bashkin, The Other Iraq, 3.
} 
Baghdad was the central authority of the Iraqi government, led by a Sunni Arab elite; yet, Basra, Baghdad, and Mosul consisted of a diverse population. On a religious level, according to Guiditta Fontana, there were a significant number of Christian and Jewish minorities present in an urban setting. ${ }^{34}$ Where as many of the Shi'a Arabs lived in the former vilayets Baghdad and Basra, along with a considerable number of Sunnis in Baghdad. ${ }^{35}$ While Shi'as constituted the majority of the Iraqi population like the other ethnicities, at the time they were not a single community. ${ }^{36}$ In Northern Iraq, there were ethnic groups such as Turkmen, Kurds, Arabs, with a smaller population of Chaldo-Assyrian Christians, and a larger Sunni population. ${ }^{37}$ However, Turkmen, Kurds, and Arabs were a blurred ethnic concept to those who presided in the area particularly because "an individual's or family's self-identity often stemmed from a combination of their preferred language and social status rather than their ancestry." 38 Therefore, the concept of nationalism was not prevalent during the 1920s amongst the ethno-heterogeneous population of Iraq. On the other hand, the British and the U.S. consulate were averse to nationalist sentiments, as they were concerned with maintaining control and stability over the region for resource exploitation. After all, "America's silent partnership with British power" hinged itself on the mandate system's "responsibility for bringing order to the underdeveloped territories taken over from the defeated states." 39

While factors such as the complex ethno-religious heterogeneity of the former Ottoman provinces of Basra, Mosul, and Baghdad, perhaps were considerations of the British policymakers in 1919-20, the British opted for "strategic rather than ethnic arguments" for defining the frontiers of Iraq. ${ }^{40}$ This was specifically evident in how the British conducted its agreements, or rather lack thereof, with the Kurds. A group of elite Kurds advocated for autonomy, sending a representative to the Paris Peace Conference in 1919 and leading to further discussions at the Conference of London and the San Remo Conference of 1920, this discussion was not a prevalent theme amongst the general Kurdish population. The San Remo Conference amounted to Article 62 in the Treaty of Sèvres, signed in August 1920 that called for "local autonomy for the predominantly Kurdish areas." ${ }^{41}$ Additionally, Article 64 detailed that such regions included those neighboring Mosul. However, the British found that promises based on creating ethno-homogenous states were inconvenient; after all, money and manpower to enforce such a policy was not lucrative, and to add to matters, the Higher Commissioner Sir Percy Cox advocated for the Kurdish fusion into the Iraqi state. ${ }^{42}$ The relationship between the policy of incorporation and the issue of Iraqi oil and railways may seem unclear. Before the Treaty of Versailles in 1919, the British and French petroleum ministers, Long and Bérenger, established a provisional covenant which amounted to "making over Deutsche Bank's former 25\% share in the TPC (confiscated during the war by the Custodian of Enemy Property) to French interests" in exchange for a former agreement of the

\footnotetext{
${ }^{34}$ Fontana, "Creating Nations, Establishing States: Ethno-Religious Heterogeneity and the British Creation of Iraq in 1919$23, " 2$.

35 Ibid.

36 Tripp, A History of Iraq, 3.

37 Bet-Shlimon, "Group Identities, Oil and the Local Political Domain in Kirkuk: A Historical Perspective," 914.

${ }^{38}$ Ibid.

39 Stivers, Supremacy and Oil, 119.

${ }^{40}$ Fontana, "Creating Nations, Establishing States: Ethno-Religious Heterogeneity and the British Creation of Iraq in 1919$23, " 2 / 3$.

${ }^{41}$ Holden, A Documentary History of Modern Iraq, 74.

42 Ibid.
} 
French to hand over Mosul to Britain back in 1918. ${ }^{43}$ Formalization of these arguments came to their crux during the San Remo Oil Agreement of 1920. After obtaining stock in TPC, the French was to have partial influence over the Kirkuk-Haifa line of 1928.

In the town of Kirkuk, there were those who identified as Kurdish that, along with other Kirkukis, who opposed Mosul's inclusion in Iraq. ${ }^{44}$ However, Kurdish nationalism was not a dominant sentiment during the 1920s. ${ }^{45}$ The issue of the "Mosul Question" came to the forefront during Iraqi centralization from 1918 to 1926. As "the seat of an Ottoman administrative subdivision within the province of Mosul," including Basra, it fell under Baghdad's authority during the Mandate period. ${ }^{46}$ Even after the British received the former Ottoman vilayet of Mosul from the French, where a large Kurdish population resided, Mosul was still a disputed territory because of Turkish claims to Mosul. However, as a result of "the exigencies of creating the Iraqi state outweigh[ing] special claims of Kurds," Britain took an additional step by to inviting them to endorse or "vote" in favor of a constitutional monarchy of King Faisal. ${ }^{47}$ In July 1921, Faisal's election was at a "suspiciously high 96 percent" approval rate from Iraqis. ${ }^{48}$ To further support this propaganda, according to one source, the Kurdish regions in Mosul and Erbil Divisions "twice declared their intention of uniting with the Iraq, once in June, 1921, before the arrival of the Amir Faisal, and again in August, [...] they swore allegiance to him as King." ${ }^{49}$ However, the Kirkuk Division asked for the postponing of the decision and had not sworn allegiance to the King. ${ }^{50}$

A political fault line emerged in Kirkuk between those "who wished to cooperate with AngloIraqi centralization and those who opposed it," while some elite families and tribes pandered to both political sides of the Mosul question. ${ }^{51}$ For instance, one elite patriarch "Abd al-Majid Beg obtained a relationship with the British authorities within Kirkuk and obtained a position as governor. ${ }^{52}$ Despite these symbiotic relationships on a local level between the British and the elites of Kirkuk, the British imperial agenda focused on the capital side of the Mosul question specifically with regards to oil concessions and railway expansion. American consulate of Baghdad John Randolph to the Secretary of State in Washington DC on July 10, 1924 reported that construction begun on the railway extension from Kingerban to Kirkuk. Consulate Randolph explained that the Kingerban-Kirkuk line was to be finished by November of that year, and noted that there was not an existing petroleum concession. Allegedly, the British negotiated the Kirkuk concession with the Turkish Petroleum Company (TPC). ${ }^{53}$ Meanwhile, the U.S. sought to influence the British positively by aligning with the imperial power, in hopes of gaining oil rights in Iraq. It was Standard Oil's partnership with TPC in 1925 that instituted U.S. involvement in matters of oil in Iraq.

\footnotetext{
43 Sluglett, Britain in Iraq, 70.

44 Bet-Shlimon, "Group Identities, Oil, and the Local Political Domain in Kirkuk: A Historical Perspective," 917.

45 Ibid.

${ }^{46}$ Ibid, 916.

47 Holden, A Documentary History of Modern Iraq, 74.

48 Ibid.

${ }^{49}$ Colonial Office, "Iraq. Report on Iraq Administration, April 1922-March 1923 [FO 371/8998]," 32.

50 Ibid.

${ }^{51}$ Bet-Shlimon, "Group Identities, Oil, and the Local Political Domain in Kirkuk: A Historical Perspective," 916/917.

52 Ibid, 917

53 NAUS, RG59, M1370, reel 26, 890g.77/17, "Negotiations for Irrigation, Agricultural and Petroleum Concessions In Iraq

(Mesopotamia)," American Consulate of Baghdad John Randolph to the Secretary of State, Washington, July 10, $1924 ; 1 / 2$.
} 
Since 1922, the Kirkuk-Haifa rail line was in a state of negotiation. It seemed like the line was going to be built by APOC under the discretion of AT Wilson. As Resident Manager of APOC, Wilson's association to the Haifa-Baghdad line, which was to connect to Kirkuk and Erbil, was as a contributor to the surveying force for the potential railway and pipeline. ${ }^{54}$ According to Wilson, Iraq needed improved communications "which are essential if its agricultural and mineral resources are to be developed." 55 TPC received the Kirkuk line concession instead of APOC in a 1925 agreement.

TPC was a consortium of oil companies originating prior to the First World War that had an existing agreement with the Ottoman Empire for Mesopotamian oil prospecting. However, as a result of the British being on the winning side at the end of the war, the German and Ottomans surrendered their shares of TPC to "Allied interests." ${ }^{56}$ By the late 1920s, the forfeited areas formerly owned by Germany and the Ottoman Empire were "owned jointly by the AngloPersian Oil Company (23.75 per cent), Royal Dutch Shell (23.75 per cent), Compagnie Français des Pétrole ( 23.75 per cent), a US-based consortium, later shared equally between Standard Oil of New Jersey and Mobil, and Gulbenkian (5 per cent)." ${ }^{57}$ TPC negotiated an oil concession agreement with the Iraqi government by March 1925. The TPC concession agreement also marked a turning point in American involvement in Iraq. In 1925, Standard Oil was able to participate in any projects TPC obtained. By 1928, the concession agreement between TPC and the Iraqi government allowed Standard Oil to benefit from its relationship with TPC. ${ }^{58}$ This meant a pipeline was to be built near the Kirkuk neighborhood, which led to an oil urbanized city. ${ }^{59}$

Evidently, the American Consulate to the Secretary of State explained that TPC was creating a pipeline from the oilfields in the Kirkuk area. ${ }^{60}$ The pipeline, estimating to be 700 miles long, was intended to reach the Mediterranean Sea at a Syrian port, and led "through a country where there are many wells which would mean probably an important saving on water transportation for the different pumping stations." 61 One consideration for the pipeline was for TPC engineers and geologists to create the line from the Kirkuk oilfields via the Hit-RutbaHauran-Haifa route near the Hejaz Railway for an estimated 800 miles long. ${ }^{62}$ According to Sluglett, by 1930 the compromise on the pipeline was to be above Rutba, with one part to Haifa and another to Tripoli, which was formally agreed upon with TPC as the Iraq Petroleum Company in March 1931. ${ }^{63}$

The relationship between Kirkuk and TPC was evident in terms of the 1925 agreement between the Iraqi government and TPC. TPC and the Iraqi government's agreement allowed

\footnotetext{
${ }^{54}$ NAUS RG59, M1370, reel 26, 890g.77/3, "Future of Iraq Railways," American Consulate of Baghdad Thomas R. Owens to the Secretary of State, Washington, March 2, 1922; 2.

55 NAUS RG59, M1370, reel 26, 890g.77/3, "Clipping from "the Bagdad Times" dated February 17, 1922," in "Future of Iraq Railways," American Consulate of Baghdad Thomas R. Owens to the Secretary of State, Washington, March 2, $1922 ; 3$.

${ }^{56}$ Tripp, A History of Iraq, 60.

57 Ibid.

58 Stivers, Supremacy and Oil, 130.

59 Bet-Shlimon, "Group Identities, Oil, and the Political Domain of Kirkuk: A Historical Perspective," 915.

${ }^{60}$ NAUS, RG59, reel 26, 890g.77/21, "Pipeline to Mediterranean: Route to be Studied: Haifa Route Preferred for Pipeline and Railroad," John Randolph American Consulate of Baghdad to the Secretary of State, Washington, January 17, $1928 ; 1$.

61 NAUS, RG59, reel 26, 890g.77/21, "Pipeline to Mediterranean: Route to be Studied: Haifa Route Preferred for Pipeline and Railroad," John Randolph American Consulate of Baghdad to the Secretary of State, Washington, January 17, 1928; 2

62 Ibid.

63 Sluglett, Britain in Iraq, 139.
} 
the company control of particular areas of Iraq. For instance, the terms of the previous concession agreement was for TPC to continue as a British-registered company and granted exclusive rights of exploration in all of Iraq, not including the former vilayet of Basra. ${ }^{64}$ It was under this agreement that put into motion the ratification of the tripartite Anglo-Turkish-Iraqi Treaty by Iraqi parliament, which settled the Mosul question in July 1926.65 TPC had a fixed period to select a number of land plots and to commit itself to begin drilling for oil within a few years. For each metric ton of oil that TPC produced, they were to pay an agreed sum to the Iraqi government. Meanwhile, the British relationship with TPC concerned itself with not only the pipeline but also a railway to connect the Mediterranean Sea and the Persian Gulf in order for the British Empire to have a developed line of communication as well as a way of guarding the mineral resources and railroad infrastructure "to be fought for in case of future wars." 66 This venture was in the works by the British since APOC planned to create a pipeline to the Mediterranean as early as 1922, suggesting that an undertaking and attentiveness toward the Kirkuk area preceded the TPC concession of 1928.

\section{Conclusion}

By 1931, IPC recognized Kirkuk as a beneficial center of industry and labor, which many Kirkukis relied upon for their livelihood. ${ }^{67}$ However, the concern for oil in Kirkuk preceded the

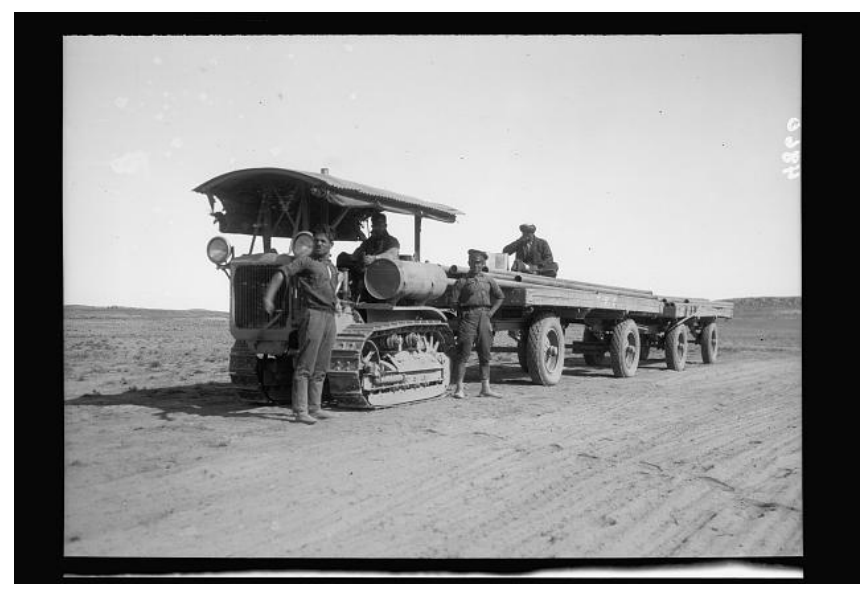
TPC concession of 1928. A decision to build a line from Kirkuk to the Mediterranean was in deliberation since 1922. U.S. involvement in the negotiations of the Kirkuk-Haifa line was a result of Standard Oil's (Socony) part ownership of TPC.

Figure 2: Oil wells and camp of the Iraq Petroleum Company. ${ }^{68}$

Despite Iraq gaining its independence from the British by 1932, the conditions of British authority remained. Many of the British officials

and advisers were present in Iraq and IPC's control over oil in Kirkuk was unabated. ${ }^{69}$ The U.S. preferred Iraq under longer guidance by the British. This was because the U.S. wanted to maintain their capitulations, while the British government instituted an initially de jure Iraqi independence to lessen any imposing financial burdens that it had on Britain. ${ }^{70}$ Meanwhile, the

\footnotetext{
${ }^{64}$ Tripp, A History of Iraq, 60.

65 Ibid.

${ }^{66}$ NAUS, RG59, reel 26, 890g.77/21, "Pipeline to Mediterranean: Route to be Studied: Haifa Route Preferred for Pipeline and Railroad," John Randolph American Consulate of Baghdad to the Secretary of State, Washington, January 17, $1928 ; 4$.

${ }^{67}$ Shlimon, "Group Identities, Oil, and the Local Political Domain in Kirkuk: A Historical Perspective," 920.

${ }^{68}$ American Colony (Jerusalem), Photo Department, photographer, "Iraq. Oil wells and camp of the Iraq Petroleum

Company. (5 miles S. of Kirkuk). Hauling of I.P.C. pipe line sections to lay across the desert to Haifa, port of outlet on eastern Mediterranean," Photograph (1932), Library of Congress, URL: http://www.loc.gov/pictures/resource/matpc.16256/, accessed: February 1, 2014.

${ }^{69}$ Tripp, A History of Iraq, 77.

${ }^{70}$ Stivers, Supremacy and Oil, 136/137.
} 
U.S. wanted Iraq to remain stable in order to protect its capital projects and its "open door" policy. After all, the U.S. Wilsonian principle of "self-determination" was in fact married to the idea of free and open markets. Therefore, preventing nationalistic sentiments amongst Iraqis was imperative to U.S. oil ambitions, as in their mind, this would have brought instability within the region. As long as the British authority preserved such stability, the U.S. enjoyed an open market and avoided the expense of maintaining dominion. ${ }^{71}$

\footnotetext{
${ }^{71}$ Ibid, 193.
} 


\section{Bibliography}

\section{Primary Sources}

American Colony (Jerusalem), Photo Department, photographer. "German Baghdad Railway, 190_. Building State at Mosul.” Photograph (between 1900 and 1910). Library of Congress. URL:

http://www.loc.gov/teachers/usingprimarysources/chicago.html\#photographs Accessed: February 1, 2014.

American Colony (Jerusalem), Photo Department, photographer. "Iraq. Oil wells and camp of the Iraq Petroleum Company. (5 miles S. of Kirkuk). Hauling of I.P.C. pipeline sections to lay across the desert to Haifa, port of outlet on eastern Mediterranean." Photograph (1932). Library of Congress, URL:

http://www.loc.gov/pictures/resource/matpc.16256/. Accessed: February 1, 2014.

Colonial Office [Colonial No. 4], "Iraq. Report on Iraq Administration, April 1922March 1923 [FO 371/8998]," in Iraq Administration Reports, 1914-1932, vol. 7, 1920-1924, ed. Robert L. Jarman, 187-318. Melksham and Oxford: Redwood Press Ltd. and Green Street Bindery, 1992.

Colonial Office [Colonial No. 13], "Report by His Britannic Majesty's Government on the Administration of "Iraq For the Period April, 1923--December, 1924," in Iraq Administration Reports, 1914-1932, vol. 7, 1920-1924, ed. Robert L. Jarman, 319-512. Melksham and Oxford: Redwood Press Ltd. and Green Street Bindery, 1992.

Foreign Office. "Report by His Majesty's High Commissioner on the Finances, Administration and Condition of the 'Iraq for the period from $1^{\text {st }}$ October 1920 and $31^{\text {st }}$ March 1922 [FO 371/8998]." In Iraq Administration Reports, 1914-1932, vol. 7, 1920-1924, edited by Robert L. Jarman, 3-100. Melksham and Oxford: Redwood Press Ltd. and Green Street Bindery, 1992.

National Archives of the United States (NAUS), RG59: Records of the Department of State relating to the Internal Affairs of Asia (M5144) 1910-1929, reel 26.

\section{Secondary Sources}

Bashkin, Orit. The Other Iraq: Pluralism and Culture in Hashemite Iraq. Stanford: Stanford University Press, 2009. 
Bet-Shlimon, Arbella. "Group Identities, Oil, and the Political Domain of Kirkuk: A Historical Perspective." In Journal of Urban History, vol. 38: 2012, 914-932. Accessed: February 10, 2014. http://dx.doi.org/10.1177/0096144212449143.

Bernhardsson, Magnus T. Reclaiming a Plundered Past: Archaeology and Nation Building in Modern Iraq. Austin: University of Texas Press, 2005.

Dodge, Toby. Inventing Iraq: The Failure of Nation Building and a History Denied. New York: Columbia University Press, 2003.

Earle, Edward Mead. Turkey, the Great Powers, and the Bagdad Railway: A Study in Imperialism. New York: Macmillan, 1923.

Fontana, Guiditta. "Creating Nations, Establishing States: Ethno-Religious Heterogeneity and the British Creation of Iraq in 1919-23." In Middle Eastern Studies, 46:1, 1-16, (Feb 12, 2010). Accessed February 10, 2014. http://dx.doi.org/10.1080/00263200902760535.

Holden, Stacy E. A Documentary History of Modern Iraq. Edited by Stacy E. Holden. Gainesville: University Press of Florida, 2012

McMeekin, Sean. The Berlin-Baghdad Express: the Ottoman Empire and Germany's Bid for World Power. Cambridge: Belknap Press of Harvard University Press, 2010.

Sluglett, Peter. Britain in Iraq: Contriving King and Country. New York: Columbia University Press, 2007.

Stivers, William. Supremacy and Oil: Iraq, Turkey, and the Anglo-American World Order, 1918-1930. Ithaca and London: Cornell University Press, 1982.

Tripp, Charles. A History of Iraq. Cambridge: Cambridge University Press, 2000. 
Portland State University McNair Research Journal 2015

\title{
Come Out Come Out Wherever You Are: A Content Analysis of Homeless Transgender Youth in Social Service Literature
}

\author{
by \\ Shannon Crossley
}

Faculty Mentor

Dr. Ben Anderson-Nathe

Citation: Crossley, Shannon. Come out come out wherever you are: A content analysis of homeless transgender youth in social service literature. Portland State University McNair Scholars Online Journal, Vol. 9, 2015. 


\begin{abstract}
Homeless, transgender youth are underrepresented in research studies in the United States and over-represented among the lesbian, gay, bisexual, transgender and queer (LGBTQ) transitionalage $(16-24)$ homeless youth population, at a reported $20-40 \%$ of the entire homeless youth population. Although this figure is staggering, it is not representative of the actual number of LGBTQ youth currently living on the streets. Exact numbers are unknown due to fear of victimization and discrimination faced both by their homeless peers and in services that are established for homeless youth. This study critically examined how homeless, transgender, transitional-age youth are represented in or ignored by the social service scholarly literature. The study implemented a thematic analysis of academic articles from 2008 - 2013 with a specific focus on homeless, transitional-age youth found in the Social Services Abstract database. Themes identified from the selected articles relate to perceptions of services, barriers to care, gender identity, risk factors, and a comparison of heterosexual to homosexual homeless youth. These factors will be used to determine the level of representation or exclusion from available studies about homeless transgender youth.
\end{abstract}

Keywords: transgender, homeless, youth, transitional-age, services, community support 


\section{Introduction}

Although the homeless youth population in the United States is near impossible to precisely calculate, a 2010 report by the Center for American Progress indicates that $1.6-2.8$ million youth in the United States on any given night are homeless. Lesbian, gay, bisexual, and transgender youth comprise $20-40 \%$ of homeless young people, compared to only $5-10 \%$ of the general youth population. While youth homelessness has been the subject of multiple academic articles, research focusing on homeless self-identified transgender youth has been extremely limited in both scope and quantity. An individualized study of homeless self-identified transgender youth is necessary to have a better understanding of how they are accommodated throughout homeless youth services, especially in how policy and cultural competency training effect shelter dynamics.

When it comes to research on homeless self-identified transgender youth, most scholars readily agree that the population is over-represented in the homeless youth community yet highly underrepresented in current research. This argument usually ends, however, with studies that primarily focus on homeless youth as a whole. Some studies include all members of both the homeless youth population and homeless gender non-conforming population into broad research, while others, albeit very few, have focused on homeless transgender specific research. This is troubling, given that homeless transgender youth have specific needs that differ from other members of the homeless youth community and are not addressed in the majority of services available to homeless youth on a national level. Necessary studies focusing specifically on addressing the issues that homeless transgender youth face when accessing services and the likelihood of this vulnerable population having positive experiences in spaces that are expected to be safe and secure are limited. Drawing attention to the need for individualized homeless transgender youth, this study pays special attention to what is lacking in academic literature with a specific focus on this homeless population. Persons who identify as gender non-conforming are often stigmatized and excluded from the dominant group and are more often than not "barred from equal access to resources, rights, and protection because of their devalued social identity and status" (Button, O'Connell \& Gealt, 2012, p. 25). The realities of institutionalized oppression are evident in the marginalization, discrimination, and victimization of homeless transgender youth, even in the service systems that have been established to offer support and security.

Given their increased risk of poverty and homelessness, transgender youth are in need of adequate and intentionally respectful homeless services. Youth focused homeless services are designed to be a social safety net for those who need a secure place to access and attain support in getting back on their feet. Currently, transgender youth are left to struggle against substantial barriers without that needed safety net (Mottet \& Ohle, 2006, p. 83-84). This study critically analyzed the content of existing research and for how homeless transgender youth are either included or excluded in the context of academic literature. The content analysis draws attention to and specifically addresses how homeless transgender youth are included or excluded from current academic literature.

The study draws on intersectionality theory (Hesse-Biber, 2012, p. 13) to emphasize the links between class, gender, and sexuality and how the system of patriarchy perpetuates marginalization within this population. Although homeless research for transgender youth is gradually increasing, what is missing in academic literature is "an overview of practice models for organizations that provide services, safe spaces, and advocacy for transgender youth" (Shepard, 2013, p. 98). This study evaluated existing academic literature, discussing this gap in academic literature and postulates the necessity of further research and planning for transgender specific services. The study answered the following research question: among academic journals published in the United States between 2008 and 2013 with focus on youth homelessness, how are transgender youth included or excluded? If homeless transgender youth are included in the articles included in this 
sample, what is the language and context being used? If they are excluded from articles in the sample, what homeless population is being discussed and in what context? How does exclusion affect homeless transgender youth populations?

\section{Review of the Literature}

The current social service system, as well as academic research, has failed homeless LGBTQ transitional-age youth, specifically transgender homeless youth. This failure is reiterated in the academic literature on the subject of homeless youth populations. As much as $43 \%$ of homeless LGBTQ transitional-age youth have been forced out of their homes, either familial and/or foster, because of family prejudice toward their sexual orientation or gender identity, lack of understanding, and plain and simple homophobic ideologies (Durso \& Gates, 2012, p. 9).

Transgender youth often share scenarios of being told to leave the minute they shared their gender identity with family. The Ali Forney Center in New York City reported that 77\% of their LGBTQ clients had experienced physical or emotional abuse, including assault, sexual assault, and even attempted murder at the hands of their families (Quintana, Rosenthal \& Krehely, 2010, p. 9). Collectively, homeless transgender youth face violence, homophobia, and transphobia in accessing social services that is often similar to the situations that caused them to leave home in the first place. As many as 20 to $40 \%$ of homeless youth identify as LGBT[Q] (lesbian, gay, bisexual, and transgender [queer]) (Ray, 2010, pg. 180-181). These numbers are slightly speculative due to the inability to accurately count and report in a transient and research wary population. Homeless transgender youth are part of a community that is already marginalized, and essentially invisible by societal expectations of gender identity and expression.

According to Nancy Taylor (1994), lack of definition, stigma, and visibility of homeless LGBTQ youth partially explain why public policy change efforts have failed. Taylor also stresses that before a community will change social policy for a specific population, they need to first recognize that the population exists. As paramount as the need for validating the concept of visibility for transgender youth, one obstacle in defining this homeless population has been the lack of ability in quantifying the number of LGBT youth. Many LGBT youth, homeless transgender young people in particular, hide their sexual identities due to the social stigma associated with being a sexual minority (Kidd, 2007; Taylor 1994). By directly addressing the above mentioned issues of this vulnerable population in academic literature, academics can provide authenticating awareness to this problematic societal and political issue in the United States.

Western society has constructed gender as being either male or female. This socially constructed gender binary aids in the facilitation of an anti-homosexual and anti-transgender ideology toward those who deviate from traditional gender norms, perpetuating homophobia and transphobia. While gender includes male and female an individual's expression exists on a spectrum that is vast and complex. Wilchins (2004) states, "Challenging oppressive gender structures and making gender rights a priority are critical steps toward universal freedom from punishment for gender nonconformity" (p. 27). Within the homeless LGBTQ youth population transgender youth experience a higher incidence of violence and victimization in large part due to their gender expression. The implications for homeless transgender youth in deconstructing this binary are that the implementation of national policy would allow for their program and shelter needs to be established across the board in agencies.

Dean Spade (2008) states that "the majority of homeless shelter systems in the United States have no written policies regarding the placement of trans [gender] residents and therefore enforce this myth [that transgender people do not exist] in their daily operations by placing people according to birth-assigned gender" (p. 36). Current national and state-by-state policy, as limited as it is, is a blanket policy for all homeless youth and is limited in its scope and verbiage. The 
majority of shelter systems have strict policies in place regarding sex segregation. The problems youth face are stated in the literature by Thaler, Bermudez, and Sommer (2009):

Too often, transgender youth are misunderstood and mistreated, even harassed, assaulted, or raped by the staff and other residents at temporary homeless shelters and youth transitional living programs. When these facilities refuse to accept transgender youth, or fail to treat them in accordance with their gender identity, these youth are put in an untenable situation: they must either stifle their authentic gender identity in order to access services and treatment, to the detriment of their overall well-being, or they must live on the streets. (157)

As problematic as this information is, a handful of organizations nationally have implemented policy conducive to homeless youths' gender identity and expression as opposed to the socially constructed gender binary, related to overall treatment, especially in regards to sex segregation. It is pivotal for all youth homeless shelters to take the necessary precautions to protect transgender youth by enforcing trans-inclusive nondiscrimination policies on a national level and rigorously enforced by funders of these agencies. I would highly suggest the implementation of mandatory sensitivity training for all staff and a zero-tolerance policy; this policy would be expected from not only staff but also all clients utilizing these services. The implementation of this policy would be the first step in offering a safe space for transgender youth.

Institutional policy in social service organizations is pervasively heterosexist and transphobic; this is evident in that a number of homeless shelter programs have no written policies regarding bed assignments of transgender youth. Consequently they are placed according to their assigned sex at birth rather than their gender identification/expression. Dean Spade states (2008), "For many transgender people, this means that seeking shelter means becoming a target for harassment and assault in a large facility; this results in chronic homelessness for many who are afraid to face such conditions" (p. 36). Acknowledgement of transgender clients by social service agencies is questionable, which further perpetuates the societal marginalization and discrimination of these youth. In this context, homeless transgender youth not only have their voices muted but their agency and self-determination has been diminished through pervasive systematic heterosexism and patriarchal ideology. "Discrimination and lack of LGBT[Q]-affirmative services often makes homelessness more dangerous for sexual and gender minorities than for the general [homeless] population" (Yu, 2010, p. 341). Many youth who identify as transgender and are forced to comply with shelter policy regarding sex segregation will choose to be on the streets rather than conform to heteronormative expressions of gender identity. This situation leaves youth at a higher risk of facing street victimization and harassment.

Unfortunately, federal funding is insufficient in reaching the majority of LGBTQ homeless youth. Lack of state, local, and federal government funding is said to be the primary barrier to improvement in services related specifically to the reduction of LGBTQ related services (Durso \& Gates, 2012, p. 4). The majority of LGBTQ homeless youth may never receive access to support services or housing opportunities, and most community-based providers serving this population allude to a lack of bed capacity as their primary concern. "Less than a dozen local nonprofit organizations nation-wide offer focused services to LGBTQ homeless youth, and most are either on the west or east coasts" (LBGTQ Youth, n.d.). Limited resources are, in effect, another explanation for the inability of most facilities to offer LGBTQ specific services that address identifiable needs. Benjamin Shepard (2013) states, "with federal and state funds for services, shelters, and housing for homeless youth lacking, trans [gender] youth are forced to rely on their own networks for survival" (p. 101). Without secure and inclusive access to social service facilities and organizations, homeless transgender youth are compelled to survive on the street; such survival can at times contribute to young people engaging in a range of high-risk behaviors in order to meet basic survival needs (Cray, Miller, \& Durso, 2013, p. 15-16). 
The needs of homeless transgender youth far surpass the availability of non-restrictive, inclusive, and secure environments to seek services and shelter. What these organizations need is explicit cultural sensitivity and non-discriminatory training for staff and volunteers who operate necessary services in order to comply with specific needs of this homeless population. "Clear written policies covering issues such as respect, confidentiality, housing placement, showering and bathroom arrangements, and harassment should be developed and all staff should know and understand them"(Mottet \& Ohle, 2006, p.99). The increase in staff training can be established with funding increases specified for staff cultural sensitivity training in service agencies. An in-house policy of respect in regards to a youth's self-identified gender identity and expression cannot be understated in order for transgender youth to gain a sense of self-efficacy and transition off the streets. "In order to better protect LGBT[Q] youth in these housing programs from violence, social service agencies must adopt regulations aimed at curbing all violence in homeless youth programs as well as regulations addressing the particular problems faced by LGBT[Q] youth" (Hunter, 2008, p. 543). I find it essential to reiterate the importance of a secure and inclusive environment to the success of homeless transgender youth to end their individual cycle of homelessness. Ernst Hunter (2008) emphasized this importance:

Because LGBT[Q] youth are particularly vulnerable to abuse in homeless youth facilities and they constitute such a large percentage of the youth that agencies regulating these facilities are charged with protecting, these agencies must enact regulations specifically addressing the problems faced by homeless LGBT[Q] youth. These regulations should include nondiscrimination policies, mandated LGBT[Q] sensitivity training, and policies promoting the formation of homeless youth housing programs specifically for LGBT[Q] youth. Such regulations are an important step toward remedying the widely unaddressed problems faced by homeless LGBT[Q] youth (p. 552-553).

When transgender youth find themselves on the streets, sadly it is a typical result of ostracization from either their familial home and/or human services organizations (i.e. group homes, foster care, etc.) (Hunter, 2008, p. 545-546). These barriers to care complicate potential efforts made by homeless transgender youth aiming for self-determination. This exclusion can create apprehension about accessing services and many youth find that staying on the street may just be better for them.

As transgender youth find themselves on the streets, they tend to have experiences different from their homeless peers. Transgender youth who are accessing basic services, shelter and housing facilities, experience additional factors which include "particularly high rates of mental health and substance use problems, suicidal acts, violent victimization, and a range of HIV risk behaviors" (Keuroghlain, Shtasel, \& Bassuk, 2014, p. 66). Homeless transgender youth are both forced and somtimes willing to do what many may consider outrageous just to survive. A 2013 report by the Center for American Progress stated that "engaging in sex as a means of survival increases exposure to potential trauma for these youth, and increases their vulnerability to violence, rape, and exposure to disease" (p. 15). Rather than seeking out available services, some youth on the street resort to dangerous sexual acts because service agencies that have been established to prevent the very experiences are not meeting that need. Given the intense needs of LGBT youth experiencing homelessness, it is imperative to understand their unique experiences and develop responsive practices and policies (Keuroghlain, et al., 2014). Homeless transgender and LGB youth have very similar needs when accessing services. However, transgender youth face segregation issues in the housing aspect of services and experiences of discrimination and victimization both on the streets and within available services. This disparity is especially important to acknowledge and has been reiterated in the aspect of the academic literature search in the Social Service Abstract database that was used in this content analysis study. Inadequate social services bring about a lack of knowledge about around issues that surround transgender homelessness within social services and the general population. This perpetuates existing stigmatization and oppression of an 
already marginalized group. Marginalization frequently leads to internalized oppression, which further affects whether or not transgender youth will seek out and find support within the available services (Spicer, 2010). By emphasizing the lack of academic literature available in a database that targets future social service workers this study will support the specific needs of transgender young people in agencies that offer homeless services.

\section{Methods:}

This study investigated research on how homeless, transgender youth are included or excluded in current academic literature and what that looks like in regards to this population. Many studies have been conducted on the experiences of homeless youth in accessing services; however, homeless transgender youth are all but invisible in academic literature in the United States.

\section{Data Collection and Analysis}

Empirical studies and reviews related to homeless youth in the United States during the years 2008 - 2013 were identified using academic literature indexed in the Social Service Abstract database using the keywords homeless AND (youth OR transitional-age) AND (services OR community support). The search resulted in 146 non-duplicated articles, 15 of which were randomly selected for analysis. These keywords reflect overarching themes associated with homeless youth, with the goal of identifying whether gay, lesbian, bisexual, and/or specifically transgender youth studies are included in the resulting search in the general social service literature. The following content categories were examined in the initial reading of the random sampled academic literature: methods, data collection, settings, point of service, demographics, risk factors, protective behaviors, barriers to service, correlates to homelessness, policy, and sources. In using the basic premise of a conventional content analysis, the aim of this study was to describe a phenomenon with limited research literature on a specific subject (Hsieh, 2005, p. 1279). Developing categories were initially used to decide the content importance of each academic article and create definitions of each primary category. Next, subcategories were developed in order to identify more specific content of each article and allow for the prevalence to facilitate a more focused analysis of how transgender youth are represented or excluded from each article.

In the second reading of the randomly sampled literature, more specific analysis focused on the initial content themes and subcategories were then created for analysis. They are as follows: settings depict the geographical location of the study and the type of social service represented in the study. Point of service depicts the service program (i.e. basic services, mental health, etc.). Demographics are representative of the youth in the study. Risk factors depict youths' experiences coinciding with homelessness (i.e. substance use, victimization, etc.). Protective behaviors depict how youths manage aspects of self-preservation in correlation to homelessness. Barriers to service are the contributing factors that prevent homeless youth from accessing social services (i.e. discrimination, mental illness, etc.). Correlates to homelessness are the physical and psychological dynamics that have made homelessness the only option youth feel they are left with (i.e. kicked out, runaway, etc.). Policy represents federal, state, local, and agency policy established for homeless youth. Sources depict who is being used to back up the researchers' argument (i.e. government, academic, etc.).

Given that my literature search for this study resulted in a small sample, I can only assume that the academic literature search conducted for this study may have been too limited in its search criteria. Therefore, I chose to do the same search in the Social Service Abstract database using the same search words, omitting the date restrictions. This revised search resulted in only 399 academic studies. I also did a search using the original keywords, using the specific date range of 2008 - 2013 in the Social Service Abstract database; the only difference with this search was adding transgender into the keywords. This search resulted in three articles. Removing the date 
restriction resulted in four articles. I find these searches problematic considering the amount of sources I located for my literature review using Google Scholar with the same search terms "homeless AND (youth OR transitional-age) AND (services OR community support) AND (transgender)", also using the specific date range from 2008 - 2013 which resulted in 5,600 articles and 20,200 when transgender was removed from the list.

\section{Findings}

In my initial analysis, I anticipated a minimum of five articles that included transgender youth, specifically information tailored to the needs of homeless transgender youth when accessing services. However, homeless transgender youth are effectively absent from my random sample of academic literature. Of the 15 randomly sampled articles, 13 did not mention this population at all. Two of the articles focused on LGB youth but with no mention of transgender youth; Rosario, Schrimshaw, and Hunter (2012) discussed a developmental milestone approach in direct correlation to homelessness among lesbian, gay, and bisexual youth and subsequent risk factors. This study was a comparison of homeless and non-homeless LGB youth focusing on risk factors that are related to this population becoming homeless. Participants included 156 self-identified lesbian, gay, and bisexual youth ages 14 - 21. Grafsky, Letcher, Slesnick, and Serovich (2011) also studied risk factors for gay, lesbian, and bisexual youth. Risk factors included increased substance use and mental health symptoms with the correlation between treatment for "street-living youth GLB and non-GLB identified youth" (p. 572). Participants ranged between $14-22$ years and totaled 268; 52 identified as GLB and 205 identified as heterosexual.

Three articles mentioned transgender youth, but only in the content of the study's methods and/or measures. One study (Tyler, et al., 2012) "examines frequency and correlates of service utilization" (p. 1344) by homeless youth that examined the traits that are connected with service utilization. Of the 249 participants ages $14-21$, 137 were female identified, 112 were male identified, and 44 identified as LGBT. The second article that scarcely mentioned transgender youth is by Tyler (2008). This study compared homeless heterosexual male and female participants and homeless GLB participants in the context of the correlation with early events of sexual abuse and neglect, depressive symptoms, risky sexual behavior, and survival sex with sexual victimization. Another aspect of this study examined the extent of sexual orientation and sexual victimization. Participants included 69 females and 103 males ages $19-26 ; 31$ self-identified as GLB. Kennedy, et al. (2012) studied the different types of influence pertaining to social networks, romantic partner, and individual as predictors of unprotected sex for homeless youth. Participants in this study were 20 female and 20 male, ranging from $13-23$ years. Of the remaining ten articles transgender and LGB youth were not mentioned in any way. The intentional exclusion of LGBT youth from academic literature reiterates the point of default heterosexism when creating studies on homelessness. The systematic pervasiveness of transgender invisibility in a dominant heterosexual society perpetuates both heterosexism and stigma, not only in academic literature but also in social service agencies.

Of the 15 random samples of academic literature, two articles explicitly discuss homeless transgender youth. Shepard (2013) examines three case studies to answer the question "how have LGBTQ activists paved the way for both trans direct action and direct services?" (p. 110). Shepard first focused their attention on the work of transgender activist Sylvia Rivera and how her work influenced trans* inclusive social action and the establishment of services catering to the needs of LGBT, in particular, the transgender community in different aspects including transgender specific services for homeless youth in New York City. Rivera's passion and activism was instrumental in the creation of a number of homeless transgender youth specific services and organizations. This included Sylvia's Place Shelter, which segued into New Alternatives, which provided basic services for LGBT youth, also in New York City. New Alternatives has created a secure environment for homeless transgender youth by "mirroring the population we're [they are] serving" ( $p .103$ ) by 
having staff that, for the most part, have been homeless at one point in their lives and also some of the staff are transgender. Creating this inclusive space for transgender youth allows for them to have a sense of community, for most this is the first time they have experienced this.

Kate Barnhart, director and founder of New Alternatives, runs the organization using a harm reduction model. The premise in using this model is to build a partnership with transgender youth rather than using social control tactics by meeting youth where they are at as opposed to where societal expectations expect them to be. By utilizing a harm reduction model, services designed to aid this vulnerable population the emphasis is on staff/client trust building client autonomy and self-determination. Considering that trust is the "central ingredient to this model of care" (Shepard, 2013, p. 104) for youth providers who utilize a harm reduction model patience and understanding are a key component in the practice of trust building. In moving past a more traditional approach in homeless youth services that emphasizes paternalism by stressing "collaboration and partnership rather than social control" (Shepard, 2013, p. 104), New Alternatives delivers a respect for client autonomy and support engagement throughout their organization. Shepard has focused their study on services that work with and for homeless transgender youth by creating mutual respect, equality, and support for self-determination and autonomy. Serving youth through a harm reduction model has proven fruitful in a small number of organizations that implement this practice; however focused research on this model is limited.

Gattis (2009) addressed psychosocial problems associated with sexual minorities in the United States by reviewing empirical literature using ecological systems theory to address risk factors, barriers to care, and correlates to homelessness. In this context, sexual minorities are defined by UC Berkeley Gender Equity Resource Center as "members of sexual orientations or who engage in sexual activities that are not part of the mainstream and to members of sex groups that do not fall into the majority categories of male or female" (Definition of Terms, n.d.). Gattis (2009) conducted a review of studies comparing homeless sexual minorities and homeless non-sexual minorities. It is an important factor in understanding the specific needs of homeless transgender youth to do these comparison studies considering the risk factors for transgender youth drastically differ from homeless heterosexual youth.

The needs of transgender youth also differ in comparison to the needs of gay, lesbian, and bisexual youth. Studies for these specific needs are few and far between, as Gattis (2009) points out. Most of the studies in Gattis' review were inclusive of homeless and non-homeless gay, lesbian, and bisexual youth and rarely, if at all, included transgender youth in their studies; both epidemiological and correlational studies were reviewed. Gattis' study specifically associates transgender youth in relation to risk factors as opposed to previously mentioned studies that explicitly exclude transgender youth from the discussion in the random sample of academic research included in my study. Methodological strengths and weaknesses of homeless sexual minority youths' academic literature were reviewed and critiqued by Gattis as well. A substantial limitation with research design of this at-risk population is noted in the fact that "studies are not designed to understand the underlying causes or casual pathways to homelessness" (Gattis, 2009, p. 1080).

One key issue in academic literature is in the context of measurement, with specific focus on definitions as a research guide. Specific and consistently used definitions of homelessness, sexual orientation, and associated terms is lacking as a standardized measurement in academic literature. Gattis expresses this concern: "most of the studies relied [rely] on self-identification, which allows for social reliability bias and systemic bias to become of increasing concern" (Gattis, 2009, p. 1083). Both Shepard (2013, p. 102) and Gattis (2009, p. 1090) support my argument by reiterating the exclusion in academic literature and the gap in services for homeless transgender youth. By excluding transgender youth from conversations around homelessness the cycle of oppression is being perpetuated within social service literature. 
In response to the exclusion of homeless transgender youth in the above 13 articles in my sample, this exclusion may be suggestive of the lack of visibility in both the transgender population and homeless population. The aforementioned idea of invisibility is both political and societal in how many people view these two specific populations. Researchers are afforded the privilege of an academic platform to share knowledge of important social issues that plague this country. Unfortunately the search for such articles was futile at best and limited within the Social Service Abstract database. As I see it, in analyzing these articles, most of them could have easily included transgender youth in their studies. For example, Rosario, et al. (2012) and Grafsky. et al. (2011) both discuss risk factors of homeless lesbian, gay, and bisexual (LGB) youth and how interventions need to be modified when compared to heterosexual youth. Homeless transgender youth would easily fit into these studies for they share similar experiences as homeless LGB youth. I feel that the authors of these two studies have reiterated my point that homeless transgender youth are invisible not only in U.S. society but also in academic research.

\section{Discussion}

The current study examined academic literature on homeless self-identified transgender youth. This study explored the weaknesses of previous studies in how transgender youth are discussed in the literature. I used literature located in the Social Service database because it is designed for those who are either furthering their education to work in social services or are already working in social services. By doing a random search, I saw exactly where homeless youth studies are falling short, in particular for the transgender youth population. Given their increased risk of poverty and homelessness, transgender youth are in need of access to secure and respectful homeless services. Youth focused homeless services are designed to be a social safety net for those who need a secure place to access and attain support in getting back on their feet. Currently, transgender youth are left to struggle against substantial barriers without that needed safety net (Mottet \& Ohle, 2006, p. 83-84). This study is necessary to draw attention to, and identifying, the specific needs and barriers of the homeless transgender youth community.

A key, and disappointing, discovery is that the majority of my samples focused on heterosexual or gender identity non-specific homeless youth, with only two articles discussing homeless LGBT youth. One of the two articles discusses the specific needs of transgender youth in accessing services and the lack of secure resources. Lacking access to research on the needs of this at-risk population I question the level of education being offered to students who are in social service fields now or in the future; what are they learning and how are they learning it? By focusing studies in academic literature that analyze causation of homelessness for transgender youth services and programs would support homeless youth organizations and social service workers in utilizing this information in the formation and implementation of transgender specific services. Consequently, accessibility has a greater potential to be more transgender inclusive and would likely result in a higher rate of successes in addressing the needs of this population.

While I understand the importance and need for specific research that focuses on homeless LGBTQ population as a whole, in order to better understand transgender youth and their particular needs when accessing homeless youth services, providers need access to more academic literature. Considering that accurate statistics concerning homeless transgender youth are unavailable, due largely in part to this population being studied under the LGBT umbrella as opposed to individual studies. A significant limitation in this area of research is that most of the current studies are not designed to understand the underlying pathways to homelessness. Transgender youth are at greater risk of being assaulted and experiencing harassment than homeless heterosexual youth, in creating studies specifically focused on this aspect studies would be far less limited in their numbers. A limited number of studies focus specifically on homelessness within the transgender youth population, it is my deepest belief that when the number of studies increase the number of adequately trained social service agencies and staff will grow. By deconstructing Western 
heteronormative gender binary government and homeless youth agencies can/will have a more empathetic perspective of gender expression within agencies that serve the homeless LGBTQ youth community. This in turn will help to ensure a secure and inclusive environment in which these youth will be given the tools to end the perpetual cycle of homelessness.

I am adamant about the importance, and necessity, of systemic change within the foundations of social service organizations and explaining why the emphasis needs to happen for transgender youth. Meezan and Martin (2003) state, "The need for social work research on the transgender population is both significant and immediate, given the lack of appropriate services available to them" (p. 13). A specific focus for social service academics and organizations need to have an understanding of the effects that marginalization and discrimination have on the youth who utilize services. For the most part organizations are ill prepared to address the needs of transgender youth, which differ significantly to heterosexual youths' needs; serving the needs of homeless youth is not a one size fits all solution. Without adequate, and accurate, literature on these issues and experiences of individualized groups accessing secure service and shelters the perpetuation of youth homelessness is likely to be over-representative of the youth population in the United States as a whole. Giving special attention to the positive outcomes of a harm reduction model with homeless transgender youth those who work in the social service arena have the potential to acquire the skills to have a more positive and successful rate of transitioning homeless transgender youth off the streets and into mainstream society. This model and its' successes have all but excluded from academic literature as well.

I have noticed throughout this process that using specific academic databases to identify homeless transgender youth in research studies is limited at best and lacks inclusion of this vulnerable population. Identifying the specific needs of at-risk and vulnerable homeless populations is an important part of being able to apply a specific needs assessment when transgender youth access agencies. The consequences of excluding this population can be paramount for those youth who want/need to access services and have a well informed and empathic staff available to them. Without explicit knowledge and understanding of how this vulnerable population experiences victimization and discrimination because of their gender identity/expression the services they seek have the potential to perpetuate the negative experiences they are already experiencing on a daily basis. This in turn has great potential in leaving this population feeling like they have no sense of belonging and lack acceptance in program services and refuse to return. A lack of belonging may subsequently lead to transgender youth being isolated from their homeless peers and any prospective means of a support system, forcing them into the street economy in order to survive. It is of the utmost importance for social service providers to be informed with current concerns of this population, which will in turn allow for ongoing insight into the needs of transgender youth. Social Service students and providers will then be better equipped to address and meet the specific needs of transgender youth by offering access to unbiased and supportive information utilized through academic literature. This progression will be less likely to happen as long as this population remains excluded from the majority of academic literature. 


\section{References}

Bannon, W. M., Beharie, N., Olshtain-Mann, O., McKay, M. M., Goldstein, L., Cavaleri, M. A., Lolacono, M. L., Elwyn, L. J., Kalogerogiannis, K., Torres, E., Paulino, A., \& Lawerence, R. (2012) Youth substance use in a context of family homelessness. Children and Youth Services Review, 34, 1, 1-7. doi:

http://dx.doi.org/10.1016/j.childyouth.2010.12.002

Button, D. M., O'Connell, D. J., \& Gealt, R. (2012). Sexual minority youth victimization and social support: the intersection of sexuality, gender, race, and victimization. Journal of Homosexuality, 59, 1, 18-43. doi: 10.1080/00918369.2011.614903

Definition of Terms. (n.d.). Gender Equity Resource Center. Retrieved August 1, 2014, from http://geneq.berkeley.edu/Igbt_resources_definiton_of_terms\#top

Durso, L. E., Gates, G. J., Palette Fund., True Colors Fund., \& Williams Institute (University of California, Los Angeles. School of Law). (2012). Serving our youth: Findings from a national survey of services providers working with lesbian, gay, bisexual and transgender youth who are homeless or at risk of becoming homeless. New York, NY: Palette Fund.

Farrar, L., Schwartz, S. L., \& Austin, M. J. (2011). Larkin street youth services: Helping kids get off the street for good (1982-2007). Journal of Evidence-Based Social Work, 8(1-2), 106123. doi: http://dx.doi.org/10.1080/15433714.2011.541826

Gay and Transgender Youth Homelessness by the Numbers. (2010, June 12). Center for American Progress. Retrieved June 1, 2014, from http://www.americanprogress.org/issues/lgbt/news/2010/06/21/7980/gay-andtransgender-youth-homelessness-by-the-numbers/.

Gattis, M. N. (2009). Psychosocial problems associated with homelessness in sexual minority youths. Journal of Human Behavior in the Social Environment, 19, 8, 1066-1094. http://dx.doi.org/10.1080/10911350902990478

Glassman, M., Karno, D., \& Erdem, G. (2010). The problems and barriers of RHYA as social policy. Children and Youth Services Review, 32, 6, 798-806. doi: http://dx.doi.org/10.1016/j.childyouth.2010.01.017

Grafsky, E. L., Letcher, A., Slesnick, N., \& Serovich, J. M. (2011). Comparison of treatment response among GLB and non-GLB street-living youth. Children and Youth Services Review, 33, 5, 569-574. doi: http://dx.doi.org/10.1016/j.childyouth.2010.10.007

Heinze, H. J., \& Hernandez, J.-S. D. M. (2009). Intervention for homeless and at-risk youth: Assessing youth and staff perspectives on service provision, satisfaction and quality. Vulnerable Children and Youth Studies, 4, 3, 210-225. doi: http://dx.doi.org/10.1080/17450120902890578

Heinze, H. J., Jozefowicz, D. M. H., \& Toro, P. A. (2010). Taking the youth perspective: Assessment of program characteristics that promote positive development in homeless and at-risk youth. Children and Youth Services Review, 32, 10, 1365-1372. doi: http://dx.doi.org/10.1016/j.childyouth.2010.06.004

Hesse-Biber, S. N. (2012). Feminist research: Exploring, interrogating, and transforming the 
interconnections of epistemology, methodology, and method. The Handbook of Feminist Research: Theory and Praxis, (pp. 2-26).

Hsieh, H. \& Shannon, S. (2005). Three approaches to qualitative content analysis. Qualitative Health Research, 15, 1277-1288.

Hunter, E. (2008). What's good for the gays is good for the gander: Making homeless youth housing safer for lesbian, gay, bisexual, and transgender youth. Family Court Review, 46, 3, 543-557. doi: 10.1111/j.1744-1617.2008.00220.x

Kennedy, D. P., Tucker, J. S., Green, H. D., Golinelli, D., \& Ewing, B. (2012). Unprotected sex of homeless youth: Results from a multilevel dyadic analysis of individual, social network, and relationship. AIDS and Behavior, 16, 7, 2015-2032. http://dx.doi.org/10.1007/s10461-012-0195-0

Keuroghlian, A. S., Shtasel, D., \& Bassuk, E. L. (2014). Out on the street: A public health and policy agenda for lesbian, gay, bisexual, and transgender youth who are homeless. American Journal of Orthopsychiatry, 84(1), 66-72. doi: http://dx.doi.org/10.1037/h0098852

Kidd, S. A. (2007). Youth homelessness and social stigma. Journal of Youth and Adolescence, 36(3), 291-299. doi: http://dx.doi.org/10.1007/s10964-006-9100-3

LGBTQ Youth. (n.d.). National Alliance to End Homelessness. Retrieved April 10, 2014, from http://www.endhomelessness.org/pages/lgbtq-youth

Meezan, W., \& Martin, J. I. (2003). Research methods with gay, lesbian, bisexual, and transgender populations. Gay and Lesbian Social Services, 15, 1, 1-14.

Mottet, L., \& Ohle, J. (2006). Transitioning our shelters making homeless shelters safe for transgender people. Journal of Poverty, 10, 2, 77-101. doi: 10.1300/J134v10n02_05

Quintana, N. S., Rosenthal, J., \& Krehely, J. (2010). On the streets: The federal response to gay and transgender homeless youth. Center for American Progress. . Retrieved from website: http://www.americanprogress.org/issues/2010/06/pdf/Igbtyouthhomelessness.pdf

Ray, N. (2010). Lesbian, gay, bisexual and transgender youth: An epidemic of homelessness. In S. Lowrey \& J. Burke (Eds.), Kicked Out (pp. 180-200). Ypsilanti, MI: Homofactus Press L.L.C.

Reconnecting Homeless Youth Act of 2008, H.R. 5524. (2008). Retrieved on July 5, 2014 from THOMAS (Library of Congress).

Rosario, M., Schrimshaw, E. W., \& Hunter, J. (2012). Risk factors for homelessness among lesbian, gay, and bisexual youths: A developmental milestone approach. Children and Youth Services Review, 34, 1, 186-193. doi: http://dx.doi.org/10.1016/j.childyouth.2011.09.016

Sanders, B., Lankenau, S. E., Jackson-Bloom, J., \& Hathazi, D. (2008). Multiple drug use and polydrug use amongst homeless traveling youth. Journal of Ethnicity in Substance Abuse, 7, 1, 23-40. doi: http://dx.doi.org/10.1080/15332640802081893

Shepard, B. (2013). From community organization to direct services: The Street Trans Action 
Revolutionaries to Sylvia Rivera Law Project. Journal of Social Service Research, 39, 1, 95-

114. doi: http://dx.doi.org/10.1080/01488376.2012.727669

Spade, D. (October 2008). Trans formation. Los Angeles Lawyer, 34-41.

Retrieved from http://www.lacba.org/Files/LAL/Vol31No7/2525.pdf

Taylor, N. (1994). Gay and lesbian youth: Challenging the policy of denial. Journal of Gay \& Lesbian Social Services, 1, 3-4, 39-73. doi: 10.1300/J041v01n03_02

Thaler, C., Bermudez, F., \& Sommer, S. (2009). Legal advocacy on behalf of transgender and gender nonconforming youth. In G. Mallon (Ed.), Social Work Practice with Transgender and Gender Variant Youth (2nd ed., pp. 139-160). New York, NY: Routledge.

Thompson, S. J., Bender, K., Windsor, L., Cook, M. S., \& Williams, T. (2010). Homeless youth: Characteristics, contributing factors, and service options. Journal of Human Behavior in the Social Environment, 20, 2, 193-217. doi:

http://dx.doi.org/10.1080/10911350903269831

Tyler, K. A. (2008). A comparison of risk factors for sexual victimization among gay, lesbian, bisexual, and heterosexual homeless young adults. Violence and Victims, 23, 5, 586-602. doi: http://dx.doi.org/10.1891/0886-6708.23.5.586

Tyler, K. A., Akinyemi, S. L., \& Kort-Butler, L. (2012). Correlates of service utilization among homeless youth. Children and Youth Services Review, 34, 7, 13441350. doi: http://dx.doi.org/10.1016/j.childyouth.2012.03.010

Tyler, K. A., \& Melander, L. A. (2012). Poor parenting and antisocial behavior among homeless young adults: Links to dating violence perpetration and victimization. Journal of Interpersonal Violence, 27, 7, 1357-1373.

doi:http://dx.doi.org/10.1177/0886260511425244

Wilchins, R. A. (2004). Queer Theory, Gender Theory: An Instant Primer. Los Angeles, California: Alyson Publications.

Yu, V. M. D. (2010). Shelter and transitional housing for transgender youth. Journal of Gay \& Lesbian Mental Health, 14, 4, 340-345. doi:

$10.1080 / 19359705.2010 .504476$ 
Portland State University McNair Research Journal 2015

The Media's Presentation of The Second Chance Act: Funding for Reentry Following Prison

by

Ailene Joyce Farkac

\section{Faculty Mentor: \\ Dr. Lee Shaker}

Citation: Farkac, Ailene J. The Media's Presentation of The Second Chance Act: Funding for Reentry Following Prison. Portland State University McNair Scholars Online Journal, Vol. 9, 2015. 


\begin{abstract}
The US prison system has multiplied by four since 1980; each year about 730,000 people enter state and federal prisons and 700,000 people exit. As a result of this expansion, there is a massive increase of formerly incarcerated people reentering local communities every year. Budget cuts in prison programs and in local government's social services are causing these individuals to be less educated and less prepared for reintegration; communities are also ill prepared to absorb them. The Second Chance Act was signed into law by President Bush on April 9, 2008. It authorized a pool of about $\$ 393 m$ (renewed in 2009 and 2013) to government agencies and nonprofit community organizations to provide services to the formerly incarcerated following their release from prison or jail. How the media presents reentry and the Second Chance Act and how that depiction affects public perception of the issue requires further examination. Newspaper articles in the LexisNexis Academic database are the basis for this content analysis of print news media coverage of the Second Chance Act. Media framing is important to examine as public attitudes are influenced by newspaper articles, and those attitudes influence government policy.
\end{abstract}




\section{Introduction}

Over the last 30 years, a steep increase in the number of people sentenced to prison in the United States has led to a corresponding steep increase in the ex-offender population (Cole 2001, Gest, 2001). Mass incarceration through the 1980's and 1990's created a reentry crisis evident in the first years of the millennium and continues in this decade. There are over 2.2 million people in prison and jail nationally today, but there never was a coherent national plan for mass incarceration in America (Martin 2013). Consequently, the reintegration of former prisoners is one of the most profound challenges facing American society (Petersilia 2003). President Bush announced, in his 2004 State of the Union address:

"This year, some 600, 000 inmates will be released from prison back into society. We know from long experience that if they can't find work, or a home, or help, they are much more likely to commit crime and return to prison. . . . America is the land of second chance, and when the gates of the prison open, the path ahead should lead to a better life."

Following Bush's call to action, the Second Chance Act (SCA) of 2008 was written as the government's response to the reentry crisis. It authorized nearly $\$ 340$ million (in its first two years and has since been renewed with proposed funding through 2019) in grants and other means available to state and local government agencies. The nature of the complicated and multi-layered Act is to encourage states to provide employment assistance, substance abuse treatment, housing, family programming, mentoring, victims support, and other services which can help reduce re-offending and violations of probation and parole. It emphasizes that strategies and initiatives must be developed in collaboration with community groups, faith-based organizations, service providers, citizens, victims and formerly incarcerated individuals (Wilkinson 2005).

The importance of American citizens' support for legislative acts such as the SCA must be understood because citizens' political preferences directly influence government and public policy (Gilens 1996). News media coverage of the SCA and reentry will directly affect the attitudes of US citizens towards ex-inmates as they return home. Prior research has not explored what news coverage of the SCA looks like. This content analysis will explore the newspapers' presentation of the SCA. The level of coverage, in terms of number of newspaper articles that mention the SCA, as well as how reentry is framed will be analyzed and used to determine how media framing contributes to US citizens' support of funding for reentry following prison. The SCA is an important piece of legislation; it is critical to explore how media frames it and reentry so support for individuals exiting the prison system can be improved. Newspapers only barely acknowledged the SCA as newsworthy when it was introduced, and in the last six years, even as it was renewed, coverage in newspapers was increasingly less.

\section{Background of the Second Chance Act}

The numbers of incarcerated people who will return to their communities is expected to grow (Petersilia 2005). Experts and the BJS state that at least $95 \%$ of all state prisoners will be released from prison at some point (Cooper, Durose and Snyer, 2014). Each year approximately 730,000 people enter state and federal prisons and 700,000 people exit. Another seven million are released from shorter terms in jail. A recent BJS study tracked 400,000 state prisoners from 30 states released in 2005. Within three years of release 68 percent (two-thirds) were re-arrested; within five years of release 76 percent were arrested after committing a new crime (Cooper, Durose and Snyder 2014). With recidivism rates rising and communities concerned with public safety, the government's response via the SCA is an important piece of legislation.

The Second Chance Act of 2007, titled HR1593, Community Safety through Recidivism Prevention is a reauthorization of a grant program for reentry of ex-offender 
into the community and supplants the Omnibus Crime Control and Safe Streets Act of 1968 (CSJ 2007). The Bureau of Justice Assistance (BJA) states that the purpose of the SCA is to reduce recidivism, increase public safety, and assist states and communities to address the growing population of inmates returning to communities.

The SCA is divided into two main sections: Title I: Amendments related to the Omnibus Crime Control and Safe Streets Act of 1968, and Title II: Enhanced Drug Treatment and Mentoring Grant Programs; there are multiple subsections as well as a "for other purposes" section.

Title I elements include improvements to existing programs and the creation of new programs to improve reentry services. Subtitle A reauthorizes Adult and Juvenile Offender State and Local Reentry Demonstration Projects. These programs, run by a state, a unit of local government, territory, Indian tribe or some combination will focus on four areas: jobs, housing, substance abuse/mental health treatment and families. In much of the government's literature the SCA is referred to as taking a holistic approach; the reality is the SCA has many components, and this section can be broken down in terms of grants with specific goals:

- Federal demonstration grants to government agencies and nonprofit organizations for safe and successful reintegration of ex-offenders into the community

- To provide employment services, substance abuse treatment, housing, family programming, mentoring, victim services, and methods to improve release and relocation

- To provide mentoring services to adult and juvenile offenders

- To implement family-based treatment programs for incarcerated parents who have minor children

- To provide guidance to the Bureau of Prisons for enhanced reentry planning procedures

- To provide information on health, employment, personal finance, release requirements and community resources

Subtitle B creates several new programs, each with its own funding allocation:

- State, tribal, and local reentry courts, to monitor and provide services for juvenile and adult ex-inmates

- Prosecution drug treatment alternative to prison programs - these may be newly developed and implemented or expanded current programs

- Family based substance abuse treatment-these are designed as alternative to prison programs that include coordination between correctional facilities and government agencies and are programs in residential treatment facilities

- Evaluation and improvement of education at prisons, jails and juvenile facilities

- Technology careers training

Title II of the SCA focuses on Enhanced Drug Treatment and Mentoring Grant Programs, divided into three subtitles with separate funding amounts:

A. Drug treatment: creates the Offender Reentry Substance Abuse and Criminal Justice Collaboration Program by offering competitive grants to improve drug treatment inside correctional facilities

B. Mentoring grants to non-profit organizations: funds may be used to mentor adults and juveniles during incarceration and through transition back to the community

C. Administration of justice reforms: this component instructs the Attorney General and the Director of the Bureau of Prisons (BOP) to establish a federal prisoner reentry strategy

This section also creates a pilot program for elderly and family reunification for nonviolent offenders and provides assistance for obtaining identification.

The SCA divides reentry research into four sections:

1. Juvenile and adult offender reentry

2. Parole or post-incarceration supervision violations and revocations 
3. Addressing the needs of children of incarcerated parents

4. Depot naltrexone for heroin addiction treatment

Funding for reentry research is approximately $\$ 10$ million for each fiscal year of renewal.

The "for other purposes" in the verbiage of the Act includes the establishment of the National Offender Reentry Resource Center (NRRC). Administered by the BJA, of the US Department of Justice (DOJ), the SCA provides education, training and technical assistance to the various agencies who work within reentry. The NRRC is operated by and is a project of the Council of State Governments (CSG) Justice Center. According to the BJA, the NRRC has key project partners with the Urban Institute and other committees of non-profit and service organizations in the reentry field. The primary goal of the Center is to provide information to the service providers and community organizations who deliver services under SCA programming.

Initially introduced in 2005, the SCA was returned to the House of Representatives for amendments before it was finally approved by President Bush on April $9^{\text {th }}, 2008$. The SCA has been deemed the first comprehensive legislation that attempts to address the multifaceted problems ex-inmates face following incarceration (Gideon 2010). The bill was supported by more than 200 organizations and has broad bipartisan support, with 113 cosponsors in the House and 34 in the Senate. It was approved to provide $\$ 191$ million for ex-prisoner rehabilitation, reentry and reintegration programs, including $\$ 65$ million in grants to state and local governments for reentry initiatives, $\$ 15$ million to non-profit organizations for mentor programs and transitional services, $\$ 1$ million for state research grants, $\$ 10$ million for reentry task forces and drug treatment provisions, $\$ 5$ million for career training, \$20 million for education at prisons and jails and \$20 million for prisonbased and family treatment programs(Re-Entry Policy Council, 2007). The SCA was renewed in 2009 and again in 2013 (see Table 1). As of July, 2014, the BJA has awarded more than $\$ 250$ million, through about 300 grants to government agencies and nonprofit organizations. In President Obama's Fiscal Year 2015 budget, he allocated $\$ 115$ million for the SCA; it has not yet been approved by Congress.

SCA grant programs are funded and administered by the Office of Justice Programs in the DOJ. Within the Office of Justice Programs, the Bureau of Justice Assistance awards SCA grants serving adults, and the Office of Juvenile Justice and Delinquency Prevention awards grants serving youth returning from the juvenile correction facilities.

A central goal of the SCA is to encourage collaboration of the criminal justice, public health and social service systems to promote successful reentry by facilitating access to resources and opportunities among partnering agencies. Grant recipients are required to develop a reentry strategic plan not only containing measurable performance outcomes, but must have a 50 percent reduction in recidivism rates over five years (HR 1593). The (BJS) references a national study of state inmates which found that over the course of their lifetimes, each of the individuals studied had accrued an average of about nineteen charges; 95 percent of them will eventually return home and over two thirds of them will have been rearrested within three years (Bureau of Justice Statistics, 2002). The goal of the SCA is to look at reentry by way of new and improved, funded, collaborative strategies. For that to happen, communities, families, faith-based and non-profit organizations must work together to help individuals transition from prison, back to their communities as law abiding, tax paying citizens.

Table 1. Second Chance Act Funding

\begin{tabular}{|l|l|l|l|l|l|}
\hline FY09 & FY10 & FY11 & FY12 & FY13 & FY14 \\
\hline$\$ 25 m$ & $\$ 100 m$ & $\$ 83 m$ & $\$ 63 m$ & $\$ 67.45 m$ & $\$ 55 m$ \\
\hline
\end{tabular}




\section{Literature Review \\ Part 1 Context}

According to the BOJ statistics, in 1980 , there were fewer than half a million people in US jails and prisons; today there are over two million. Violent crime rates have not increased; in fact it is eighteen percent less today with more than 60 percent of all inmates incarcerated for non-violent offences (Wimsatt 1999). An increased use of prisons in response to crime, combined with radical changes in sentencing laws led to this era of mass incarceration, which is at the core of the fourfold increase of prisoners in the US prison system.

Sentencing policies in this country have changed dramatically over the past generation. New gang laws, drug laws, three-strike laws, mandatory minimum sentences, and Truth in Sentencing laws which took away judges' discretion in sentencing, combined with drastic changes to parole and community supervision have caused more people to go to prison for longer sentences and had an especially devastating effect in minority communities. Incarcerating more people requires building new prisons; the cost of construction has forced governments to cut budgets for schools, after-school programs, drug treatment, job training and many social programs that also especially affect poor and minority communities. Inside the newly built prisons, policymakers in many states cut funding for programs and services such as education and skills trainings. Ex-inmates released today are less prepared, offered less assistance in their reintegration and face an increasing likelihood of being returned to prison (Petersilia 2003).

Since President Bush's call to action, the issue of reentry has received increased attention from government officials, community organizations and academics. In January, 2011, US Attorney General Eric Holder established the Reentry Council, a federal interagency group with lofty, generalized goals; its creation was also a component of the SCA, satisfying the requirement of collaboration among criminal justice, public health and social service agencies.

The dominant narrative of contemporary American penal culture holds that the US stands unmatched in the western world in its harsh treatment of lawbreakers (Green 2013). Criminal justice policy has been guided by the "tough on crime" era of the last 30 years. The penal harm theory (Clear 1997) was born out of this ideology; it states that inmates should endure additional pain and suffering and not just have their rights taken in order to make the punishment deliberately harder. Upon leaving prison, the individual, in theory, has paid their debt to society, yet the punishment continues through the reentry process and beyond.

In his review of the SCA, editor of Federal Sentencing Reporter, Michael O'Hear applauds the "reentry movement" and points out the past attempts of legalism's hold on penal law and policy. Strict adherence to the law (legalism) has consisted of astonishing harshness in sentencing (mass incarceration) and a tendency to view offenders as undifferentiated, willful lawbreakers not as individual human beings with unique needs and limitations (O'Hear 2007). Increased attention towards reentry helped SCA legislation come to fruition. The way the media frames the SCA and how the public perceives the issue as a consequence requires further examination.

\section{Part 2 Theory}

This content analysis of media presentation follows Martin Gilens' (1999) study of the relationship between public misperceptions of race and poverty and the American news media. Gilens' analyzed three weekly news magazines over forty-five years and looked specifically at the racial content in their coverage of poverty. Gilens claims that media coverage shapes public perceptions, which in turn affects public policy. He argues that the images used in the portrayal of poverty in the national news do not accurately reflect the reality of poverty in America and those news media distortions in turn drive public misperceptions about race and poverty. 
The logic of Gilens' work rests on the concept of media framing (Iyengar, 1991). Iyengar posits that most Americans possess little information about current issues and events but, simultaneously, they possess policy preference on a wide range of political issues. The way a news story is framed will profoundly influence "decision outcomes." At a general level, framing refers to subtle alterations in the statement or presentation of judgment and choice problems. As a result of those alterations, a change in decision outcomes is called the "framing effect." Significant framing effects have been demonstrated in experimental studies (Iyengar, 1991.) In media presentation of reentry, and specifically in relation to Gilens content analysis, newspapers' framing of reentry may affect citizens' and communities' willingness to support SCA programs. This support, or lack of is epitomized in areas such as employment and housing and in overall acceptance, which is reflected by an ex-inmate's ability to actually find employment or rent an apartment as a felon.

Joan Petersilia, winner of the Stockholm Prize in Criminology asserts that reentry is one of the most profound challenges facing American society (Petersilia 2003). Petersilia has spent over thirty years studying crime and public policy; her research on parole reform, prisoner reintegration and sentencing policy has fueled changes in policies throughout the nation. It is important for US citizens to care about reentry policy, according to Petersilia, because of challenges which are different today than they were twenty or thirty years ago. In a co-authored article with Urban Institute Senior Fellow, Jeremy Travis in Crime and Delinquency (2001), they argue that from a number of policy perspectives, the age-old issue of prisoner reintegration has taken on a critical importance with the most profound changes placing a new demand on parole and community-based supervision. They attribute these changes to three primary areas; the growth in imprisonment rates, the fragmentation of sentencing philosophies and the weakening of parole. These three developments, over the last twenty years are at the root of a system that is no longer effective. "More people are going to prison under differing sentencing philosophies and returning home through a system of reintegrating that has diminished capacity to perform that function and now serves more to return reentry failures to prison's front door"(Petersilia \& Travis 2001).

One challenge for policymakers is that the public will not support community-based programs until they have been shown to "work," and they will not have an opportunity to work without sufficient funding and research (Petersilia, 2000). Media framing of parole and reentry become increasingly important when public policy and new research relies on community support;

Experts in the field of criminal justice agree that reducing crime requires a collaborative effort and must include a focus on improving the lives of ex-inmates post- prison. American criminal justice policy has been dominated by a legalist mind-set (consistent severe penal response to deter crime and reinforce law-based moral norms (O'Hear 2007). The legalist approach to criminal justice is contrasted with a harm-reduction approach which deliberately avoids moral condemnation and recognizes that criminal acts may sometimes represent a failing of society as much as a failing of the criminal. This content analysis searches news articles to determine how reentry is framed in the media.

\section{Part 3 Empirical Evidence}

In his poverty in the media study, Gilens found that over $50 \%$ of the images of people shown in articles about poverty are African American. In reality, the average percentage of African Americans among the poor during this period was $29.3 \%$ (Gilens 1999.) He argues that news media distortions coincide with public misperceptions about race and poverty and that both are biased in ways which reflect negatively on the poor in general and on poor African Americans in particular (Gilens 1996). Gilens concluded that the public dramatically misunderstands the racial composition of America's poor, which has consequences harmful to both the poor and to the Black communities. Media presentation of the SCA affects public opinion and attitudes in a different but related context. Services to 
the American poor and those reintegrating into communities following incarceration nationwide require support from US citizens. Public policy is driven by public opinion and those opinions are influenced by media presentation of the issue.

Across the country and increasingly throughout the Western world (Wacquant 1999), punitive criminal-justice policies have a grossly disproportionate impact on racial minorities (Bobo 2006). When the relationship between racial disparities in incarceration and citizen's acceptance of punitive policies was studied, the outcomes mimicked Gilens' results (Hetey 2014). In this study, when the penal institution was represented as "more Black," people were more concerned about crime and expressed a greater acceptance of punitive policies than when the penal institution was represented as "less Black" (Hetey 2014).

Levels of support for the SCA can be determined by a number of different ways. Public opinion surveys are one useful yet fallible method; there have been worthwhile surveys which looked at support for transitioning ex-offenders. A 2006 study examined attitudes of US voters toward prisoner rehabilitation and reentry policies (Krisberg and Marchionna 2006). Of those polled, by strong majorities, US voters understand the difficulties faced by ex-inmates in terms of basic needs and they also agree that receiving communities suffer from a lack of preparedness to receive people post incarceration. Only $7 \%$ of those polled were not in favor of planning for reentry. This survey was conducted two years prior to the SCA legislation; four in five respondents supported the proposed SCA, with support closely divided between strongly (41\%) and somewhat (38\%). In comparison, one in seven (14\%) oppose the bill, while $8 \%$ are not sure. When asked about the pending SCA, $78 \%$ were in strong support; of those almost half expressed strong support.

Another public opinion study that same year looked at public attitudes toward rehabilitation, punitiveness and support for the Second Chance Act (Loveland 2006). This New York State and Tri-State Region poll found about $83 \%$ of the public is supportive of the SCA and thus support of ex-offenders' rehabilitation and reintegration. Loveland concluded that knowledge of public attitudes toward prisoners' rehabilitation and reintegration, and reentry programs can help policymakers approach the problem effectively.

How the media presents reentry by way of the SCA can affect levels of support for reentry strategies and public policies. This content analysis of newspapers' framing of the SCA complements prior studies of public support of reentry, and also relates to recent sociological theories of punishment, penality ${ }^{1}$ and a shift in penal philosophy. How newspapers frame the issue will affect the level of support for ex-inmates in their communities, which will directly affect recidivism rates and public safety.

\section{Study aim and hypothesis}

This study seeks to examine the media's presentation of the Second Chance Act and its accompanying narrative of reentry with the goal of understanding how information about reentry is presented by newspapers to the American public. Using a content analysis of newspaper articles, a level of supportive, neutral or negative presentation will be observed. The main research question which guides this content analysis is:

\section{$R Q 1$ "How do newspapers in the US, report information about the Second Chance Act of 2008?}

Hypotheses that test more specific questions are:

\footnotetext{
1 "Penality" as used by Michael Hallett in Reentry to What? Theorizing Prisoner Reentry in the Jobless Future, draws from the work of Foucault, David Garland's classic statement on the meaning of "penality" refers to the complex of laws, processes, discourses, and institutions which are involved in this sphere and is a synonym for legal punishment in this broad sense" (1990 p.10, fn12). He goes on to say that "Penality communicates meaning not just about crime and punishment but also about power, authority, legitimacy, normality, morality, personhood, social relations, and a host of other tangible matters" (1990, p252). See Punishment and Modern Society
} 


\section{H1: There will be more coverage of The Second Chance Act during funding renewal years $(2008,2009$, and 2013$)$ than in non-renewal years. H2: Local newspapers will contain more coverage of The Second Chance Act than national newspapers. \\ H3: There will be more quotes from the federal government than any other source. \\ H4: There will be more mention of saving money than mention of reducing crime or improving lives.}

\section{Methods}

Newspapers were chosen because they are widely read, are both local and national in coverage and distribution and they have been published continuously for many decades. Using the LexisNexis Academic database, newspapers in the United States between the years 2007-2014 were searched for articles that contained the terms "Second Chance Act" and "prison." The search yielded 195 articles; of those 143 were included. Articles were eliminated for the following reasons: they were published by non-US newspapers, they were about The Second Chances Act (a marriage legislative act), they were press releases or legal press releases or contained only incidental mention of the term "second chance act." Examples of national papers include The New York Times and the Washington Post; examples of local papers include the Oregonian and the Daily News; alternative papers such as the Portland Mercury were not indexed by LexisNexis and therefore were not included. A code book was created to identify the components of each article to be analyzed (See Appendix A).

Articles were coded by year of publication and word count, type of newspaper (local or national) and article type (hard news, opinion, editorial or letter to the editor.) The type of article was listed in LexisNexis and was recorded along with the word count and year of publication. The sources or the people quoted in each article were classified by the following types: government (federal or local government), expert/academic, community organizations, ex-offender or program participant, faith-based, Department of Corrections or other. A count variable represents how many times the same source is quoted. If there were multiple sources, each was noted and if there were multiple citations from any source, the number of quotes was recorded.

The coding category of "positive individual outcomes" tracks the description of potential program services such as skill development, services to ex-inmates, drug treatment, job training or employment finding services, housing, education, mentoring or parenting classes or programs. If more than one of these services is mentioned in the same article, then the number of mentions is recorded. Other positive individual outcomes are recorded as a text variable, listed by name and included in the total.

The variable "positive structural outcome" represents information present in an article that describes outcomes for society as a whole. These outcomes include mentions of saving money, reducing crime, reducing recidivism and/or improving lives. If the article has specific mention of the term "improving lives," it was coded as such; the mention of a program designed to improve the lives of ex-inmates by including treatment for addiction or job training is also included in improving lives. Other positive structural outcomes are recorded as a text variable and listed by name.

The amount of SCA grant award is recorded as a dollar figure. The number of people served by a program created using a grant from the SCA is recorded as a number. Mention of success of a program is recorded as either present or not present. When a program is specifically named as created and funded by an SCA grant, the name is recorded as a text variable. If a program created is specifically for women or youth, the mention is recorded. If there is more than one agency mentioned in any article, including government and social service agencies, or any combination of organizations it is coded as "multiple agencies." 
When there is mention of an ex-inmate or an ex-inmate's family for any reason, it is coded as a number representing how many times the ex-inmate or ex-inmate's family is mentioned. If a candidate is mentioned in an article, the number of mentions of the candidate is recorded.

Mention of race or racial disparity is recorded including a text variable; if race is mentioned it is coded as present in the article; the specific race is recorded as a text variable and if racial disparity or inequity based on race is noted, the races mentioned are recorded as a text variable.

\section{Findings}

Table 1 displays descriptive characteristics of the sample population of newspaper articles. Of the 143 total included articles, $63 \%$ are hard news $(\mathrm{N}=90)$, and $28 \%$ are opinion/editorial $(\mathrm{N}=40)$. Only $4 \%$ are letters to the editor $(\mathrm{N}=6)$ and $4 \%$ are other $(N=6)$.

Table 1 Descriptives

\begin{tabular}{|l|r|r|}
\hline & \multicolumn{2}{|r|}{$\mathrm{N}$} \\
\hline $\begin{array}{l}\text { Average word } \\
\text { count }\end{array}$ & \multicolumn{2}{|r|}{661} \\
\hline Local newspaper & $30 \%$ & 41 \\
\hline National newspaper & $70 \%$ & 101 \\
\hline Type of article & & $\mathrm{N}$ \\
\hline News & $63 \%$ & 90 \\
\hline Op/Ed & $28 \%$ & 40 \\
\hline Letter & $4 \%$ & 6 \\
\hline Other & $4 \%$ & 6 \\
\hline
\end{tabular}

Figure 1 contains the breakdown of article type by year. There was more conversation during 2007, the year it was introduced $(N=27)$ than during the most recent renewal year of 2013 when there were only four news articles and zero op/ed or letters. In 2008, the year the SCA was signed into law, the largest number of related newspaper articles was published $(\mathrm{N}=47)$. During the he next two years since its introduction, the SCA received the most attention from reporters in terms of opinion and editorial pieces; since those years, very few opinions have earned a spot in the newspaper.

H1states there will be more news reporting during SCA funding renewal years (2008, 2009, 2013) with limited data during non-renewal years. In 2007, there were 26 articles, in 2008 , the first year of funding there were 46 articles. The next year, 2009, the SCA was renewed and there were 20 articles; the following year, 2010, coverage was reduced by half and there were 11 total articles in newspapers. In 2011, coverage increased though funding was not renewed with 20 articles that year. 2012 saw 10 articles and 2013, a funding renewal year there were a total of 4 articles in national and local newspapers combined. 
Figure 1 Articles by year and type

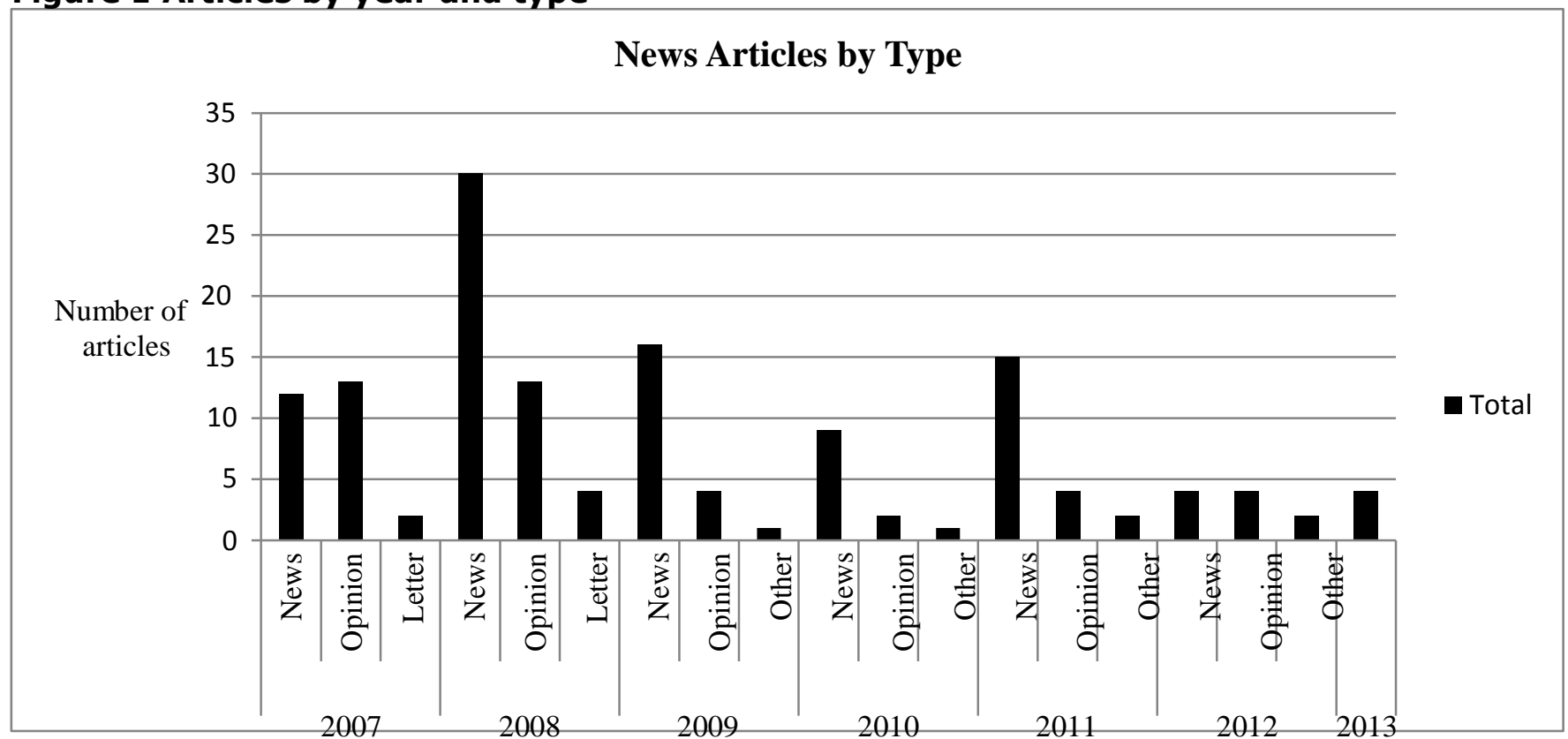

The sources of information about the SCA for the included articles are illustrated in Table 3. Local and federal government officials are responsible for the majority of the news with local government as a source in $56 \%(\mathrm{~N}=79)$ of the total articles and federal government sources at $32 \%(\mathrm{~N}=45)$. Community organizations operating programs using SCA funds and participants from such programs are sources in about one third of the articles. Other sources include community members and employers.

H2 stated local newspapers will contain more coverage of the SCA than national newspapers; local newspapers have significantly more $(p<.05)$ articles than national papers about the SCA. Also notable is that local government sources are the primary sources in local papers. In both local and national newspapers, there are statistically more $(p<.05)$ government representatives as sources than any other source.

Table 3 Sources

\begin{tabular}{|l|r|r|}
\hline & $\begin{array}{l}\text { Of } \\
\text { total } \\
\text { articles }\end{array}$ & \multicolumn{1}{|c|}{$\mathrm{N}$} \\
\hline Federal Government & $32 \%$ & 45 \\
\hline Local Government & $56 \%$ & 79 \\
\hline Experts/Academics & $32 \%$ & 45 \\
\hline Community Organizations & $27 \%$ & 39 \\
\hline Program participant & $23 \%$ & 32 \\
\hline Faith based Organization & $10 \%$ & 14 \\
\hline Department of Corrections & $18 \%$ & 26 \\
\hline Other & $24 \%$ & 34 \\
\hline
\end{tabular}

$H 3$ suggests that federal government sources provide most of the information about the SCA and its related programs. When federal and local sources were compared, there were significantly more federal government sources $(p<05)$ in national newspapers with federal government as a source in more than half of the articles. In local papers however, 
local government provided significantly more information $(p<.05)$ with almost $70 \%$ of the articles in local papers reporting information from local government and $23 \%$ (in local papers) coming from federal sources.

One other thing to note is that expert and academic sources are cited in $32 \%(N=46)$ of the total articles. Section 3 of HR 1593 authorizes $\$ 10,000,000$ for 2009 and 2010 (each) for research in many areas of pre and post reentry. These studies are not cited in the included articles but the funding has produced a network of scholars focused on the SCA - and able to provide expert quotes to news media.

Figure 2 Federal and local government sources

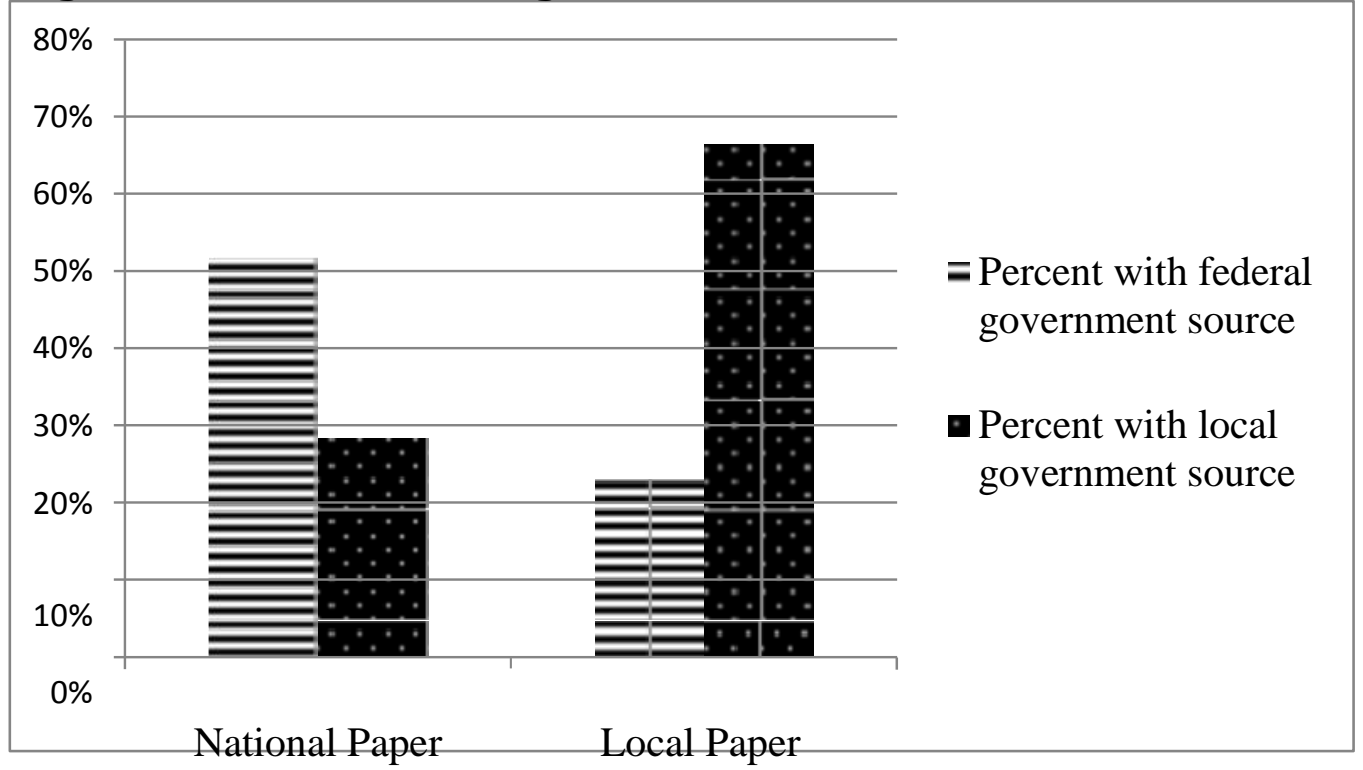

H4 compares saving money and reducing crime to improving lives in terms of the way the Second Chance Act is discussed in the newspaper. Figures 3 and 4 illustrate this comparison and also compared the local newspapers' report to the national newspapers' version.

While $\mathrm{H} 4$ predicted more discussion of both saved money and reduced crime than of improved lives as a benefit of the SCA, in fact, there was significantly more $(p<.05)$ discussion of improved lives than of saved money in national newspapers. In local papers, saved money is mentioned in $32 \%(\mathrm{~N}=45)$ and in national papers saved money is mentioned in $31 \%(\mathrm{~N}=44)$. Improved lives is mentioned in $67 \%(\mathrm{~N}=95)$ of the included local newspaper articles, and in $74 \%(\mathrm{~N}=105)$ of the included national newspaper articles.

Reduced crime was discussed significantly more $(p<.05)$ than improved lives in local papers though not in national papers. Reduced crime was mentioned in $46 \%(N=65)$ of the included articles in local newspapers. In national papers, reduced crime was mentioned in $57 \%(N=81)$ of the included articles. 
Figure 3 Reduced crime vs. improved lives

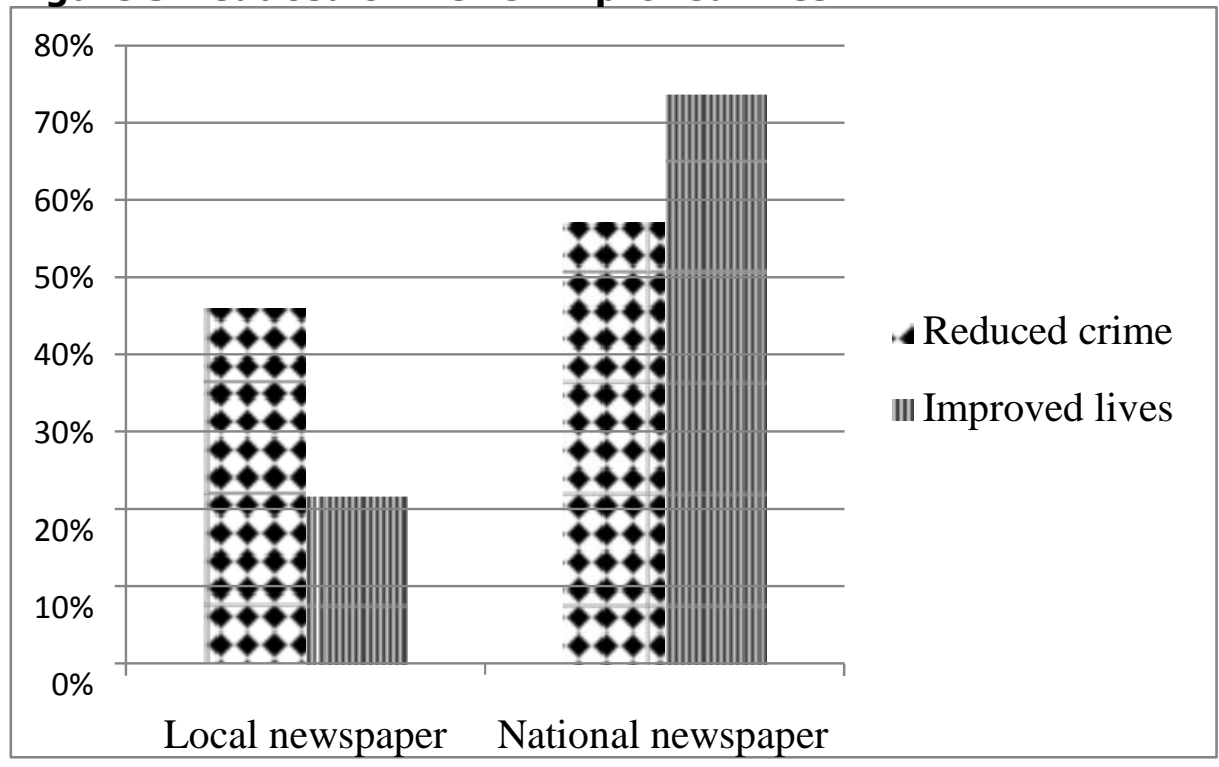

Figure 4 Saved money vs. improved lives

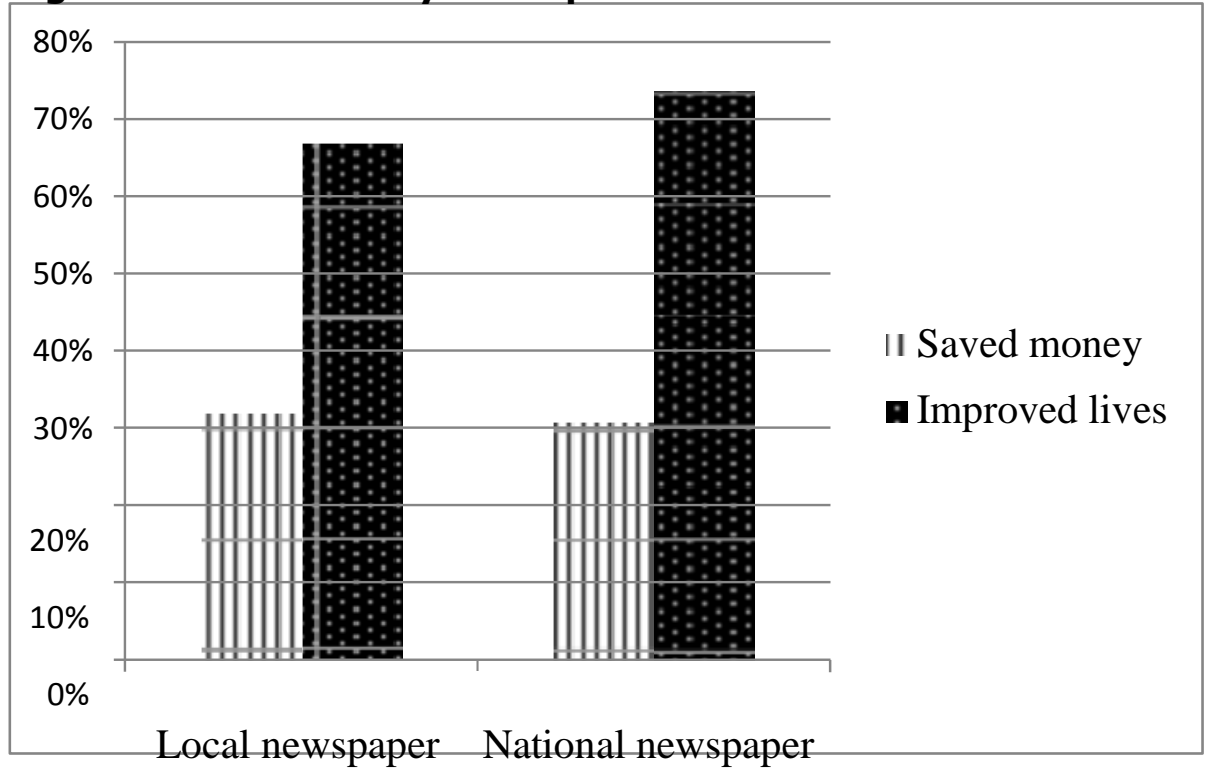

One way of determining a positive, neutral or negative report about the SCA is to look at potential positive individual outcomes of programs created or operated using SCA grants. Illustrated in Table 3, discussion of positive outcomes occurred in slightly more than $75 \%(\mathrm{~N}=76)$ of the articles and was coded as services to ex-inmates. Job training or assistance with employment activities is mentioned in $59 \%(\mathrm{~N}=84)$ of the total articles; treatment for addictions is discussed in $44 \%(\mathrm{~N}=62)$ and assistance with housing is mentioned in $35 \%(\mathrm{~N}=50)$ of the articles. The SCA specifically states that job training, addictions treatment and housing assistance are at the top of the priorities in terms of providing grant money to programs which offer such services. Skill development and education, which each are mentioned in just under $40 \%(\mathrm{~N}=57)$ of the articles, include reading skills, computer training, GED or other post- secondary education. Mentoring, which is a central part of the SCA in terms of what services the grant money will provide is mentioned in $22 \%(\mathrm{~N}=31)$ of the articles. 


\section{Discussion}

The results reported here suggest that there is limited coverage of the SCA and of exprisoner reentry in the newspaper on both a local and national level. Before discussion about how the media presents the issue it is important to note that coverage of the SCA decreased by half each year after the SCA was signed into law in 2008, even during the funding renewal years of 2009 and 2013. This is a statement about the level of importance that is assigned to reentry by the media.

How the media presents the SCA and the issue of reentry is different in local newspapers than it is in national newspapers. The results from the available articles indicate a difference in the media's framing of the SCA and the issue of reentry between local and national newspapers. Citizens are concerned about reducing crime in their communities and the local reporting reflects this concern. Nationally, the focus of news reporting is more about improving the lives of the formerly incarcerated, which is a reflection of prepared news statements from representatives of the Federal government. Saving money is of relatively equal importance in both local and national reports, with improved lives as a prioritized intended outcome both locally and nationally. The larger issue though is the need for a general shift in discussion about people exiting the prison system and returning to the community, and the culture of punishment, which would change and include conversation and planning, by collaborative partners, for how ex-inmates reenter society.

The local reporting of the Second Chance Act legislation seems to emphasize reducing crime more heavily than improving the lives of ex-inmates. In the House Judiciary Committee Report on the SCA (2007), three purposes of the legislation are identified: to reduce recidivism, increase public safety and help state and local governments better address the growing population of ex-offenders returning to their communities (HR Rep 110-140); there is no mention in this report of President Bush's call to help former inmates lead a better life. News reporters using federal government sources are merely repeating press releases rather than looking to social service, community agencies and ex-inmates themselves for progress about how their lives have been improved by increased SCA programs.

Federal government representatives provided more information as a source than community organizations and experts who are the people in the trenches of reentry. Fostering closer collaborations between universities and criminal justice agencies as well as making randomized controlled trials the rule rather than the exception in the field of offender rehabilitation (Farabee, 2007) are changes that would allow more expert information about reentry to become newsworthy information and would allow reporters to frame their stories in terms of results of expert studies, rather than regurgitating press releases. This concept combines collaborative efforts, using the research of experts in the field of reentry, focusing on the intended goal of the legislation as stated by the President.

Table 4 Positive individual outcomes

\begin{tabular}{|l|r|r|}
\hline Positive individual outcomes & & $\mathrm{N}$ \\
\hline Skill development & $39 \%$ & 55 \\
\hline Services to ex-inmates & $75 \%$ & 107 \\
\hline Drug treatment & $44 \%$ & 63 \\
\hline Job training or employment assistance & $59 \%$ & 84 \\
\hline Housing & $36 \%$ & 51 \\
\hline Education & $34 \%$ & 48 \\
\hline Mentoring & $23 \%$ & 32 \\
\hline Parenting & $6 \%$ & 9 \\
\hline Health services & $13 \%$ & 19 \\
\hline Mental health services & $23 \%$ & 32 \\
\hline
\end{tabular}


Though not included in the hypotheses, race was mentioned in a small percentage of the articles, most often in the context of racial disparity. In the studied articles, race is mentioned when the SCA was first introduced, and for the next several years; mention of race declines so much that in both 2010 and 2013 there was only 1 article each year mentioning race. 2008 is the year race is discussed most frequently; coincidently, it was the year President Obama won his first election and is also the year the reauthorization of the Second Chance Act began to provide funding via grants to communities. It is interesting to note so few newspaper articles that discuss prisoner reentry mention race, which is in stark contrast to the disparities in sentencing, and the importance of bringing race into the conversation.

Figure 6 Race

\begin{tabular}{|l|r|l|}
\hline Year & $\begin{array}{l}\text { Mention } \\
\text { of race }\end{array}$ & $\begin{array}{l}\text { Mention of Racial } \\
\text { Disparity }\end{array}$ \\
\hline 2007 & 5 & 0 \\
\hline 2008 & 12 & 9 \\
\hline 2009 & 2 & 1 \\
\hline 2010 & 1 & 1 \\
\hline 2011 & 4 & 3 \\
\hline 2012 & 2 & 2 \\
\hline 2013 & 1 & 1 \\
\hline Grand Total & $\mathbf{2 6}$ & $\mathbf{1 7}$ \\
\hline
\end{tabular}

\section{Conclusion}

Whether the public favors reducing crime, saving money or improving lives, American citizens generally support legislation which provides money to fund reentry in their community. Media framing of the SCA contributes to that support, and it provides the basis for how American citizens form opinions about public policy. This study suggested that collaboration between the agencies which are providing services to exinmates and their families and the local government must become stronger in order to comprehensively improve the lives of people as they reenter the community, which will both save taxpayers money and reduce crime. When the government and the media view reentry in terms of people first, and the goal of improving citizens' lives becomes a priority and a shift in penal philosophy can take place.

In order for the public to view the formerly incarcerated as human beings, the framing that news reporters use is crucial. Gilens concluded that the media are instrumental in shaping our understanding of the social world we inhabit; this study furthers that claim. When local newspapers report about reentry programs in their community which use Second Chance Act funds, and cite social service organizations and participants in those programs, the human element often lacking in newspaper articles about reentry can be present.

Media content has been shown to affect the importance that viewers, or in this case, readers attach to political issues. Given the extremely limited coverage the SCA received beyond the very first years of this crucial legislation, change appears to be both radically needed and extremely slow in coming. The SCA has the potential to help advance attempts to reduce recidivism while improving the lives of ex-inmates. Framing newspaper reports about reentry in terms of people, who will be returning home following prison, can contribute to increased citizen support for reentry. It is important that the media discuss reentry in terms of people- mothers, fathers, sons and daughters, neighbors and community members. 


\section{Bibliography}

Alexander, Michelle. The New Jim Crow: Mass Incarceration in the Age of Colorblindness. New York: New Press, 2010. Print. http://dx.doi.org/10.1111/j.1365-2796.2009.02206.x

Braucht, GS and Bailey-Smith, K. Reentry Surveys: A Reality Check. Corrections Today Journal. June 2006.

Bobo L. D., Thompson V. Unfair by design: The war on drugs, race, and the legitimacy of the criminal justice system. Social Research: An International Quarterly. Vol 73. pp 445-472. 2006

Clear, T.R. Imprisoning communities: How mass incarceration makes disadvantaged neighborhoods worse. Oxford: Oxford University Press. Print. 2007. http://dx.doi.org/10.1093/acprof:oso/9780195305791.001.0001

Cole, D. The Paradox of Severity in American Criminal Justice. University of Pennsylvania Journal of Constitutional Law. Vol.3, pp455-473. 2001

Cooper, Alexia, Durose, Matthew and Snyder, Howard. Recidivism of Prisoners Released in 30 States in 2005: Patterns from 2005 to 2010. US Dept of Justice. Office of Justice Programs. Bureau of Justice Statistics. April, 2014

Farabee, David Federal Sentencing Reporter, Vol 20, No. 2, Prisoner Reentry. pp136-137. Print. Dec 2007

Gest, T. Crime and Politics: Big Government's Erratic Campaign for Law and Order. Oxford Univ. New York. 2001 http://dx.doi.org/10.1093/0195103432.001.0001

Gideon, Lior and Loveland, Natalie chapter Public Attitudes Toward Rehabilitation and Reintegration in Rethinking Corrections: Rehabilitation, Reentry, and Reintegration. Sage. 2011. Print.

Gilens, Martin. Why Americans Hate Welfare Race, Media, and the Politics of Antipoverty Policy. Chicago: U of Chicago, 1999. Print. http://dx.doi.org/10.7208/chicago/9780226293660.001.0001

Grantmakers for Children, Youth and Families. Second Chance Act Summary. PDF file. Hetey and Eberhardt. Racial Disparities in Incarceration Increase Acceptance of Punitive Policies. Psychological Science. Vol. 25 pp 8.

H.R. 1593--110th Congress: Second Chance Act of 2007. www.GovTrack.us. 2007. June 3, 2014 <http://www.govtrack.us/congress/bills/110/hr1593>H.R. Rep. 110-140 (2007) Reprinted in 20 Fed. Sent. Rep. 110. 2007

Iyengar, Shanto. Is Anyone Responsible? How Television Frames Political Issues. Chicago: U of Chicago, 1991. Print. NRRC: Second Chance Act Mentoring Grants Justice Center. The Council of State Governments. csgjusticecenter.org Retrieved on May 2, 2014, from http://csgjusticecenter.org/nrrc/second-chance-act$\underline{\text { mentoring-grant-program/ }}$

Kahneman, Daniel, Slovic, Paul, and Tversky, Amos (Eds.). Judgement under uncertainty: Heuristics and biases. London: Cambridge Univ. Press. 1982. Print. http://dx.doi.org/10.1017/CBO9780511809477 
Krisberg, Barry \& Marchionna, Susan. "Attitudes of US Voters toward Prisoner Rehabilitation and Reentry Policies" FOCUS, Views from the National Council on Crime and Delinquency. (2006). Retrieved on May 23, 2014, from https://www.ncjrs.gov/App/Publications/abstract.aspx?ID=237416

Langan, Patrick and Levin, David. Recidivism of Prisoners Released in 1994 NCJ 193427 Bureau of Justice Statistics, US Dept of Justice. Office of Justice Programs. 2002. Listwan-Johnson, S., Lero-Johnson, C., Cullen, F.T., \& Latessa, E.J. Cracks in the penal harm movemement: Evidence from the field. Criminology and Public Policy 7(1) (2008): pp137-161.

Loveland, Natalie Noelle. Public's Perception on Prisoner Reentry, Reintegration \& Rehabilitation. MA thesis, 2007. New York, 2014. Print

Mellow, Jeff, and Christian, Johnna. Transitioning offenders to the community: A content analysis of reentry guides. Journal of Offender Rehabilitation Vol 47, Issue 4. (2008).

http://dx.doi.org/10.1080/10509670801992111

O'Hear, Michael "The Second Chance Act and the future of reentry reform". Federal Sentencing Reporter. Vol 20, No. 2, Prisoner Reentry. Dec. 2007. pp75-83. Print.

Park, Sunyoung. College Students' Attitudes toward prisoners and prisoner reentry. Diss. 2009. Indiana. 2014. Print

Petersilia, Joan. Parole and Prisoner Reentry in the United States. Crime and Justice. Vol. 26, Prisons, 1999 pp479-529

Petersilia, Joan. When Prisoners Return to the Community: Political, Economic, and Social Consequences. Sentencing and Corrections: Issues for the 21st Century. No. 9. November, 2000

Re-Entry Policy Council. 2007. Re-entry legislation second chance act of 2005. Retrieved April 20, 2014 from http://www.reentrypolicycouncil.org/reentry/Second chance act of 2005.aspx State of the union address. 2004. Retrieved April 20, 2014 from http://georgewbush-

whitehouse.archives.gov/stateoftheunion/2007/

Travis, Jeremy. But They All Come Back. New York: Urban Institute, 2005. Print.

Travis, Jeremy and Petersilia, Joan. Reentry Reconsidered: A New Look at an Old Question. Crime and Delinquency. Vol. 47 pp291 http://dx.doi.org/10.1177/0011128701047003001

Travis, Jeremy and Lawrence, Sarah. Beyond the Prison Gates: The State of Parole in America. Urban Institute. November, 2002

Wacquant L. Suitable enemies. Punishment \& Society, Vol 1. pp 215-222. 1999

http://dx.doi.org/10.1177/14624749922227784

Wilkinson, Reginald A. Confronting recidivism; Inmate reentry and the Second Chance Act. Reentry Today: Programs, problems and solutions. 2006. pp17-22. Print. 


\section{Appendix A Code Book}

Search Term: Second Chance Act AND prison

The Nexis search returns 185 articles for the period 1/1/2007-1/1/2014.

The search term is not $100 \%$ accurate as some articles are from Canada, and some address the Second Chances Act, and are therefore not relevant to this project. In addition, government press releases will not be included in this study and $6 \%$ are press releases included in this search.

\section{Coding Instructions}

Word Count:

Use the word count provided by Nexis if the whole piece is about the Second Chance Act; if it is a collection of letters or several smaller pieces use Word to run a word count.

Year of Publication:

- 2007

- 2008

- 2009

- 2010

- 2011

- 2012

- 2013

- 2014

\section{Hard news: 0/1}

- $\quad$ Hard news = articles that cover the Second Chance Act, dollar amount of grant awards, information about programs created or supported as a result of the grant

\section{Soft news: 0/1}

- $\quad$ Soft news = articles about fund raisers for Second Chance Act programs, auctions and the like.

\section{Incidental Mention: 0/1}

Mention of SCA without including facts or data. When an article is coded as incidental mention, coding stops here.

\section{Type of publication: $1 / 2 / 3$}

Determine the publication source of the newspaper

1. National=New York Times, Wall Street Journal, USA Today, Washington Post

2. Local=Oregonian, Baltimore Sun, Roanoke Times

3. Other=Chronicle of Higher Education, Right Vision News

\section{Type of article: $1 / 2 / 3 / 4$}

Distinguish between news articles, op-ed pieces, letters

1. News

2. Op/ed

3. Letter

4. Other

\section{Sources:}

Distinguish between the source or sources of the data provided. More than one source may be cited.

- Government: $\mathbf{0} / \mathbf{N}$

- Federal: $\mathbf{0} / \mathbf{N}$

- Local: $\mathbf{0} / \mathbf{N}$

- Expert Academic: $0 / \mathbf{N}$

- Community organization: $\mathbf{0} / \mathbf{N}$

- Program participant (ex-inmate): 0/N

- Religious or Faith Based: 0/N 


\section{- Department of Corrections: $\mathbf{0 / N}$ \\ - Other: $\mathbf{0} / \mathbf{N}$}

- Text Variable: If other source is coded, list the source.

○ $\mathbf{N}=$ number

\section{Positive Individual Outcomes:}

For individual positive outcomes, you're coding information present in an article that describes the potential positive outcomes of SCA programs created by grant money for exoffenders themselves. If there is no mention of the positive outcomes listed below, code 0 , if there is 1 sentence about positive outcomes, code 1 . If there are multiple mentions within the article of each listed positive outcome code for how many paragraphs contain discussion of that positive outcome.

- Look for information that fits into these categories:

\section{Skill development: $0 / 1 / N$}

- A program funded by a grant from the SCA will teach a (or multiple) skill(s)

Ex 1: "Barnstable County Sheriff James Cummings announced this week that his office has received a $\$ 350,000$ federal grant to establish a culinary arts certificate program at the Bourne jail and help inmates re-enter the community."

Ex 2. "In addition, they get instruction in job readiness, math and computer literacy, and life skills."

- Services to ex-inmates: $\mathbf{0 / 1 / N}$ These are medical, financial, case management

Ex 1. "The grant will fund a discharge planner, a case manager and a transitional health care coordinator to help inmates prepare for leaving the jail"

Ex. 2 "Services include case management, education, substance abuse treatment, family reunification and housing to reduce the recidivism rate in Palm Beach County."

- Drug Treatment: 0/1/N A program funded by a grant from the SCA provides drug treatment

Ex. 1. "Thanks to grants of around $\$ 600,000$, Mountain

Comprehensive Care is now offering a family-based substance abuse program at the jail."

Ex. 2. "The grant will fund a discharge planner, a case manager and a transitional health care coordinator to help inmates prepare for leaving the jail, Perry said."

- Job Training and/or help finding a job: $\mathbf{0 / 1 / N}$ This would include clothing for job search, resume building, job matching

Ex. 1. "The funding flows from the Second Chance Act of 2007, which addresses the challenges of reentry after incarceration... through the county's Workforce Investment Board, which, according to its website, helps "businesses find the right people and people find the right jobs." Ex. 2. "Cuyahoga County Office of Reentry seeks to deliver case management services to returning individuals, which would include linking them to services including job training, housing, substance abuse treatment, and health care." 
- Housing: 0/1/N This would include "Ready to Rent" programs and certificates, classes for becoming responsible tenants and actual money for rent and deposits

Ex. 1. "Currently, Second Chances funds projects in a diverse range of areas, from parenting classes to affordable housing."

Ex. 2. "Jones said S-CAP workers go with participants to help them find housing, employment or whatever else they need.

- Education: 0/1/N This would include GED, literacy or college

Ex. 1. "By providing parolees access to a two-year education, job training, counseling and substance abuse treatment program through slow integration into the community, Richards aims for Project 180 also to save taxpayer money while improving the lives of many." Ex. 2. "This team will assist the inmate with education, job training and housing after release from the jail."

- Mentoring: 0/1/N This includes specific mentor programs where ex-inmates are provided with a mentor, or a mentoring program is created using SCA funds

Ex. 1. "Defenders of the mayor's re-entry efforts highlight programs the city has implemented to provide ex-offenders with mentors and place them in temporary jobs to strengthen their prospects for fulltime employment."

Ex. 2. "Pearsall said about 80 parents will likely be involved in the mentor program, which will also refer them to other community resources and other Fighting Back programs that will benefit them."

- Parenting: 0/1/N This includes parenting classes and programs that directly address ex-inmates with their children

Ex. 1. "Through our provision of substance abuse treatment, as well as parenting and anger management classes, we feel that we can jointly provide needed services to persons who are not only in the inmate population, but are citizens who will ultimately return to Floyd County as hopefully productive members of the community and reunite with their families and not return to incarcerated status," Ex. 2. "The primary focus of the grant is Project Reconnect, which is designed to reconnect incarcerated women with their children."

- Health Services: 0/1/N This includes risk reduction, HIV/Aids/Hepatitis C education and testing, pre-natal, diet, exercise and end of life or hospice

- Mental Health: 0/1/N Any mention of mental health services is a positive outcome and coded as 1 . Dual diagnosis programs are coded as other positive outcome

\section{Positive Structural Outcomes}

For structural positive outcomes, you're coding information present in an article that describes the potential positive structural outcomes of SCA programs created by grant money for society as a whole. If there is no mention of the positive outcomes listed below, code 0 , if there is 1 sentence about positive outcomes, code 1 . If there are multiple mentions within the article of each listed positive outcome code for how many paragraphs contain discussion of that positive outcome. 
- Saving Money: 0/1/N For positive outcomes, you're coding based on a mention of a dollar amount that represents savings to the community, county, state or nation. This includes any mention of savings using dollar figures or general statements that concern money, earned or not

Ex 1. "The reduction saved the states something in the neighborhood of $\$ 150$ million in corrections costs last year alone"

Ex. 2 "Fiscal hawks have, almost inadvertently, recognized that sometimes taking care of people saves money.

Ex. 3 "And save taxpayers money by working to ensure that released offenders become productive members of our society"

- Saving or Improving Lives: $\mathbf{0 / 1 / N}$ For positive outcomes, you're coding based on a mention of lives saved as a benefit of an SCA program

Ex. 1. "Richards aims for Project 180 also to save taxpayer money while improving the lives of many

Ex. 2 "Task force leaders believe the community will save money and human capital if it can help felons establish themselves as productive citizens and keep them from re-offending."

- Reducing recidivism: 0/1/N For positive outcomes, you're coding based on a mention of reducing recidivism as a benefit of an SCA program

Ex. 1. "Encouraged by the federal Second Chance Act of 2008, which aims to promote correctional reform, several states have cut recidivism by giving newly released inmates access to drug treatment or mental health care"

Ex. 2. "This is really a faith-based approach trying to help reduce recidivism"

- Other Positive Outcome: 0/1 + Text

Text Variable: what is the positive outcome mentioned? How often is this other outcome mentioned? Dual diagnosis (mental health and addiction ONLY) is coded as other with additional text variable

\section{Amount of Award: 0/\$N}

If the article has no specific mention of the amount of grant money the state or county received, it is a 0 . If the article does mention the amount of grant money, enter dollar amount.

Ex 1: "The area's Reentry Coalition, which received about $\$ 636,800$ in operating funds last year from a federal Second Chance Act Adult Offender Recovery Program grant."

Ex. 2: "The group has obtained a federal Second Chance Act Adult Offender Reentry Planning Grant for just under $\$ 40,000 "$

\section{Quantity Served: $\mathbf{0} / \mathbf{N}$}

If the article does not mention how many people will be served by the grant, it is a 1coded 0 . If the article does mention the number of people to be served, enter the quantity mentioned

Ex. 1. "That money goes to fund a wide net of support for as many as 200 inmates per year, including services local probation and parole agencies can't provide, Kaplan said.

Transition or Reentry Program Information: 0/1 This includes any program, named or not that is created or funded using SCA funds.

If the article does not mention any program created or using SCA funds, it is a 0. 
If the article has specific mention of a program created or using SCA funds, it is a 1 .

- Text Variable: If there is mention of a program, define program by type

- Treatment for Addiction

- Parenting/Family

- Cognitive Skills such as Anger Management, Communication Skills,

Stress Management or Problem Solving.

- Support Group

- Parenting

- Housing such as "Ready to Rent"

- Job Skills, Resume Building

- Mentor

- Religious

- Other

Inmate's Family: 0/1

If the article has specific mention of the inmate's family in any respect it is a 1.

4. Ex.1 "and provided them and their families with the resources necessary to successfully rejoin society."

5. Ex. 2 "thanks to grants of around $\$ 600,000$, Mountain Comprehensive Care is now offering a family-based substance abuse program at the jail."

Women's Program: 0/1

- If the program is exclusively for women it is a 1

Youth Program: 0/1

- If the program is exclusively for youth it is a 1

\section{Multiple Agencies: 0/1}

If more than one agency works in a community, using SCA funding to provide reentry services, it is a 1.

- Ex. 1. "clothing will come from donations through the Transitional Center while skills training will be provided by staff and volunteers at the half-way house"

- Ex. 2. "Goodwill is providing a full-time employment specialist, who will also help the newly released convicts follow Corrections guidelines for where they can reside. Child and Family Services will help assess offenders for substance abuse problems. NAMI will provide mental health recovery coaches, one for men and one for women."

\section{Ex-Inmate Mention: 0/1}

If there is mention of a specific or particular ex-inmate, it is a 1.

\section{Candidate Mention: 0/1}

If the article is primarily about a candidate who either supported the SCA or did not support the SCA, it is a 1.

\section{Race: 0/1}

If there is any mention of race or races, it is a 1.

Text Variable: If there is mention of race, enter the race or races mentioned.

\section{Racial Disparity: 0/1}

If there is mention of racial disparity, or inequality based on race, it is a 1.

Text Variable: If there is mention of race, enter the race or races mentioned.

\section{Success of Program: 0/1/2}

If the article mentions program success, it is a 1.

If the article mentions lack of success, or failure of a program, it is a 2 
Portland State University McNair Research Journal 2015

Co-curriculum and ESL student success: A case study in an intensive English language program

by

James D. Mitchell

Faculty Mentor:

Dr. Kimberley Brown, Ph.D.

Citation: Mitchell, James D. (2015) Co-curriculum and ESL Student Success: A Case Study in an Intensive English Language Program. Portland State University McNair Scholars Online Journal, Vol. 9, 2015. 


\section{ABSTRACT}

This project examines the relationship between co-curricular activities and ESL student success in an intensive English language program. Extracurricular and co-curricular activities have been linked to the improvement of several factors, such as self-esteem, retention, and grade point average (Astin, 1984, 1999; Bergen-Cico \& Viscomi, 2013). Research in second language acquisition has suggested that meaningful interaction between individuals in the target language (L2) will increase a student's proficiency. Therefore, a ESL student's further involvement in an intensive English program could have a major impact on not only their academic success (operationalized in this study by the amount of classes that received a passing mark), but also their proficiency. Documented are the lived experiences of four, advanced-level ESL students who are currently enrolled in an intensive English language program on the west coast of the United States. The information gathered through face-to-face interviews and an analysis of each student's academic transcript is used to see if there is a relationship between the students' academic involvement in co-curricular activities and their perception of their success.

\section{INTRODUCTION}

Extracurricular and co-curricular activities contribute to one's academic career in ways that cannot be experienced solely in the language classroom. Extracurricular activities are defined as activities that are not part of an academic curriculum, but are offered by an academic institution. At most universities, students can expect the availability of many extracurricular activities in order to escape the hardships of academic work. Some examples of extracurricular activities include Greek life, sports, and student government and leadership. Although similar and often used interchangeably, co-curricular activities are defined as activities that are part of a classroom/program curriculum, such as science fairs, student newspapers, service learning, and mock debates. These activities act as a way for students to experience what they are learning in class in a real-world context (Klesse \& D'Onofrio, 2000).

Extracurricular and co-curricular activities fall under the category of student involvement. Student involvement has been positively linked to many aspects of academic success, such as GPA, retention, and confidence-building (Astin, 1985, 1999; Bergen-Cico \& Viscomi, 2013). To this date, there is limited scholarly literature on what student involvement means for ESL students academically, specifically students who are part of an intensive English language program. Student involvement has implications for improvement in academic success and language proficiency of English language learners (ELLs). That is, research in second language acquisition (SLA) shows that interaction is an important component for language learning. Furthermore, Gass \& Selinker (2008) argue convincingly that interaction can be used to facilitate language learning ( $p .350$ ). Given this information, my claim is that interaction and involvement together may be highly beneficial for ESL students who are enrolled in an intensive English language program, and therefore, suggest that English language learners who participate in these activities will be more successful than their peers who do not participate in such activities.

This study explores the relationship between co-curricular activities and ESL student success in an intensive English program. Although the activities housed in the IEP are designed as extracurricular activities, I define the IEP's activities as co-curricular because of the students' exposure to and usage of English. In order to show a relationship between co-curricular activities and ESL student success, I document the lived experiences of four ELLs who have participated in the IEP's offered activities. 


\section{LITERATURE REVIEW}

This literature review covers the relationship between student involvement and academic success and finishes with the introduction of my guiding research question. In this study, academic success is used to describe student's grades while student involvement is used to reflect participation within cocurricular and extracurricular activities. Student involvement is defined as "the amount of physical and psychological energy that the student devotes to the academic experience" (Astin, 1984, p. 518).

Researchers in education agree that student involvement plays a heavy role within academic success. However, there is an insufficient amount of data-driven studies within intensive English language program literature that explore the impact of extracurricular and co-curricular activity on student success. To address this gap in the research, I weave together components of general pedagogical theory, namely student involvement, and second language theory and pedagogy, where research in foreign/second language education and applied linguistics is discussed.

\section{General Pedagogical Theory}

Many educators believe that student development cannot be achieved only in the classroom. Astin (1984) states "a particular curriculum, to achieve the effects intended, must elicit sufficient student effort and investment of energy to bring about the desired learning and development" (p. 522). Researchers note that student responsibility, initiative, and self-directedness in academic achievement are important to improve the quality of a student's undergraduate experience (Kuh et. al, 1991). Xiao \& Luo (2009) discovered that the students in their study found English cocurricular activities are not only helpful in their English practice, but they also help create autonomous learning. Therefore, being involved in extracurricular and co-curricular activities allows students to hold agency over their academic trajectory. This has implications for ESL students attending university, particularly in regards to the theory of student involvement.

Astin's theory of involvement (1984) suggests that students learn by immersing themselves in the academic and social aspects of the collegiate experience. The theory "emphasizes active participation of the student in the learning process" (p. 522). In the development of this theory, extracurricular and co-curricular activities were positively linked to retention among undergraduates. On factors that contributed to student retention, Astin states:

It turned out that virtually every significant effect could be rationalized in terms of the involvement concept; that is, every positive factor was likely to increase student involvement in the undergraduate experience, whereas every negative favor was likely to reduce involvement. In other words, the factors that contributed to the student's remaining in college suggested involvement, whereas those that contributed to the student's dropping out implied a lack of involvement. (1984, p. 523)

Additionally, Astin states that his theory is more concerned with "the behavioral mechanisms or processes that facilitate student development" (the "how" of student development as opposed to the "what" of student development) (p. 522). He claims that "the greater the student's degree of involvement, the greater the learning and personal development" (1996, p. 124). Astin also found that student involvement serves as "a powerful means of enhancing almost all aspects of the undergraduate students' cognitive and affective development" (1996, p. 126), with the most prominent forms being academic involvement, involvement with faculty, and involvement with student peer groups. Research has reported that attendance in college and in college activities helps students with their self-esteem, self-confidence, and leadership skills (Astin, 1984; Klesse \& D'Onofrio, 2000). ELLs are no exception to this statement. Xiao \& Luo's (2009) suggest that "proficient students actively participate in the co-curricular activities because they have more self- 
confidence" (p. 245). Therefore, active ELLs in an IEP may experience heightened self-esteem by participating in activities on campus.

In a study conducted by Bergen-Cico and Viscomi (2013), they found that there is a positive association between attendance at campus co-curricular events and GPA. Their quantitative study shows two cohorts that were split into three groups each based on their level of co-curricular involvement. The study showed that students who have attended a mid-level range of events (5-14 over the span of 8 semesters) had the highest GPAs out of the three groups.

\section{Second Language Pedagogy and Theory}

Research has consistently supported that students need to practice the target language in order to achieve proficiency (Savignon, 1997; Xiao \& Luo, 2009). The theory of student involvement can have implications for ELLs. Astin (1999) states that students gain knowledge by devoting their time to academic activities:

According to the theory, the extent to which students can achieve particular developmental goals is a direct function of the time and effort they devote to activities designed to produce these gains. For example, if increased knowledge and understanding of history is an important goal for history majors, the extent to which students reach this goal is a direct function of the time they spend at such activities as listening to professors talk about history, reading books about history, and discussing history with other students. Generally, the more time students spend in these activities, the more history they learn. (p. 522-523)

This type of involvement for ELLs leads directly into improving communicative competence, which is defined as the competence or ability to communicate (Canale \& Swain, 1980; Canale, 1983; Hymes, 1972; Oxford, 1990). There are four main components of communicative competence: linguistic, sociolinguistic, discourse, and strategic competence (Brandl, 2007; Canale \& Swain, 1980). Linguistic competence refers to knowledge of grammar and vocabulary. Sociolinguistic competence refers to the ability to say the most appropriate phrase or word in a certain situation. Discourse competence refers to the ability to start, contribute to, and end a conversation in a consistent and coherent manner. Strategic competence refers to the ability to communicate effectively and repair communication when problems arise (Brandl, 2007; Canale \& Swain, 1980).

The learning strategies of ELLs contribute to developing communicative competence. Learning strategies, as defined by Oxford (1990), are the "steps taken by students to enhance their own learning (p. 1). Oxford (1990) states that the "development of communicative competence requires realistic interaction among learners using meaningful, contextualized language. Learning strategies help learners participate actively in such authentic communication" (p. 8). This kind of interaction may eventually lead to better communicative competence, and therefore, lead to "improved proficiency and greater self-confidence" (p. 1).

Oxford (1990) describes six types of learning strategies. These six types fall under two categories: direct and indirect strategies. Direct strategies require the learner to use a great deal of mental processing of a language, while indirect strategies act as the "business management" of language learning strategies. Table 1 shows the different types of direct learning strategies, while table 2 shows the different types of indirect learning strategies. Direct and indirect strategies support each other in the contribution to communicative competence. Oxford (1990) uses a theatre analogy to explain how these strategies support each other:

The first major class, direct strategies for dealing with the new language, is like the Performer in a stage play, working with the language itself in a variety 
of specific tasks and situations... The second major strategy class- indirect strategies for general management of learning-- can be likened to the Director of the play... The functions of both the Director and the Performer become part of the learner, as he or she accepts increased responsibility for learning. (pp. 15-16)

Table 1: Direct learning strategies. Taken from Oxford (1990).

\begin{tabular}{|l|l|l|}
\hline \multicolumn{1}{|c|}{ Memory } & \multicolumn{1}{c|}{ Cognitive } & Compensation \\
\hline Creating mental linkages & Practicing & Guessing intelligently \\
\hline Applying images and sounds & $\begin{array}{l}\text { Receiving and sending } \\
\text { messages }\end{array}$ & $\begin{array}{l}\text { Overcoming limitations in } \\
\text { speaking and writing }\end{array}$ \\
\hline Reviewing well & Analyzing and reasoning & \\
\hline Employing action & $\begin{array}{l}\text { Creating structure for input } \\
\text { and output }\end{array}$ & \\
\hline
\end{tabular}

Table 2: Indirect learning strategies. Taken from Oxford (1990).

\begin{tabular}{|c|c|c|}
\hline Metacognitive & Affective & Social \\
\hline Centering your learning & Lowering your anxiety & Asking questions \\
\hline $\begin{array}{l}\text { Arranging and planning your } \\
\text { listening }\end{array}$ & Encouraging yourself & Cooperating with others \\
\hline Evaluating your learning & $\begin{array}{l}\text { Taking your emotional } \\
\text { temperature }\end{array}$ & Empathizing with others \\
\hline
\end{tabular}

There are two relationships between literature on learning strategies in ESL and the theory of student involvement- the first being learner autonomy. Oxford states that language learner strategies encourage students to have self-direction in communicating. She states:

Self-direction is particularly important for language learners, because they will not always have a teacher around to guide them as they use the language outside the classroom. Moreover, self-direction is essential to the active development of ability in a new language...Learner self-direction is not an "all or nothing" concept; it is often a gradually increasing phenomenon, growing as learners become more comfortable with the idea of their own responsibility. (1990, p.10).

Self-direction is important not only for students in an IEP, but also for university students, which brings back the theory of student involvement. As discussed earlier, students to an extent hold agency over their academic trajectory. This type of self-direction has the potential to improve a student's undergraduate experience. Second, English language students will achieve greater confidence by having self-directedness (1990). This means that for ELLs, better learning strategies lead to students participating more often, and by participating in activities on campus, students become more confident and have higher self-esteem (Astin, 1984; Klesse \& D'Onofrio, 2000).

The research reviewed shows several key points that are relevant to my study: 
1. Student participation leads to better student learning and development (Astin, 1984, 1996).

2. English language learners who participate in co-curricular activities have greater confidence. Evidence has shown that ELLs generally find that student activities can help enhance their language abilities, although there are exceptions (Xiao \& Luo, 2009). Achieving confidence is a language learning strategy that leads to better self-directedness, and therefore, can lead to better communicative competence. For all students, student responsibility, initiative, and self-directedness in academic achievement are important to improve the quality of a student's undergraduate experience (Kuh et. al, 1991).

3. There seems to be a positive relationship between GPA and student campus event participation (Bergen-Cico \& Viscomi, 2013).

4. ELLs need to be exposed to meaningful, contextualized language outside of the classroom (Oxford, 1990). Devoting time to co-curricular activities helps the student acquire more knowledge of the subject that they are practicing. (Oxford, 1990; Astin, 1984; Xiao \& Luo, 2009).

With these points in mind, I arrive at my guiding research question: What is the relationship between ESL student success and co-curricular activities?

\section{SETTING AND CONTEXT}

As stated earlier, this study took place at an urban university in the Pacific Northwest. The IEP that is housed at the university is a comprehensive, five-level English program that prepares students to take courses at the college level. Before students start in the IEP, the program gives the students a placement test to determine where they should start in the program. The IEP follows the university's quarter-based system, giving the academic year a fall, winter, spring, and summer term. The program offers five tracks for its students: pre-entry, foundational, communication and culture, undergraduate preparation, and graduate preparation.

The IEP's pre-entry track is designed for students who have very limited English ability. Students in the pre-entry program are expected to be in class 23 hours a week. Pre-entry track students are given extra tutoring support to account for their low English abilities. Students in this program are expected to take grammar/writing, speaking/listening, reading, and American culture and academic life. All pre-entry level students must finish the track in two terms. The end of this track will lead into the foundational track.

The IEP's foundational track is for beginning level students who have basic English skills. The foundational track consists of levels 1-3. Students spend less time in class than the pre-entry level at 18 hours a week, but they spend more time on homework at about 15-20 hours a week. After students successfully complete one level, students continue to the next level. In addition to classes on grammar/writing, speaking/listening, and reading, students must choose one elective, which the IEP calls "skill enhancement courses." Students in this level can choose from classes such as computer skills, pronunciation, or academic vocabulary. After students pass level 3, they can choose the academic track (undergraduate and graduate preparation) or the communication and culture track.

The undergraduate and graduate preparation tracks constitute levels 4 and 5 in the IEP. Up to 24 credits given at levels 4 and 5 in the IEP can be transferred over to the university for undergraduate elective credit. Both undergraduate and graduate students take the same level 4 English classes: advanced English grammar, guided research writing, academic reading, understanding academic lectures, and an elective. At level 5, undergraduate students are expected to take Grammar and Editing for Academic Writing, Independent Research Writing, Advanced 
Academic Reading, an elective, and a choice between Discussion Skills or Public Speaking. Graduate students are expected to take an elective, Graduate Oral Communication, Graduate Reading Strategies, Graduate Research and Writing, and a choice between Grammar and Editing for Academic Writing or a language proficiency test preparation course. After completion of level 5, the students can enter the university without taking the TOEFL, a standardized test of English language proficiency required for admission into the university.

The communication and culture track is an alternative track for students who are part of the IEP that are not seeking entry into the university. These students are usually part of a study abroad program and know English well enough to take the courses. These classes teach students more about American culture and help students develop their confidence in communicating. In addition, the classes still focus on English skills, but they are explored through mediums such as movies, music, books, and TV shows. Such courses include social media: interacting online, multimedia listening, cultural themes in reading, practically speaking: conversational English, and communication through volunteering.

In the pre-entry and foundation classes (pre-entry through level 3 ), grades are given only as pass or no pass (P/NP). To receive a $P$ in their classes, the students have to (a) complete all of their work and (b) receive at least a $70 \%$ in their classes. Classes in levels 4 and 5 receive grades on the A-F scale. The scale depends on the class and on the teacher.

Activities in the IEP are open to all students (pre-entry to level 5, undergraduate and graduate). In addition to sponsoring activities that are part of solely part of the program, the program sponsors events with other departments at the university. Below is a description of the activities and events sponsored by the IEP.

Conversation Practice - The IEP hosts a volunteer conversation partner program for its students. IEP students are paired up with student volunteers who are L1 speakers of English to practice their conversational English skills. The conversation partner program offers three options for its students:

- An individual conversation partner session where students can sign up for two, 30 minute sessions a week. This is hosted in the department's own "conversation room" every week-day during their business hours.

- A group conversation session every Tuesday and Thursday during lunch hours. Conversation partners facilitate this event, welcoming any IEP student who wishes to come and socialize.

- An individual conversation partner program where advanced IEP students are paired up with volunteer university students. The pairs of students meet at least once a week either on - or off-campus.

Field Trips - The IEP sponsors a variety of trips, seasonal and year-round, to various locations and festivals around the Pacific Northwest. Additionally, the IEP purchases tickets for and transports students who wish to attend to the Portland Blazers' games. IEP students, several faculty members, and conversation partners attend the games together.

International Coffee Hour - Coffee Hour is sponsored by the IEP and the university's Organization of International Students. Coffee Hour takes place once a week for three hours. IEP students have a chance to meet and converse with university students.

Parties - The IEP hosts an end-of-the-term party every term as well as a welcome party for new students who are entering the program. Additionally, in conjunction with the Office of International Students, the IEP hosts an annual Halloween party, where students are encouraged to dress up and attend. All students in the program are invited to attend these events. 


\section{METHODOLOGY}

There is a dearth of articles focusing on the relationship between student activities and student success in the language learning field. These studies also appear to depend on quantitative techniques (Bergen-Cico \& Viscomi, 2013). However, as there are many factors that influence a student's performance in school, such as family trouble, relationship problems, sometimes rich qualitative accounts weave these variables together. Thus, I decided to use the case study methodology for this study. In order to find themes among each participant and gender, I decided to interview four students- two male and two female.

It was pertinent to my study that I document the lived experiences of participants who have been in the IEP long enough that there would be significant documentation of student involvement. It was also important that I recruit people with enough English ability to be able to describe their experiences in the IEP. Therefore, I recruited students who met the following criteria:

1. Students had to be currently enrolled in the IEP.

2. Students had to be in the program since at least level 2.

3. Students had to currently be in levels 4 or 5.

To find participants for my study, I worked with the Student Life Coordinator of the IEP. The coordinator's job is to plan, manage, and run all of the supplemental activities in the IEP. Additionally, it is their job to manage the activities budget; hire, manage, and supervise the activities office team of student workers and staff; and plan and arrange the new student orientation each term. The coordinator orally spoke to students that she knew who might be willing to participate in my research. Because the coordinator knew these students, they were students who participated frequently in the IEP's activities. I reached out through e-mail to six students who agreed through word-of-mouth to take part in my research. After sending the e-mail, I received a response from four IEP students- two male and two female. All but one, a female participant, met the criteria that I had set for the research. The coordinator ran out of people she knew who fit my criteria, so I found my last participant through another one of my participants.

Through my e-mails to the participants, I asked them if they were willing to participate in a faceto-face interview. Upon their agreement to participate, I asked them to give me their available times in order to reserve a private study room in the university library. In the e-mail, I also included a copy of the consent form for them to read and sign. I wrote that I wanted to send it ahead of time for them to read, but I would review it in our meeting together and address their questions about it in person.

Instead of asking for a transcript, which would have cost the student money and would have taken weeks to be delivered, I asked each participant to prepare a copy of their Degree Audit Reporting System (DARS) report. A DARS report is a document showing a student's progress towards completing their academic degree and displays other academic such as class grades, major and overall GPA, and transfer credits.

For each interview, I reserved a private study room in the university library for an hour and a half. Although I stated in each e-mail that the interview would take only 30-45 minutes, I reserved the study room for longer in order to complete field notes after each interview. The interviews were not recorded. Instead, I took extensive notes while my participants were answering my questions. After the interview concluded, I continued writing things that I might have remembered or observations during our interview that I did not have a chance to write while they were speaking. 
The interviews were semi-structured. The questions I asked aimed to elicit information about their lives, academic life, their friends, and the ways in which they approach their work. This information was used to see if there were parallels between their involvement in activities and their academic history. I also asked each participant for a copy of their Degree Audit Reporting System (DARS) report, which reflects the grades they received in their classes.

\section{Limitations}

This study does not come without its own limitations. Firstly, this study was designed and conducted in a very small time frame, given that it was part of the McNair Scholars Program. My proposal was submitted to the Internal Review Board in April 2014, and I received approval in June 2014. A study with a longer time period would have created more thorough and detailed results. This information given, the narratives of participant provided in the next section would have been richer if I had interviewed my participants more than once and if I had recorded the interviews and not have just relied on note-taking. However, I am confident that I noted the most important information possible during the 30-45 minute interviews- all of which is presented in my narratives.

\section{NARRATIVES}

This section documents the narratives of all four participants: Will, Grace, Jack, and Karen. In each narrative, I have (1) described their daily life and interests; (2) described the people each participant interacts with on a day-to-day basis; (3) documented their participation in the IEP's activities, when they started participating in each activity, and how often they have participated; (4) listed the grades they have received in the IEP; and (5) documented their perception of their performance in the IEP as well as any reasoning they have given as to why they received a less than satisfactory/failing grade. Following the narratives, I will give my own interpretation of the data as well as emerging themes I have noticed from each interview.

\section{Karen}

Karen is a female student in the IEP. During the summer 2014, she was enrolled in the level 4 classes required for undergraduate and graduate students. She started in the fall of 2013, placing in level 1 of the IEP in speaking/listening and reading. In grammar/writing, she placed in level 2. At the time of our interview, she had just moved into a dormitory on the university campus, living with an American roommate. Before her move, she was living with a host family since October 2013, commuting to campus every day.

Karen is a sports lover. Much of her time outside of school is spent participating in sports related activities. She stressed her love of attending and watching National Basketball Association (NBA)/Major League Baseball (MLB) games to me during our interview both locally and regionally. Twice a week, she attends softball games with some of her L1 English-speaking friends. She states that because of her frequent attendance at local softball games, she is well-versed in speaking about softball in English. She also enjoys being physically active, participating in sports and Zumba on campus when she has the time.

Unsurprisingly, the majority of people that Karen encounters on a day-to-day basis are L1 speakers of English: teachers, roommate, host family, and friends of hers, all of whom are American. However, most of her friends are L2 speakers of English, with the majority of them being from countries outside of her own. In regards to this, Karen stated that she enjoys learning about culture and ideology of other countries, which is one of her favorite things to learn. She and her friends outside of her native country will discuss various aspects of their own respective cultures. 
Since starting in the program, Karen has participated in a variety of different activities the IEP has to offer. Table 3 shows Karen's participation in IEP activities. These activities include the pumpkin patch trip, the Halloween party, several trips to the mall, three Portland Blazers games, two class trips to Seattle, a trip to Mt. Hood, and a trip to the Tulip Festival. Her further participation in IEP activities include participating in the conversation partner program, which she started participating in during winter term. She also attends the International Coffee Hour, an activity that she really enjoys, approximately three times a term.

Table 3: Karen's Participation in Activities.

\begin{tabular}{|l|l|}
\hline \multicolumn{1}{|c|}{ Activities } & \multicolumn{1}{|c|}{ Times Participated } \\
\hline Conversation Partner Program & Since winter 2014 \\
\hline International Coffee Hour & $\sim 3$ per term \\
\hline Field Trips & $\sim 8$ \\
\hline Parties & $\sim 3$ \\
\hline
\end{tabular}

Karen states that she has a strong determination to learn English. After the no pass she received fall term, she dedicated herself to interacting more in English. Therefore, she started participating in the IEP activities more often. During our interview, she said that going to Coffee Hour was one of her favorite activities for this reason. Her love for learning about new cultures allowed her to meet and interact with people from other countries outside of her own at this event. She stated during our interview that she could not attend this event every time because of her schedule, which is why she attends only about three times a term. Frequently at Coffee Hour, university students who are studying her L1 will try to talk to her using her L1, but she resists using it because of her determination to use English. She thinks that using this strategy has helped her English greatly, though she did not give specific reasons.

Karen's exception to her "English-only" rule is her occasional conversations with her friends, conversations with her family over Skype, and her conversation partner. With her L1 friends, she uses her native language only when she is frustrated and cannot find the words to say exactly what she wants to say. I asked her to estimate the amount of times she does use her L1. She stated that she only uses it about $10 \%$ of the time.

Since winter 2014, Karen has been participating in the conversation program in the IEP. Her first conversation partner was a Mexican-American who spoke English and Spanish as her L1. They met frequently throughout winter and spring term, going to restaurants and bars. Karen was very curious about Mexican culture, so her partner would teach her different aspects about it. It was not until late spring/early summer 2014 that Karen switched conversation partners and received a conversation partner who is an American learning Karen's L1. Because of this, Karen is more lenient with her "English-only" rule.

Karen claims that she was not "a good student" when she first started in the IEP in fall 2013. Table 4 shows a list of grades that Karen has earned thus far in the IEP.

Table 4: Karen's Grades in the IE 


\begin{tabular}{|l|l|l|l|}
\hline \multicolumn{1}{|c|}{ Class } & Fall '13 & Winter '14 & Spring '14 \\
\hline Level 1 - Reading & P & & \\
\hline Level 1 - Speaking/Listening & P & & \\
\hline Level 2 - Grammar/Writing & NP & P* & \\
\hline Level 2 - Reading & & P & \\
\hline Level 2 - Speaking/Listening & & P & \\
\hline Level 3 - Reading & & & P \\
\hline Level 3 - Speaking/Listening & & & P \\
\hline Level 3 - Grammar/Writing & & & P \\
\hline Skills Enhancement Electives** & P & P & P \\
\hline
\end{tabular}

*Class retaken for a passing grade; $* *$ Different class for each term.

Since starting in the IEP, she has only failed one class, which was during her first term (Fall '13) in the IEP. In addition to failing a class, she claimed that she had almost failed her other classes because of her lack of English participation. However, the following term (Winter '14). she retook the class and passed it. When I asked her about why she thinks she failed the class, she told me that it was the fact that she barely attempted to speak in English during her first term. In the beginning of her time in the IEP, she said that before she could not retain knowledge about English. Her lack of English knowledge discouraged her, which led her to only interact with other speakers of her native language. Karen claims that because of her lack of English interaction, combined with a really difficult teacher, lead her to getting an unsatisfactory grade in level 2 grammar/writing. I asked Karen if she thought she was a good student presently, to which she said yes. Nowadays, however, Karen has a better grasp of English and feels comfortable participating in activities.

\section{Jack}

Jack is a male, level 5 graduate student in the IEP. During the summer 2014 term, he described his days as being long, spending about 5 hours in class a day. When Jack started the IEP, he was placed in the level 2 reading and speaking/listening classes; however, he was placed in the entry level grammar/writing class. After his first term, he skipped grammar/writing level 1, slightly closing the gap between this skill area and the others. In terms of work, Jack usually completes his homework immediately after his classes. Once he is finished, he goes to the campus recreation center, where he goes usually goes swimming or plays basketball with his friends. On the weekends and holidays, Jack takes a lot of time for himself. His favorite hobby is travelling and exploring, so he uses this time to go on various trips, ranging from the beach to a city he has never explored. On Sundays, Jack prepares for the long week by relaxing and finishing his homework for the week.

Instead of transferring into the university after he finishes the IEP, Jack plans on transferring to a university in the mid-west to start his master's degree. In the spring of 2014, after three completed terms in the IEP, he took the Test of English as a Foreign Language (TOEFL). He passed 
the exam, and therefore does not need to finish the program. However, he decided to stay and take the classes in the IEP to help his English skills.

Jack has many friends in many different circles. When I asked him to elaborate on who his friends are, he stated that about half of the people he interacted with were L1 English speakers and the other half were L2 English speakers. He knew some of his friends from his native country before he came to the U.S. to learn English. In addition to his friends he knew prior to coming to the states, he has many friends who he met in the IEP that speak his L1. He interacts with them frequently in their L1. Although he has many friends that speak his L1, Jack interacts with many of his classmates outside of his L1 as well. He is a very popular student with many friends in other language circles. Although it seems like he speaks in his native language quite often, he stated that he makes in effort to interact in English with his classmates, hanging out often with his other L2 English friends.

Jack has a large circle of L1 English friends as well, all of whom are American. He lives on campus with two L1 speakers of English, both of whom he considers good friends. He also said that he talks to his teachers quite a bit, even becoming friends with one of them after his class ended. Jack also has a conversation partner. With his conversation partner, they often discuss class, presentations, and papers. Jack has asked his conversation partner, as well as his other L1 English friends, to correct his grammar if it is wrong. He notes that when he first came to the states, he was corrected all of the time. Nowadays, he says, he is not corrected as much anymore.

Jack still communicates often in his L1, unlike Karen who tries not to use hers at all. However, in the presence of someone who does not speak his L1, he reports that he does not use it at all. He is afraid of looking rude and excluding people from a conversation. Therefore, he will use English instead.

Jack is a very active participant in the activities the IEP has to offer, which is shown in table 5. Starting immediately after his entrance into the IEP in the summer of 2013, he has participated in many of the trips, stating that it was the "best part" of the IEP. He has generalized that he has attended every trip, except one during winter term. These field trips include several class trips to the mall, Mt. Hood, a pumpkin patch, the Tulip Festival, and several trips to the beach. He has also attended three Portland Trail Blazers games and has gone to Seattle twice with his class.

Table 5: Jack's Participation in Activities.

\begin{tabular}{|l|l|}
\hline \multicolumn{1}{|c|}{ Activities } & \multicolumn{1}{|c|}{ Times Participated } \\
\hline $\begin{array}{l}\text { Conversation Partner } \\
\text { Program }\end{array}$ & Since Summer 2013 \\
\hline International Coffee Hour & $\sim 2$ per term \\
\hline Field Trips & $\sim 10$ \\
\hline Parties & None Reported \\
\hline
\end{tabular}

As a participant in the conversation partner program, Jack has his own conversation partner. Before that, he would go into the drop-in sessions to converse with some of the program's employees. Additionally, he talks to the activity coordinator and their assistant quite a bit. In fact, Jack reports that he makes an effort to talk with any L1 English speakers he can. For example, when going to the Portland Blazer's games, he tries to sit next to the activity coordinator or any 
conversation partner as opposed to an L2 English speaker. He also attends Coffee Hour from time to time, following this same strategy.

Jack was very adamant about how he was not a good student- his reason being that he "hate[s] academic English. [He] passed [his] classes because [he has] to." Table 6 lists the grades that he received over the past four terms he has already completed in the IEP.

Table 6: Jack's Grades in the IEP

\begin{tabular}{|c|c|c|c|c|}
\hline 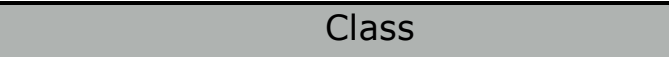 & Su '13 & Fall '13 & Winter '14 & Spring '14 \\
\hline Grammar/Writing Level E & $P$ & & & \\
\hline Reading Level 2 & $P$ & & & \\
\hline Speaking/Listening Level 2 & $P$ & & & \\
\hline Grammar/Writing Level 2 & & $P$ & & \\
\hline Reading Level 3 & & $P$ & & \\
\hline Speaking/Listening Level 3 & & $P$ & & \\
\hline Grammar/Writing Level 3 & & & $P$ & \\
\hline Academic Reading Nonnative Speaker & & & $\mathrm{F}$ & $A-*$ \\
\hline Understanding Academic Lectures & & & $\mathrm{C}$ & \\
\hline Advanced English Grammar & & & & $\bar{D}$ \\
\hline Guided Research Writing & & & & $B$ \\
\hline Skills Enhancement Course** & $P$ & $P$ & $\mathrm{P} / \mathrm{P} * * *$ & $P$ \\
\hline
\end{tabular}

*Class retaken for a passing grade.; $* *$ Different class for each term.; *** Two classes were taken that term.

I asked specifically about winter term 2014, where he received an F and a C, but received a $\mathrm{P}$ in the other three classes he was taking at the time. During winter term 2014, he says he was "really busy." I asked what he meant by that, and he stated that he was having family trouble at the time. I made the conscious decision not to ask him specifically about what was happening at the time, but he did state it was severe enough that he was not focused on school that term. When he retook the class in the spring 2014 term, he completed the class with an A-. When I asked about the D he received in his grammar class during the spring term, he said that he hated grammar classes, which might explain his placement in the entry level grammar/writing class during his first term in the program. He stated that lost the motivation to do well in this class because he passed the TOEFL that same term.

When I asked him if the activities in the IEP helped him, he did not let me finish the question before he gave a very excited "Yes!" He went on to state that the IEP activities gave him the motivation to want to learn English. The people he has encountered in various activities help him 
"keep in the mood for speaking English". Many of his friends who are a part of his L1 do not participate in these same activities. They do not interact with people the way he does, and according to him, he says he is much better at English than them.

\section{Will}

Will is a level 5 student taking the undergraduate preparation courses in the IEP. Starting in fall 2014, he was placed in the foundational track of the IEP after only having prior English instruction for only six months before he came to the U.S. from his native country. He placed in the level 1 grammar/writing and speaking/listening classes. Instead of placing in level 1 for reading, he placed in level 2.

On an average day, Will wakes up every day at 6 a.m. He goes to the gym every morning as soon as it opens. After the gym, he goes back to his dorm to take a shower and eat breakfast. He finishes just in time for his first class every morning at 9:15 a.m. Once his classes end for the day at around 3 p.m., he goes home and calls his mother. After their conversation, he does about two hours of homework, which varies day-to-day. During his homework, he watches cartoon shows. If he is not watching cartoons, he will listen to music to also help him do his work. He finds that the music helps him relax.

After his homework is complete, he is dedicated to learning something new about his academic major in English, varying from vocabulary to content. In his free time, Will reports that he does a great deal of rollerblading, either alone or with his friends or roommates. On the weekends, he goes to the gym more often, rollerblades, and makes a point to go to a new place every weekend. If he does not make it to a new place, he will go to the river to hang out with some of his friends.

Will considers both of his roommates friends of his. Both roommates are L2 speakers of English, one of them being a regular university student and the other being a student in the IEP. He told me that he had two very close friends in the IEP, both of whom are not from his native country. He is also friends with many students who are studying in the IEP. Will only knows two L1 English speakers, one of which is an acquaintance and the other is a friend of his. Will interacts in his L1 when he is alone with other people who speak his L1. Otherwise, Will makes it a point to speak in English as much as possible.

Will made it very clear to me that he "came here to study. So, [he has] to study." The ways in which Will went about doing his work are worth mentioning. On days when he needs to do homework and he is with his friends, he makes sure that he only speaks English when doing any of his homework. Often, if he is doing homework with his friends, he finds himself tutoring his friends.

Although Will is dedicated to getting his work done, he is still a very active participant in the IEP activities. Will values the activities that are hosted by the IEP greatly. Table 7 shows Will's participation in these activities. Will has gone on many of the class trips, including trips to the mall, Seattle, the pumpkin patch, Mt. Hood, Multnomah Falls, and the Tulip Festival. In addition to field trips, he has attended "six or seven" Portland Trail Blazers games, the fall and winter end-of-theterm parties, and the Halloween party. Will only attended Coffee Hour once, which was during the spring 2014 term.

Table 7: Will's Participation in Activities.

\begin{tabular}{|c|l|}
\hline \multicolumn{1}{|c|}{ Activities } & Times Participated \\
\hline Conversation Partner Program & Since fall 2013 \\
\hline
\end{tabular}




\begin{tabular}{|l|l|}
\hline \multicolumn{1}{|c|}{ Activities } & Times Participated \\
\hline International Coffee Hour & 1 \\
\hline Field Trips & $\sim 14$ \\
\hline Parties & $\sim 3$ \\
\hline
\end{tabular}

Although he will speak his L1 when his friends are around, Will makes it a point to speak only in English during the field trips, regardless of if his friends are around. Will stated without hesitation that the conversation partner program was the "best activity" in the IEP. He is a very active participant, starting immediately since his arrival in the fall. Since the fall, he stops in twice a week for a drop-in session during his lunch hours. He also has a personal conversation partner. Will stated that he used to be very anxious about speaking, but he no longer feels this anxiety, which he thinks is because of the conversation partner program.

Will received nothing less than an A- in his classes. Table 8 lists the courses he has taken and the grades that he has received thus far.

Table 8: Will's Grades in the IEP

\begin{tabular}{|l|l|l|l|}
\hline \multicolumn{1}{|c|}{ Class } & Fall '13 & Winter '14 & Spring '14 \\
\hline Grammar/Writing Level 1 & P & & \\
\hline Speaking/Listening Level 1 & P & & \\
\hline Reading Level 2 & P & & \\
\hline Grammar/Writing Level 2 & & P & \\
\hline Speaking/Listening Level 2 & & P & \\
\hline Reading Level 3 & & P & \\
\hline Advanced English Grammar & & & A \\
\hline Guided Research Writing & & & A \\
\hline Academic Reading for the Nonnative Speaker & & & A- \\
\hline Discussion Skills for the Nonnative Speaker & & & A \\
\hline Skills Enhancement Courses* & & P & P \\
\hline
\end{tabular}

*Different class for each term

Although Will started out in speaking/listening levels 1 and 2 in the fall and winter terms, he skipped over levels 3 and 4 . He told me that level 2 was incredibly boring and not challenging. Even after skipping over those two speaking/listening classes, he managed to make an A in his level 5 listening course in the spring 2014 term. He even notices that among his classmates, he 
can speak better than many of them, which facilitated his decision to skip those levels. He felt ready to be a part of the more advanced class.

Despite his grades, Will does not think of himself as "a good student." He states that he "knows students who are better than (him)." A part of the reason for this thought is because of his English background. Many of the students he is comparing himself to started learning English long before entering the IEP, according to him. Since he only started learning English six months prior, he feels as though he cannot compare on an intellectual level.

Will believes that the activities hosted by the IEP helped him greatly with his academics and his language proficiency. He states that he could not speak in English at all before he started the IEP, and the activities helped him further his English education and speaking ability.

\section{Grace}

Grace is an undergraduate student taking level 5 classes in the IEP. Like Will and Karen, Grace began classes in fall of 2013, placing entirely in level 1 classes. She is a dedicated student who spends weekdays studying and completing homework. Grace is so dedicated that she was able to skip the level 3 classes in the program. She finds small breaks when she can, however, going to the campus bar to enjoy $\$ 1$ drinks with her friends on Thursday evenings, watching TV at night after homework, and taking lunch breaks with friends. Although she studies hard during the weekdays, she uses the weekends for fun. On Saturday mornings and evenings, she likes to visit parks and gardens. At night, she stated that she likes to go to dorm parties with her friends. If there is no dorm party that night, she goes to the bar instead. Because of her weekend partying, she likes to wake up late on Sunday. With the rest of her time that day, she works on projects and studies for class. About twice a week, she talks to her family. Before this term, she would talk to them almost every day. She says that she is too busy this term, taking 16 credits with one class being a class for her major.

Grace stated that she is very shy. With the exception of her classmates and teachers, she mostly interacts with her friends, most of whom are from her native country. She expressed in her interview that even though she will speak English in class, she will use class breaks to talk to her friends in her L1. Karen reports that she has about six American friends, although she scarcely speaks with them. Although she prefers to speak in her native language, Grace is courteous when her American friends are around, much like Will and Jack, speaking in English when they are spending time with her and her native $L 1$ friends.

Grace studies with her friends occasionally. She works best when she is working alone in silence. On the rare days that she does study with her friends, she works entirely with her native friends. During the times when she does study with them, they are usually working on their speaking and listening homework. While they are not practicing they speak their L1 entirely to understand the English they are learning or practicing.

Grace participates in a moderate amount of extracurricular activities, which is shown in table 9 . She attends field trips frequently, going on two trips to Mt. Hood, two trips to the mall, one trip to Seattle, one trip to Multnomah Falls, and a trip to the Tulip Festival. She has also attended a large amount of Portland Trail Blazers' games, going to five during the season. Although she has not attended any of the end-of-the-term parties in the IEP, she has attended all of the welcome parties for the students. She expressed during our interview that she speaks almost entirely in her L1 during these events except when she absolutely has to speak to someone outside of her L1. Lastly, she has only participated in Coffee Hour and the Conversation Partner Program once each, both of which happened in winter term and spring term respectively. 
Table 9: Grace's Participation in Activities.

\begin{tabular}{|l|l|}
\hline \multicolumn{1}{|c|}{ Activities } & \multicolumn{1}{|c|}{ Times Participated } \\
\hline $\begin{array}{l}\text { Conversation Partner } \\
\text { Program }\end{array}$ & 1 drop-in session \\
\hline International Coffee Hour & 1 \\
\hline Field Trips & $\sim 12$ \\
\hline Parties & $\sim 3$ \\
\hline
\end{tabular}

Grace has not come close to failing a class during her time in the IEP. As opposed to the other participants, she does believe she is a good student. However, she states that she needs to study more and continue to improve. Table 10 shows the grades she has received in her classes thus far.

Table 10: Grace's grades in the IEP and university.

\begin{tabular}{|l|l|l|l|}
\hline \multicolumn{1}{|c|}{ Class } & Fall '13 & Winter '14 & Spring '14 \\
\hline Grammar/Writing Level 1 & P & & \\
\hline Reading Level 1 & P & & \\
\hline Speaking/Listening Level 1 & P & & \\
\hline Grammar/Writing Level 2 & & P & \\
\hline Reading Level 2 & & P & \\
\hline Speaking/Listening Level 2 & & P & \\
\hline Guided Research Writing & & & A \\
\hline Advanced English Grammar & & & A- \\
\hline Academic Reading Nonnative Speaker & & A \\
\hline Understanding Academic Lectures & & P & B+ \\
\hline Major Classwork (1 credit) & & & A \\
\hline Skills Enhancement Course* & & & \\
\hline
\end{tabular}

*Different class for each term

During our interview, while asking Grace if she thought she was a good student, she also expressed that she knows she needs to participate in the activities the IEP has to offer. Although Grace attends activities and usually uses her L1, people still speak to her in English. Being very shy, she does not initiate conversation in English. Grace stated that she and her native friends try 
to speak in English, but they almost immediately revert back to their L1. On this she says, "It's natural, but we try." Despite not using the target language to her full advantage at these events, she still sees the activities as a good way to practice.

\section{DISCUSSION}

In this section, I address the findings from my interviews in regards to how they might show a possible relationship between ESL student success and co-curricular activities. Several different themes emerged from the interviews as described in the narratives. These themes provide insight into my original guiding research question as stated in my literature review: What is the relationship between ESL student success and co-curricular activities in an intensive English language program (IEP)?

From my findings in the interviews, Karen, Jack, Will and Grace had good experiences taking part in the IEP's activities. Each interviewee felt like the activities were beneficial, no matter what their level of participation in activities was or the capacity in which they participated. Each participant, with the exception of Grace, expressed their favoritism towards one activity more than the others. For Karen, it was the International Coffee Hour. For Will and Jack, it was the Conversation Partner Program and the variety of field trips respectively.

\section{Conversation Partner Program}

Karen stated that she valued the International Coffee Hour because she had the opportunity to meet people from a variety of other cultures. However, what I saw emerge from our interview is a possible relationship between her grades and the Conversation Partner Program. Karen became more involved though during the winter 2014 term, when she started the Conversation Partner Program. Prior to her start in the Conversation Partner Program, she failed her grammar/writing class and nearly failed her other classes during the fall. As described in her narrative, Karen stated that she hardly participated in activities, but she started to become determined to speak English. The Conversation Partner Program, as it is structured, forces students to interact in the target language. Therefore, Karen had no choice but to use English. She also believes her participation helped her in achieving better English skills and that after she started the Conversation Partner Program, she was able to pass her classes, which remained consistent.

Will claimed that the Conversation Partner Program was the best activity in the IEP, but he participated in all of the activities consistently with the exception of International Coffee Hour. He also had the highest grades of all the students in this study. I can see a similar relationship in his case that I do with Karen's- a relationship between the Conversation Partner Program and student outcomes. It is interesting that Will was placed in both the level 1 speaking/listening and grammar/writing classes during his first term, the fall 2013 term. During the spring 2014 term, after two terms in the program, he skipped over the level 3 grammar class and over levels 3 and 4 of the speaking/listening classes. Furthermore, Will received an A at the completion of his level 5 speaking/listening class.

\section{Personal Struggle and Loss of Motivation}

Jack is a very active participant in the IEP's activities. He stated that he values the field trips the most out of all of the activities in the IEP, expressing during our interview that he likes to travel to different places locally and nationally. It is hard to assess if Jack's grades are linked to his participation in the IEP's activities because of his personal trouble during the winter 2014 term. He stated during our interview that the distractions of this trouble caused him to fail his level 4 reading class ( $F)$ and receive an average grade in his level 4 speaking/listening class (C). With the 
exception of the one field trip he missed, Jack's participation in activities did not waver during the winter 2014 term.

His family trouble settled by the start of the spring 2014 term. After failing his level 4 reading class in the winter, he retook it again in the spring and received a high grade $\left(A^{-}\right)$. However, during the same term, he received a D in his grammar class-- a class that he said he hated. This grade was attributed to the loss of motivation he experienced after passing the TOEFL exam the same term. Because he passed the exam, he no longer needed to pass the class. Because of these additional factors, his family trouble and his loss of motivation, I cannot see if there is a positive link between co-curricular participation and ESL student success.

\section{Opportunities to Practice}

The IEP activities have operated as opportunities to practice where the student is forced to speak in the target language. Practicing, as stated by Oxford (1990), is a form of cognitive learning strategies. Second language researchers and teachers would agree that being in a country where the target language is spoken is the best way to find opportunities to practice (Oxford, 1990). To me, it seems that students who do not actively seek opportunities to practice have taken away a chance for growth in not only language acquisition, but also in student development. I can see this firstly in the contrast between Grace and the other students.

Grace was not as active as the other participants in my study. The way she participates in the activities also differs from the way that the other students participate. Although all of the students, including Grace, see the activities as a way to practice the target language, Grace is the only one who does not speak English during the field trips or at the NBA games. Additionally, she does not often participate in International Coffee Hour or in the Conversation Partner Program. Despite this, Grace is still makes high grades. Although she received two high grades in her grammar class (A-) and speaking/listening $(B+)$, they are lower than her reading and writing grades, both of which she received A's in. The activities in the IEP are not geared towards improving reading and writing skills because they aim for interaction. Grammar, speaking, and listening are skills that would be improved directly as a result of involvement.

\section{Confidence}

There is very little evidence in the data of students gaining confidence; however, there might be evidence in the cases of Karen and Grace. Karen was discouraged from using English when she first started in the program, as stated in her narrative. However, after she failed her grammar class the first term, she reported that she was determined to put herself in more situations with speaking the target language. She also stated during her interview that she taught she was a good student now. I believe that her participation in the activities have helped her find the confidence to be able to pass her classes. By immersing herself in the target language, she was able to improve her English abilities. Furthermore, by immersing herself in the activities and having a better grasp on English, she was able to improve her confidence and find better learning strategies that worked for her, such as her "English-only" rule.

Although I did not put this in my narrative, my interview with Grace was very different from my interviews with the other students. All of the other students were willing to give as much information as possible, but Grace's answers were very brief and vague. This may be reflective of her uncomfortable feelings towards speaking in English during the IEP activities and her selfconfidence (Astin, 1984; Klesse \& D'Onofrio, 2000; Oxford, 1990). All of the other students who participated very actively were speaking almost non-stop, giving large answers to each of the questions I asked. 


\section{CONCLUSION}

This small, preliminary examination between co-curricular activities and ESL student success has revealed differences among a small group of English language learners. Based on the cases of two of my participants (Karen and Will), active participation in activities has supported the claim that students will be more successful if they participate in the social and academic aspects of the collegiate experience. Another case (Jack) has shown that despite active participation in IEP activities, personal struggles, family trouble, and a loss of motivation can still lead to class failure. One case (Grace) has shown that active participation in IEP activities is not needed to achieve high grades, although there may be room for improvement in confidence, speaking ability and grades if the student does choose to participate.

This study has several implications for researchers, teachers, and program administrators. Researchers are not drawing from all the areas of research outside of TESOL that they can. Astin's theory of involvement should have a voice in the area of TESOL and should be a part of relevant research. Furthermore, Xiao and Luo (2009) was the only research-to my knowledge- that explored the relationship between ESL student success and student involvement with a special interest in co-curricular activities. It is for this reason that more qualitative and quantitative research should be conducted to strengthen the clarity of this relationship.

Teachers should promote extracurricular and co-curricular activities in their classroom. I have illustrated that students see these activities as opportunities for practice. Teachers should be aware of the resources that are available on campus and allow students to make an autonomous decision to participate in such activities. Program administrators should continue to fund these activities for their students. Students make decisions about which schools to attend because of location, academics, programs, or educational philosophies. Having a strong catalogue of extra- and cocurricular activities may sway a student's decision to attend a university, and as people who work in academia, it is important for us to empower students and give them agency.

\section{ACKNOWLEDGEMENTS}

I am very grateful for the mentorship of Dr. Kimberley Brown throughout this academic endeavor. Her suggestion that I apply for the Ronald E. McNair Scholars Program changed my life forever. Her guidance and support warms my heart greatly. I would also like to thank Dr. Wayne Gregory for agreeing to review my project. His assistance has been very helpful in this process.

I would like to give further appreciation to my McNair Family, the cohort of 2014. The bonds that I have created with my peers are unbreakable. I cherish every moment we spent together. I would like to give a very special thank you to Ailene Farkac and Shannon Crossley for their friendship and unwavering support since day one.

I would also like to thank the McNair coordinators, Dr. Jolina Kwong Caputo and Dr. Toeutu Faaleava. This would not be possible without you. 


\section{References}

Astin, A. W. (1975). Preventing students from dropping out. San Francisco: Jossey-Bass.

Astin, A. W. (1984). Student involvement: A developmental theory for higher education. Journal of College Student Personnel, 25, 297-308.

Astin, A.W. (1996). Involvement in learning revisited: Lessons we have learned. Journal of College Student Development, 37(2), 123-134.

Astin, A. W. (1999). Student involvement: A developmental theory for higher education. Journal of College Student Development, 40, 518-529.

Bergen-Cico, D., \& Viscomi, V. (2013). Exploring the association between campus co-curricular involvement and academic achievement. Journal of college student retention: Research, theory \& practice, 14(3), 329-343. http://dx.doi.org/10.2190/CS.14.3.c

Brandl, K. (2007) Communicative Language Teaching in Action: Putting Principles to Work. London: Pearson.

Canale, M. (1983). From communicative competence to communicative language pedagogy. In Richards, J. C., \& Schmidt, R. W. (Eds.), Language and Communication, 2-27. London: Longman.

Canale, M.; Swain, M. (1980). Theoretical bases of communicative approaches to second language teaching and testing. Applied Linguistics (1): 1-47.

http://dx.doi.org/10.1093/applin/I.1.1

Hymes, D. H. (1972). On Communicative Competence. In Pride, J. B., \& Holmes, J. (Eds.), Sociolinguistics, 269-293. Baltimore, USA: Penguin Education, Penguin Books Ltd.

Klesse, E.J., \& D'Onofrio, J.A. (2000, October). The value of cocurricular activities. Principal Leadership. Retrieved from https://www.nassp.org/portals/0/content/48943.pdf.

Kuh, G.D., Schuh, J.H., Whitt, E.J., \& Associates (1991). Involving colleges: Successful approaches to fostering student learning and personal development outside the classroom. San Francisco: Jossey-Bass.

Oxford, R. (1990). Language learning strategies: What every teacher should know. New York, USA: Newbury House.

Savignon, S. J. (1997). Communicative competence: Theory and practice. (2nd ed.). New York: McGraw Hill.

VanPatten. B, \& Williams, J. (Eds.). (2006). Theories in second language acquisition: An introduction. London, England: Routledge.

Xiao, L., \& Luo, M. (2009). English co-curricular activities: A gateway to developing autonomous learners. CamTESOL Selected Papers, 5, 239-251. 
Role of metabolic shifts in protection from mutation damage: Characterizing mitochondrial membrane potential in C. elegans gas-1 mutants

by

\author{
Lauren S. Muñoz-Tremblay
}

Faculty Mentor

Dr. Suzanne Estes

Citation: Muñoz-Tremblay, Lauren S. "Role of metabolic shifts in protection from mutation damage: Characterizing mitochondrial membrane potential in $C$.

elegans gas-1 mutants". Portland State University McNair Scholars Online Journal, Vol. 9, 2015. 


\begin{abstract}
Many terminal human diseases are caused by mutations affecting mitochondrial functioning. Mitochondria are essential organelles responsible for producing cellular energy, adenosine triphosphate (ATP) via oxidative phosphorylation (OXPHOS) at mitochondrial electron transport chains (ETC). Proper ETC functioning relies on maintenance of the electrochemical gradient essential for energy production, known as mitochondrial membrane potential $(\Delta \boldsymbol{\Psi} M)$. The inner mitochondrial membrane is the site of the ETC and is most closely in contact with the enzymatic processes occurring within the mitochondrial matrix. Mutations affecting protein components of the ETC are especially troublesome for organelle health. ETC mutants commonly express altered $\Delta \psi M$, as well as increased production of damaging reactive oxygen species (ROS), which are hypothesized to cause genomic damage and lasting mutation. The nematode $C$. elegans is a practical model organism for investigating the phenotypic and genomic consequences of ETC mutations. Despite expressing higher levels of damaging ROS, the ETC protein complex 1 mutant, gas-1, expresses heritable mtDNA and nDNA mutation rates identical to those of wild type animals. I am using a mitochondria-targeted dye and fluorescence microscopy to quantify and compare $\Delta \psi M$ levels of the gas-1 mutant and wild type animals. This work will provide a novel phenotypic characterization of this mutant and indicate whether decreased metabolic activity (e.g., reduced reliance on OXPHOS) is occurring in gas-1, and perhaps conferring protection from genomic degradation. Based on gas-1's characteristically low ATP production and high ROS production, I expect that $\triangle \psi \mathrm{M}$ will be higher in gas-1 as compared to wild type levels.
\end{abstract}




\section{Introduction}

Mitochondria are arguably the most important organelle to cellular health and performance because they are the site of bioenergy metabolism for the entire cell. Glucose is digested and sent to the Citric Acid Cycle (TCA) located in the mitochondrial cytoplasm in the form of pyruvate, which is then metabolized to provide electrons in the form of $\mathrm{NADH}$ and $\mathrm{FADH}_{2}$ for use in oxidative phosphorylation (OXPHOS) occurring at the mitochondrial electron transport chain (ETC). The ETC is comprised of a series of proteins, organized into supercomplexes, located along the inner mitochondrial membrane. The movement of electrons through the complexes of the ETC produces more cellular energy in the form of ATP than glycolysis and the tricarboxylic acid cycle (TCA) cycle combined, and is powered by the constant movement of ions across the inner membrane, known as an electrochemical gradient, or the inner mitochondrial membrane potential $(\Delta \psi M)$.

Mutations in both nuclear DNA (nDNA) and mitochondrial DNA (mtDNA) can be responsible for coded dysfunction in a mitochondrion. Mutations affecting the ETC will consequently inhibit the production of ATP via OXPHOS and possibly other important regulatory functions of mitochondria. In addition to its central role in ETC and cellular function, maintenance of $\Delta \psi M$ is crucial for the process of mitochondrial fusion, and excessive fragmentation (fission) of mitochondria results when $\Delta \Psi \mathrm{M}$ is disrupted due to overwhelming proton translocator activity (Legros, 2002). Cycles of mitochondrial fission and fusion are crucial to overall cell health; however, only mitochondrial fusion is dependent upon $\triangle \Psi M$ (Legros, 2002). Because mitochondrial function is crucial for energy metabolism, dysfunctions within these organelles can lead to a broad range of diseases in animals, including Parkinson's disease in humans (Celardo, Martins, and Gandhi, 2014).

Complex 1 of the ETC is specifically responsible for the oxidation of NADH to lone electrons and protons and creating the initial proton gradient along the inner mitochondrial membrane, which initiates energy production through OXPHOS. This movement of ions is the main source of reactive oxygen species (ROS) due to electron leakage onto molecular oxygen, which is ever present due to the nature of this process (Hicks, Denver, and Estes, 2013). Although some ROS are critically important for molecular signaling, at high levels they are damaging to proteins, can cause morphological changes in mitochondria, disrupt $\triangle \Psi M$, delay organismal development, and cause oxidative damage to DNA and lasting mutation (Shibuya and Tsujimoto, 2012). The idea that ROSinduced oxidative damage is an important source of somatic (non-gamete) or heritable (germline) mutation in nDNA or mtDNA genomes is controversial (Griffiths et al., 2000).

Altered metabolic processes were first observed in colorectal cancer cells (Warburg et al., 1956). The Warburg Effect is a phenomenon characterized by a shift in metabolism from primary use of OXPHOS to a less oxidatively stressful (i.e., lower ROS producing) but much less energetically efficient mixture of aerobic glycolysis and OXPHOS, which benefits rapidly proliferating cells (1956; Lunt and VanderHeiden, 2011). Ericson et al. (2012) measured the frequency of random de novo single base substitutions in the mtDNA of human colorectal cancer cells and discovered that tumor tissue had fewer C:G to T:A transition mutations (known to be associated with oxidative damage) compared to healthy colorectal tissue cells. Ericson et al. (2012) also showed that this decrease in mutation frequency was coupled with a metabolic shift from OXPHOS to anaerobic glycolysis, which was not witnessed in healthy colorectal cells. These findings suggest that the stability of the mitochondrial genome is increased in cancer compared to healthy cells, as a result of a decrease in ROS related mtDNA damage. Inhibited or suppressed energy production has also been observed in a wide variety of other diseases, including diabetes and neurodegenerative disorders (DeBerardinis, 2012). However, whether and to what extent altered or depressed metabolism can protect organisms from heritable (germline) mutations has not been studied.

C. elegans nematodes are becoming an increasingly important model system for studying mitochondrial dysfunction and its relationship with energy metabolism and mutation. These 
microscopic animals are easy to maintain, transparent, non-parasitic, and can be used for studying the effects of mutation on individuals and populations with relative ease. Among several ETC mutant alleles available for $C$. elegans, gas-1 (fc21) is particularly well-studied. gas-1 is a nuclear gene and gas-1 ( $f(21)$ is a single base pair substitution that creates a hypomorphic allele in a protein component of ETC complex 1

(http://www.wormbase.org/species/c_elegans/gene/WBGene00001520?query=gas-1\#0-9e-3). gas-1 expresses many altered physiological phenotypes such as increased dependence on ETC complex II to maintain metabolic homeostasis, decreased growth rate, decreased fecundity, a characteristic hypersensitivity to volatile anesthetics, increased levels of ROS, and decreased OXPHOS abilities as compared to that of wild type (Kayser et at., 2001). Despite the fact that gas1 mutants exhibit elevated levels of damaging ROS, previous studies performed by the D. R. Denver lab (Oregon State Univ.) have concluded that both mtDNA and nDNA mutation rates in gas1 are identical to those expressed by wild type animals (Estes pers. comm.). This result may indicate that ROS do not affect heritable mutation rates as previously thought. Based on these and previous findings, we believe that gas- 1 is experiencing a shift in metabolism synonymous with the Warburg Effect, and as a result, is gaining genomic protection from the mutagenic effects of high levels of ROS by reducing its dependence on energy production via the OXPHOS pathway (c.f., Ericson et al., 2012).

Previous phenotyping of gas-1 has included various life-history and physiological traits (Kayser et al., 2001; Cairo et al., 1992; Estes et al., unpubl.), and studies of gene expression (Falk et al. 2008); however, $\Delta \Psi M$ has not yet been characterized. Further investigation of gas-1 is necessary to understand the effects of mutation on the ETC metabolic process, as well as the possibility of genomic preservation by means of altered metabolic pathways. By quantifying and comparing inner $\triangle \psi \mathrm{M}$ of the mutant gas- 1 to that of wild type animals, it will be possible to gain an understanding of the effects of the gas- 1 mutation on energy production in C. elegans. Because $\Delta \psi M$ drives production of ATP via OXPHOS, these data allow us to detect any change in reliance of gas-1 on this pathway and whether a shift in metabolism may be providing genomic protection for the gas-1 mutant.

\section{Materials \& Methods}

\section{Nematode culture conditions.}

The $C$. elegans N2 strain and the nuclear mutant, gas-1(fc21), were obtained from the Caenorhabditis Genetics Center (University of Minnesota). Prior to experimentation, the D. R. Denver lab (Oregon State University) generated a completely isogenic gas-1 mutant strain via 10 generations of backcrossing to the N2 strain during which the gas-1(fc21) allele was tracked by PCR and Sanger DNA sequencing. Nematodes were thawed from a $-80^{\circ} \mathrm{C} \pm 2^{\circ} \mathrm{C}$ freeze and then kept on $60 \mathrm{~mm}$ Petri plates containing $15 \mathrm{~mL}$ of NGM-Lite agar that had been treated with $20 \mu \mathrm{g} / \mathrm{mL}$ streptomycin and seeded with OP50-1 Escherichia coli as a food source. Worms were regularly transferred to new plates with the use of a sterilized platinum scalpel to maintain small population sizes, avoid starvation, and decrease risk of bacterial contamination. Strains were stored in a dark, $20^{\circ} \mathrm{C}$ incubator. Populations no older than 30 days were used in data collection.

\section{Fluorescence microscopy.}

All methods were adapted from Hicks et al. (2012). When a sufficient number of worms from both strains had reached adulthood, their eggs were harvested to ensure age-synchronicity during future data collection. Age-synchronization was achieved by repeatedly rinsing samples with M9 buffer solution, dissolving adult worms with a 2:1 NaOH:bleach solution, and frequent centrifugation to promote sedimentation of egg pellets (Hicks et al., 2012). 
After the harvested eggs had matured on fresh plates for 24-58 hours, they were allowed to feed on fluorescently dyed $E$. coli for 24 hours (Hicks et al., 2012). A solution of $5 \mu \mathrm{L}$ of Chloromethyl-XRosamine (CMXROS) diluted with $495 \mu \mathrm{L}$ of M9 buffer solution was used per plate. CMXROS is a lipophillic, cationic, fluorescent dye that selectively binds to negatively charged components within the inner mitochondrial membranes of the worms (Pendergrass, Wolf, and Poot, 2004). The worms were then rinsed in M9 buffer solution and allowed to feed on un-dyed $E$. coli for 1 hour to pass any residual dyed $E$. coli from their intestinal tracts. Immediately prior to imaging, all worms were treated with a $20 \mathrm{mM}$ solution of paralytic levamisole. The pharyngeal bulb of each worm was imaged at a total magnification of $25 X$, with the use of a fluorescence stereoscopic dissecting microscope (Leica MSV269). This neuromuscular organ was chosen to quantify $\Delta \psi M$ because of the large amount of localized mitochondria typically found within the boundaries of the bulb (Hicks, et al. 2012). It is also a site that contains minimal amounts of auto-fluorescent fat deposits, which decreases the likelihood of fluorescent interference during imaging.

Image processing and data analysis.

After images were collected, each bulb was manually encapsulated using ImageJ software (NIH). They were then analyzed by measuring mean and maximum fluorescence values and total area of each bulb in ImageJ. Statistical comparison of the two strains was achieved using a non-parametric Wilcoxon chi-square approximation (first data set) or a Student's t-test (second data set) performed in JMP 9.0 (SAS). During image analysis, it became apparent that half of the nematodes comprising the first data set had not matured to the young adult stage prior to imaging. Because of this, a second set of data was collected and analyzed after the new sample had been verified to be young adult nematodes.

\section{Results}

Two sets of data from a total of three imaging sessions that took place in July and August were analyzed separately. Data were grouped in this fashion due to among-assay differences in nematode developmental stage (above). The first set of data (Figure 1) indicated that gas-1 exhibited significantly lower levels of $\Delta \psi \mathrm{M}$ than the wildtype $\mathrm{N} 2$ strain (Wilcoxon $\mathrm{X}^{2}=14.3, \mathrm{df}=1$, $\mathrm{N}=133, \mathrm{p}=0.0002$ ). Analysis of mean pixel intensity showed an identical pattern (data not shown). The second set of data (Figure 2.1) showed that gas-1 trended toward higher $\Delta \psi M$ levels than the wildtype $\mathrm{N} 2$ strain ( $\mathrm{t}=-1.44, \mathrm{df}=1, \mathrm{~N}=77, \mathrm{p}=0.1547$ ), although the difference was not statistically significant. It was also observed that the wildtype strain had significantly larger pharyngeal bulbs than those of gas- $1(t=6.06, d f=1, N=77, p<0.0001)$ in the second data set (Figure 2.2). 


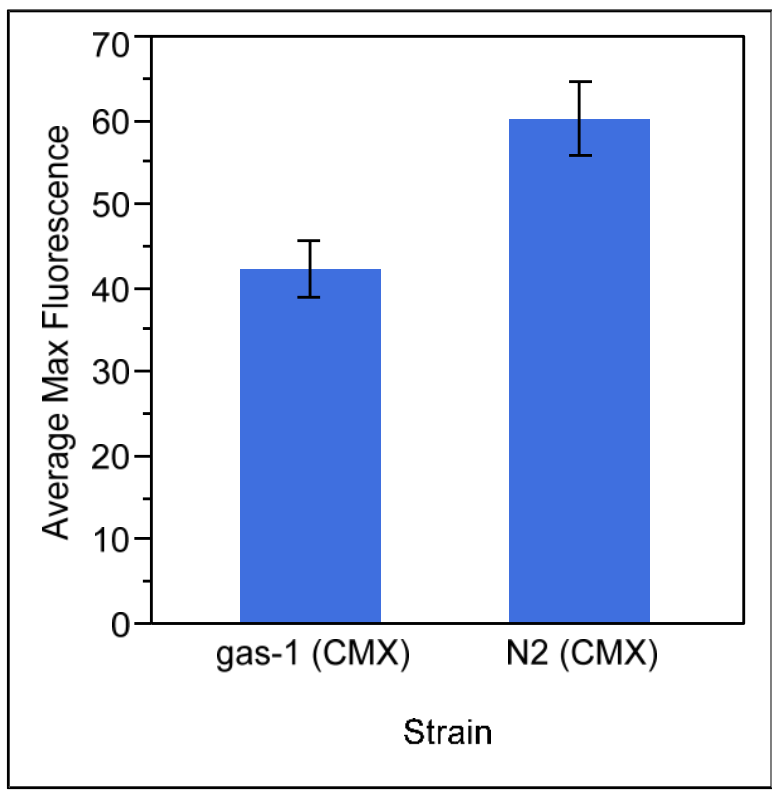

Figure 1: gas-1 strain exhibits lower levels of average maximum fluorescence within pharyngeal bulbs stained with MitoTracker CMXROS. Maximum fluorescence is measured in pixel intensity, $\mathrm{Y}$ axis. Error bars indicate one SEM $(S D / \sqrt{ } N)$.

\section{Conclusion:}

The first set of data $(\mathrm{N}=133)$ indicated that gas -1 exhibited lower $\Delta \psi M$ than that of wildtype N2 (Figure 1), although upon closer inspection it was determined that the animals were not imaged at the appropriate young adult stage necessary for accurate data collection. As $C$. elegans reaches maturity, it experiences a marked increase in the numbers of mitochondria accompanied by a shift in primary metabolic reliance from the TCA cycle/glyoxylate cycle to OXPHOS (Intermediary metabolism: Metabolic patterns during development and aging: 7-9, Wormbook, 2009); therefore, a lack of metabolic maturity could underlie the lower $\Delta \psi M$ of gas-1 compared to the wildtype N2 strain. Results from the second set of data ( $N$ $=77$ ), which used a verified young adult population, suggested that the gas-1 population expressed higher levels of $\Delta \psi M$ than that of the wildtype population (Figure 2.1), although the difference was not statistically significant. This observation could indicate that the gas- 1 mutation affecting ETC Complex 1 prohibits dissipation of $\Delta \psi M$ down the ETC, resulting in a highly polarized electrochemical gradient, which could also be contributing to gas-1's characteristically high ROS levels and abnormally low level of ATP production (Brand, 2000). The second set of data also revealed that gas- 1 had significantly smaller mean pharyngeal bulb areas than those of N2 (Figure 2.2). This large difference in bulb size between strains could be explained by the less efficient and less healthy metabolism of gas-1. Similarly, it is well-understood that the movement of the pharynx, or pharyngeal pumping, is recognized as a proxy for metabolic rate in $C$. elegans (Collins, 2008).

Future work will conduct additional trials using a larger sample size will be used during data collection, and use confocal fluorescence microscopy, which will allow imaging of separate focal planes at higher magnification and increased resolution. This experiment will also be repeated using ten mutationaccumulation (MA) lines generated from either gas-1 or N2 (in addition to the gas-1 and N2 progenitor strains) to further explore the possibility of a shift in metabolism from OXPHOS to glycolysis among lines that have accumulate mutations under genetic drift against either the gas-1 mutant or wildtype genetic background. Based on my preliminary findings, I would expect that gas$1 \mathrm{MA}$ lines would show further increased $\Delta \psi M$

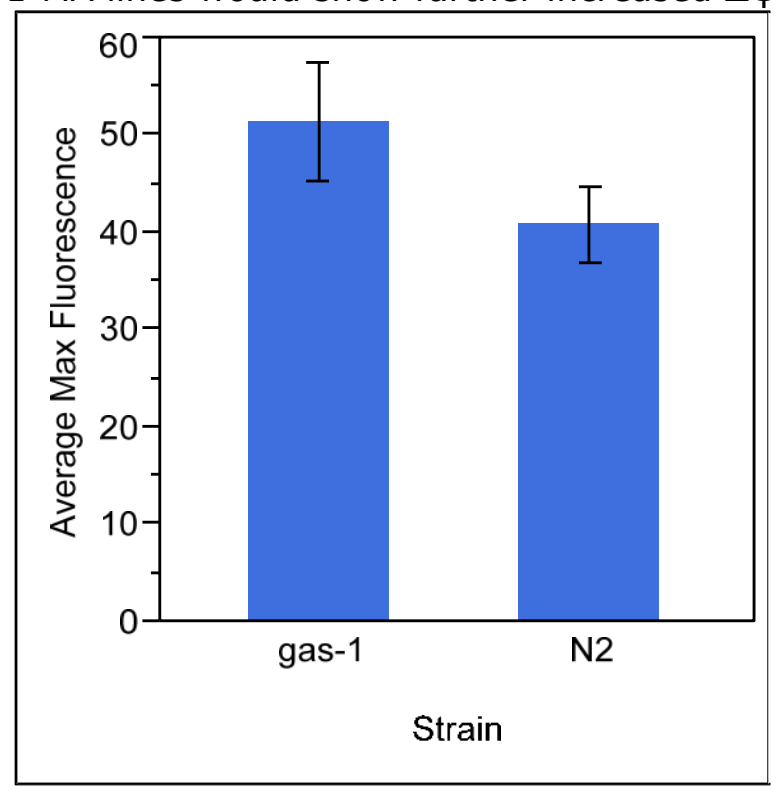


levels and would show greater variability in $\Delta \psi M$ levels from gas-1 progenitor than N2 MA lines would show compared to N2 progenitor.

In contrast, I would expect N2 MA lines to

Figure 2.1: gas-1 strain exhibits higher average maximum fluorescence within pharyngeal bulbs stained with MitoTracker CMXROS than that of

wildtype. Maximum fluorescence is measured in

units of pixel intensity, $\mathrm{Y}$-axis. Error bars indicate one $\operatorname{SEM}(\mathrm{SD} / \sqrt{ } \mathrm{N})$.

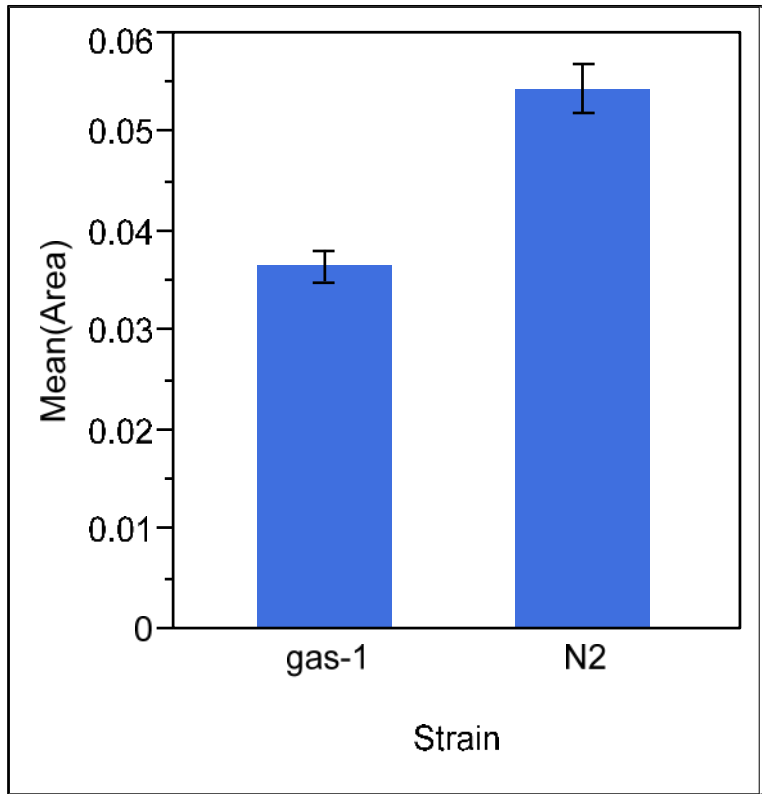

Figure 2.2: gas-1 strain exhibits smaller pharyngeal bulb area than that of wildtype N2 when CMXROS stained organs are manually encapsulated and measured with ImageJ data analysis software. Pharynx area is measured in pixels ${ }^{2}, \mathrm{Y}$-axis. Error bars indicate one SEM $(\mathrm{SD} / \sqrt{ } \mathrm{N})$. have similar or lower levels of $\Delta \psi M$ compared to N2 progenitor. 


\section{Bibliography}

1. Baer, Charles F. et al. "Comparative Evolutionary Genetics of Spontaneous Mutations Affecting Fitness in Rhabditid Nematodes." Proceedings of the National Academy of Sciences of the United States of America 102.16 (2005): 5785-5790. www.pnas.org. Web. 31 Mar. 2014.

2. "Barrick Lab: Procedure Bacterial Mutation Accumulation." N.p., n.d. Web. 31 Mar. 2014.

3. Bess, Amanda S. et al. "Mitochondrial Dynamics and Autophagy Aid in Removal of Persistent Mitochondrial DNA Damage in Caenorhabditis Elegans." Nucleic Acids Research 40.16 (2012): 7916-7931. http://www.dx.doi.org/10.1093/nar/gks532

4. Braeckman, Bart P. "Intermediary Metabolism." WormBook (2009): 1-24. CrossRef. Web. 10 Aug. 2014.

5. Brand, M. D. "Uncoupling to Survive? The Role of Mitochondrial Inefficiency in Ageing." Experimental Gerontology 35.6-7 (2000): 811-820. Print. http://dx.doi.org/10.1016/S0531-5565(00)00135-2

6. Celardo, I, L M Martins, and S Gandhi. "Unravelling Mitochondrial Pathways to Parkinson's Disease." British Journal of Pharmacology 171.8 (2014): 1943-1957. Wiley Online Library. Web. 12 July 2014. http://dx.doi.org/10.1111/bph.12433

7. Chial, H. and Craig, J. "mtDNA and Mitochondrial Diseases." Nature Education 1 (2008):217.

8. DeBerardinis, Ralph J., and Craig B. Thompson. "Cellular Metabolism and Disease: What Do Metabolic Outliers Teach Us?" Cell 148.6 (2012): 1132-1144. www.cell.com. Web. 15 July 2014.

9. Ericson, Nolan G. et al. "Decreased Mitochondrial DNA Mutagenesis in Human Colorectal Cancer." PLoS Genet 8.6 (2012): e1002689. PLoS Journals. Web. 12 July 2014. http://www.dx.doi.org/ 10.1371/journal.pgen.1002689

10. Estes, Suzanne, Patrick C. Phillips, et al. "Mutation Accumulation in Populations of Varying Size: The Distribution of Mutational Effects for Fitness Correlates in Caenorhabditis Elegans." Genetics 166.3 (2004): 1269-1279

http://dx.doi.org/10.1534/genetics.166.3.1269

11. ---. "Mutation Accumulation in Populations of Varying Size: The Distribution of Mutational Effects for Fitness Correlates in Caenorhabditis Elegans." Genetics 166.3 (2004): 1269-1279. http://dx.doi.org/10.1534/genetics.166.3.1269

12. Estes, Suzanne, Anna L. Coleman-Hulbert, et al. "Natural Variation in Life History and Aging Phenotypes Is Associated with Mitochondrial DNA Deletion Frequency in Caenorhabditis Briggsae." BMC Evolutionary Biology 11.1 (2011): 11. www. biomedcentral.com. Web. 15 July 2014.

13. Estes, Suzanne, Patrick C. Phillips, and Dee R. Denver. "Fitness Recovery and Compensatory Evolution in Natural Mutant Lines of C. Elegans." Evolution 65.8 (2011): 2335-2344. http://dx.doi.org/10.1111/j.1558-5646.2011.01276.x

14. MJ, Falk et al. "Metabolic Pathway Profiling of Mitochondrial Respiratory Chain Mutants in C. Elegans." Molecular genetics and metabolism 93.4 (2008): 388-397. http://dx.doi.org/10.1016/j.ymgme.2007.11.007

15. "fc21 (variation) - WormBase: Nematode Information Resource." N.p., n.d. Web. 12 July 2014.

16. Griffiths, Anthony JF et al. "Somatic versus Germinal Mutation." (2000): n. pag. http://www.ncbi.nlm.nih.gov/books/NBK21894/

17. Hicks, Kiley A. et al. "In Vivo Quantification Reveals Extensive Natural Variation in Mitochondrial Form and Function in Caenorhabditis Briggsae." PLOS ONE 7.8 (2012): e43837. PLoS Journals. http://www.dx.doi.org/ 10.1371/journal.pone.0043837 
18. Hicks, Kiley A., Dee R. Denver, and Suzanne Estes. "Natural Variation in Caenorhabditis Briggsae Mitochondrial Form and Function Suggests a Novel Model of Organelle Dynamics." Mitochondrion 13.1 (2013): 44-51.

http://dx.doi.org/10.1016/j.mito.2012.12.006

19. Joyner-Matos, Joanna, Kiley A. Hicks, et al. "Evolution of a Higher Intracellular Oxidizing Environment in Caenorhabditis Elegans under Relaxed Selection." PLOS ONE 8.6 (2013): e65604. PLoS Journals. Web. 31 Mar. 2014.

20. Joyner-Matos, Joanna, Laura C. Bean, et al. "No Evidence of Elevated Germline Mutation Accumulation Under Oxidative Stress in Caenorhabditis Elegans." Genetics 189.4 (2011): 1439-1447. http://dx.doi.org/10.1534/genetics.111.133660

21. Kayser, Ernst-Bernhard, Charles L. Hoppel, et al. "A Mutation in Mitochondrial Complex I Increases Ethanol Sensitivity in Caenorhabditis Elegans." Alcoholism: Clinical and Experimental Research 27.4 (2003): 584-592.

http://dx.doi.org/10.1111/j.1530-0277.2003.tb04394.x

22. Kayser, Ernst-Bernhard, Phil G. Morgan, et al. "Mitochondrial Expression and Function of GAS-1 in Caenorhabditis Elegans." Journal of Biological Chemistry 276.23 (2001): 20551-20558. http://dx.doi.org/10.1074/jbc.M011066200

23. Keightley, Peter D. "Rates and Fitness Consequences of New Mutations in Humans." Genetics 190.2 (2012): 295-304. http://dx.doi.org/10.1534/genetics.111.134668

Kidane, Dawit, and Joann B. Sweasy. "Tipping the Balance in the Powerhouse of the Cell to 'Protect' Colorectal Cancer." PLoS Genet 8.6 (2012): e1002758. PLoS Journals. Web. 12 July 2014.

24. Legros, Frédéric et al. "Mitochondrial Fusion in Human Cells Is Efficient, Requires the Inner Membrane Potential, and Is Mediated by Mitofusins." Molecular Biology of the Cell 13.12 (2002): 4343-4354. http://dx.doi.org/10.1091/mbc.E02-06-0330

25. Lunt, Sophia Y., and Matthew G. Vander Heiden. "Aerobic Glycolysis: Meeting the Metabolic Requirements of Cell Proliferation." Annual Review of Cell and Developmental Biology 27.1 (2011): 441-464. http://dx.doi.org/10.1146/annurev-cellbio-092910-154237

26. "The Measurement and Analysis of Age-Related Changes in Caenorhabditis Elegans WormBook - NCBI Bookshelf." N.p., n.d. Web. 15 Aug. 2014.

27. Mullen, Andrew R. et al. "Reductive Carboxylation Supports Growth in Tumour Cells with Defective Mitochondria." Nature 481.7381 (2012): 385-388. http://www.dx.doi.org/ $10.1038 /$ nature 10642

28. Osada, Naoki, and Hiroshi Akashi. "Mitochondrial-Nuclear Interactions and Accelerated Compensatory Evolution: Evidence from the Primate Cytochrome c Oxidase Complex." Molecular Biology and Evolution 29.1 (2012): 337-346. http://dx.doi.org/10.1093/molbev/msr211

29. Paula, Wilson B. M. de et al. "Female and Male Gamete Mitochondria Are Distinct and Complementary in Transcription, Structure, and Genome Function." Genome Biology and Evolution 5.10 (2013): 1969-1977. http://dx.doi.org/10.1093/gbe/evt147

30. Pendergrass, W., N. Wolf, and M. Poot. "Efficacy of MitoTracker Green ${ }^{\mathrm{TM}}$ and CMXrosamine to Measure Changes in Mitochondrial Membrane Potentials in Living Cells and Tissues." Cytometry Part A 61A.2 (2004): 162-169. http://dx.doi.org/10.1002/cyto.a.20033

31. Prezant, Toni R. et al. "Mitochondrial Ribosomal RNA Mutation Associated with Both Antibiotic-induced and Non-syndromic Deafness." Nature Genetics 4.3 (1993): 289294. http://dx.doi.org/10.1038/ng0793-289

32. Raamsdonk, Jeremy Michael Van et al. "Decreased Energy Metabolism Extends Life Span in Caenorhabditis Elegans Without Reducing Oxidative Damage." Genetics 185.2 (2010): 559-571. http://dx.doi.org/10.1534/genetics.110.115378 
33. Shibuya, Toshiharu, and Yoshihide Tsujimoto. "Deleterious Effects of Mitochondrial ROS Generated by KillerRed Photodynamic Action in Human Cell Lines and C. Elegans." Journal of Photochemistry and Photobiology B: Biology 117 (2012): 1-12. http://dx.doi.org/10.1016/j.jphotobiol.2012.08.005

34. Taylor, Robert W., and Doug M. Turnbull. "Mitochondrial DNA Mutations in Human Disease." Nature Reviews Genetics 6.5 (2005): 389-402. http://dx.doi.org/10.1038/nrg1606

35. Warburg, Otto, and others. "On the Origin of Cancer Cells." Science 123.3191 (1956): 309314. Print. http://dx.doi.org/10.1126/science.123.3191.309

36. Wielgoss, Sébastien et al. "Mutation Rate Dynamics in a Bacterial Population Reflect Tension between Adaptation and Genetic Load." Proceedings of the National Academy of Sciences 110.1 (2013): 222-227.

http://dx.doi.org/10.1073/pnas.1219574110 
Portland State University McNair Research Journal 2015

Characterization of the role that alternative ribonucleotide reductases play in restoring replication in the presence of hydroxyurea in Escherichia coli

\author{
By \\ Michael Sadek
}

Faculty Mentor: Dr. Justin Courcelle

Citation: Sadek, M. Characterization of the role that alternative ribonucleotide reductases play in restoring replication in the presence of hydroxyurea in Escherichia coli. Portland State University McNair Scholars Online Journal, Vol. 9, 2015. 


\begin{abstract}
DNA replication is essential for cells to grow and divide. Ribonucleotide reductase is an essential enzyme that is responsible for the formation of deoxyribonucleotides that are used in DNA synthesis during replication. Hydroxyurea is a chemotherapeutic agent that is thought to work by specifically inhibiting the ribonuceotide reductase to prevent replication. However, recent studies in $E$. coli have shown that following an initial period of inhibition, DNA synthesis then recovers in the presence of hydroxyurea, suggesting that the mode of death and cellular response to hydroxyurea is more complex than originally proposed. The E.coli genome encodes three ribonucleotide reductases that are thought to operate under distinct cellular conditions. Here, we examined whether either of the two alternative riboucleotide reductases may be resistant to hydroxyurea treatment and allow replication to recover in its presence. To test this, mutants lacking either the iron-starvation reductase, NrdEF, or the anaerobic reductase, NrdDG were examined for their ability to recover DNA synthesis in the presence of hydroxyurea. We observed that, both $n r d E F$ and $n r d D G$ mutants recovered replication similar to wild type cultures, suggesting that these enzymes are not responsible for the observed recovery. We discuss these results in relation to their implications for the mechanism by which hydroxyurea operates to inhibit and kill growing cells.
\end{abstract}




\section{Introductions}

Replication is the process by which the cell duplicates its DNA. Cells use deoxyribonucleotide triphosphates to build DNA. Ribonucleotide reductase is the enzyme that is responsible for the reduction of ribonucleotides triphosphates to form deoxyribonucleotides-triphosphates that are precursors of DNA synthesis (1). This enzyme plays a critical role in regulating the rate of DNA synthesis as well as maintaining the fidelity of replication (1). The primary ribonucleotide reductase found in aerobic bacteria and mammals consists of two non-identical subunits, protein $\mathrm{R} 1$ and R2. These proteins need $\mathrm{Mg}^{+2}$ in order to be active (2). The R1 protein contains the redox-active thiols in each of its two active sites. The $\mathrm{R} 2$ subunit contains a binuclear iron center and organic free radical (3).

Escherichia coli contain three ribonucleotide reductases that each function under different growth conditions. The class la enzyme, encoded by $n r d A B$, consists of two subunits. The larger subunit is encoded by $n r d A$ and contains the active site and allosteric binding site. The smaller subunit is encoded by $n r d B$ and contains a dinuclear iron center (4). NrdAB is an iron dependant enzyme and is essential for aerobic growth. The class $1 \mathrm{~b}$ enzyme is encoded by $n r d E F$, utilizes manganese rather than iron. The alternative aerobic deoxyribonucleotide reductase of $E$. coli, $\mathrm{NrdEF}$, is a manganese-dependent enzyme that enables cell replication during periods of iron starvation (5). The E. coli genome has also $n r d D$ and $n r d G$ genes that are essential for strict anaerobic growth (6).

Hydroxyurea is a therapeutic agent extensively used in the clinical treatment of hematological malignancies $(7,8)$, chronic myelogenous leukemia (9), sickle-cell disease (10), carcinomas, and other diseases (7). Hydroxyurea is thought to specifically inhibit ribonucleotide reductase, depleting the pools of deoxyribonucleoside triphosphates, thereby leading to stalled replication forks that prevent cells from progressing through $S$ phase (1). Mechanistically, hydroxyurea diffuses into cells and forms a free radical nitroxide, quenching the tyrosyl free radical at the active site of the M2 protein subunit of ribonucleotide reductase and inactivating the enzyme (11).

Although hydroxyurea has been used to study replication fork arrest for decades, a number of mechanic questions remain about how it affects replication, dNTP pools, and cell viability. In addition to pausing replication, some evidence suggests that hydroxyurea also induces DNA damage (12), which may contribute to its effectiveness in chemotherapies. Treatment with hydroxyurea leads to loss of cell viability and eventual cell lyses (13), an observation that is inconsistent with hydroxyurea simply pausing replication forks (14). The cell lysis correlates with an increase in oxidative free radical formation, suggesting that oxidative damage to DNA and potentially proteins plays a role in the observed lethality. Intriguingly, prolonged hydroxyurea stress activates mazEF and relBE toxin/anti-toxin modules that have been implicated in cell lysis following either oxidative damage or depletion of thymine pools in a phenomenon termed "thymineless" death (15). These observations implicate oxidative or free radical damage as a potential mechanism for hydroxyurea-mediated lethality.

In addition, there are conflicting reports in the literature as to the effect of hydroxyurea on replication and deoxyribonucleotide pools in vivo (1). Some studies found that hydroxyurea arrests DNA replication by a mechanism that preserves basal dNTP pools (16). And a recent 
study from our lab by Neda Savic demonstrated that replication appears to recover in E. coli treated with hydroxyurea after a brief inhibition period (17). The mechanism by which replication recovers under these conditions is not presently understood, however it may be that other ribonucleotide reductases in E.coli are less sensitive to the inhibitory effects of hydroxyurea, or become activated when free radical stress conditions are induced by hydroxyurea treatment.

To further understand the mechanism by which replication is inhibited but then recovers when hydroxyurea is present, I examined how the rate of DNA synthesis is affected by hydroxyurea in ribonucleotide reductase mutants. To accomplish this, I genetically engineered mutants lacking either NrdEF or NrdDG and then tested whether the absence of these reductases affected its ability to recover DNA synthesis in the presence of hydroxyurea. I observed that both mutants recovered replication similar to wild type cultures.

\section{Material and Methods}

Bacterial Strains, and Culture Medium

The SR108 parental strain is a thymine autotrophic (thyA36 deoC2) derivative of W3110 (18). All bacterial strains were propagated in Davis medium (19) supplemented with $0.4 \%$ glucose and $0.2 \%$ CAS amino acids (DGC). DGC growth medium for thymine auxotroph was also supplemented with $10 \mu \mathrm{g} / \mathrm{ml}$ thymine (DGCthy).

Construction of Escherichia coli deletion mutants by $P 1$ transduction Isogenic mutants deleted for either $n r d E F$ or $n r d D$ or $n r d G$ were constructed using phage $\mathrm{P} 1$ to transduce the genes from donor strains CL2581 containing the nrdEF::cat allele (Courcelle Lab Stock), JW4196-3 containing the del(nrdG784::kan) allele (20) and JW4197-1 containing the del(nrdD785::kan) allele into SR108 recipient (21).

The strain donors that had the gene of interest were streaked on agar plates overnight. Then a single colony of each strain was grown in $5 \mathrm{ml}$ Luria Butani (LB) media (19) supplemented with $5 \mathrm{mM} \mathrm{CaCl} 2$ overnight. $100 \mu \mathrm{L}, 10 \mu \mathrm{L}$ and $1 \mu \mathrm{L}$ of $\mathrm{P} 1$ virion lysate was added to three $1 \mathrm{ml}$ aliquots of the overnight culture. The mixtures were then incubated in a $37 \mathrm{C}$ water bath for one hour.

While the infection was taking place, $R$ top-agar was melted and kept at $42 \mathrm{C}$ beside the $\mathrm{LB}$ agar plates. Then at the end of incubation, $4 \mathrm{ml}$ top agar was added to each tube and the mix was poured on LB plate. Plates were then incubated overnight at $37 \mathrm{C}$. The agar, containing the lysate was removed, collected in tubes, and centrifuged for 15 minutes at 14,000 rpm. The supernatant was collected into fresh tubes. $100 \mu \mathrm{l}$ of chloroform was added, and the lysate was centrifuged again for 15 minutes. The supernatant containing the phage was collected and a few drops of chloroform were added to it before it was stored at $4 \mathrm{C}$.

For transduction, the recipient strain, SR108, was cultured and grown in LBthy media supplemented with $5 \mathrm{~mm} \mathrm{CaCl}_{2}$ at $37 \mathrm{C}$ overnight. $100 \mu \mathrm{l}$ of $\mathrm{P} 1$ phage lysate made from the donor strains was added to $100 \mathrm{ul}$ of culture, and incubated for 15 minutes at $30 \mathrm{C}$ to allow infection to occur. At the end of incubation, $40 \mu \mathrm{l} 1 \mathrm{M}$ of sodium citrate was added to each tube. 
The mixture was then spread on LB plates containing the appropriate antibiotic for selection, and plates were incubated overnight at $37 \mathrm{C}$.

\section{Replication Inhibition Assays}

Sample cultures were prepared for the three mutants and the wild type. $0.4 \mathrm{ml}$ of overnight culture was diluted into $40 \mathrm{ml} \mathrm{DGCthy} \mathrm{containing} 0.1 \mathrm{uCi} / \mathrm{ml} 14 \mathrm{C}$-thymine and it was incubated in $37 \mathrm{C}$ water bath for three hours. A label mix was prepared by adding $10 \mu \mathrm{Ci} / \mathrm{ml}$ of $3 \mathrm{H}$ thymidine to $2 \mathrm{ml}$ DGCthy media. $0.5 \mathrm{ml}$ of the labeling mix was added to the PP tubes. 2-0.5 $\mathrm{ml}$ aliquots per treatment were placed into the tubes containing labeling mix. They were vortexed for 2 seconds and returned to $37 \mathrm{C}$ water bath for 2 minutes. Cultures were split into $2-20 \mathrm{ml}$ aliquots. Then $1 \mathrm{ml}$ of $\mathrm{H} 2 \mathrm{O}$ was added to one flask and hydroxyurea to the other one. Aliquots were pulsed and collected in the same way at $-5,0,5,10,20,30,40,50$ and 60 minutes. Cells were then lysed with $5 \%$ cold trichloroacetic acid (TCA, Fisher brand) and the precipitated DNA was collected on glass fiber filters (Millipore). The filters were rinsed twice with ethanol, dried, and then the amount of $3 \mathrm{H}$ and $14 \mathrm{C}$ on each filter was determined using a scintillation counte

\section{Results}

To address how the alternative ribonucleotide reductase affects the recovery of replication in the presence of hydroxyurea, isogenic mutants were constructed containing deletions in $n r d E F, n r d D$ and $n r d G$. To monitor the rate of DNA synthesis and overall DNA accumulation that occurred in the presence of hydroxyurea, the amount of $3 \mathrm{H}$ thymidine incorporated during a 2 min pulse into cultures pre-labeled with 14C-thymine was followed over time. To this end, growing 14C-thymine prelabeled cultures were split and either treated with $100 \mathrm{mM}$ hydroxyurea, or mock-treated. Then, aliquots of the culture were pulse labeled for 2 min at various time points, and the amount of $3 \mathrm{H}$ (rate of synthesis) and 14C (total DNA accumulation) incorporated into the DNA at each time point was determined. Consistent with previous observations from our lab (21); following addition of hydroxyurea in wild type cultures, the rate of replication was inhibited by more than $90 \%$ within 5 minutes of hydroxyurea addition Figure 1. However, the rate of replication then began to recover within 10 minutes of treatment, and had fully recovered to its pretreated rate by the end of the 60 minute time course. The overall accumulation of DNA was found to be less after adding hydroxyurea. I observed that total DNA accumulation was less than untreated cultures by the end of the 60 minute time course.

In mock treated cultures, the rate of DNA continued at a similar rate throughout the time course and DNA continued to accumulate. 

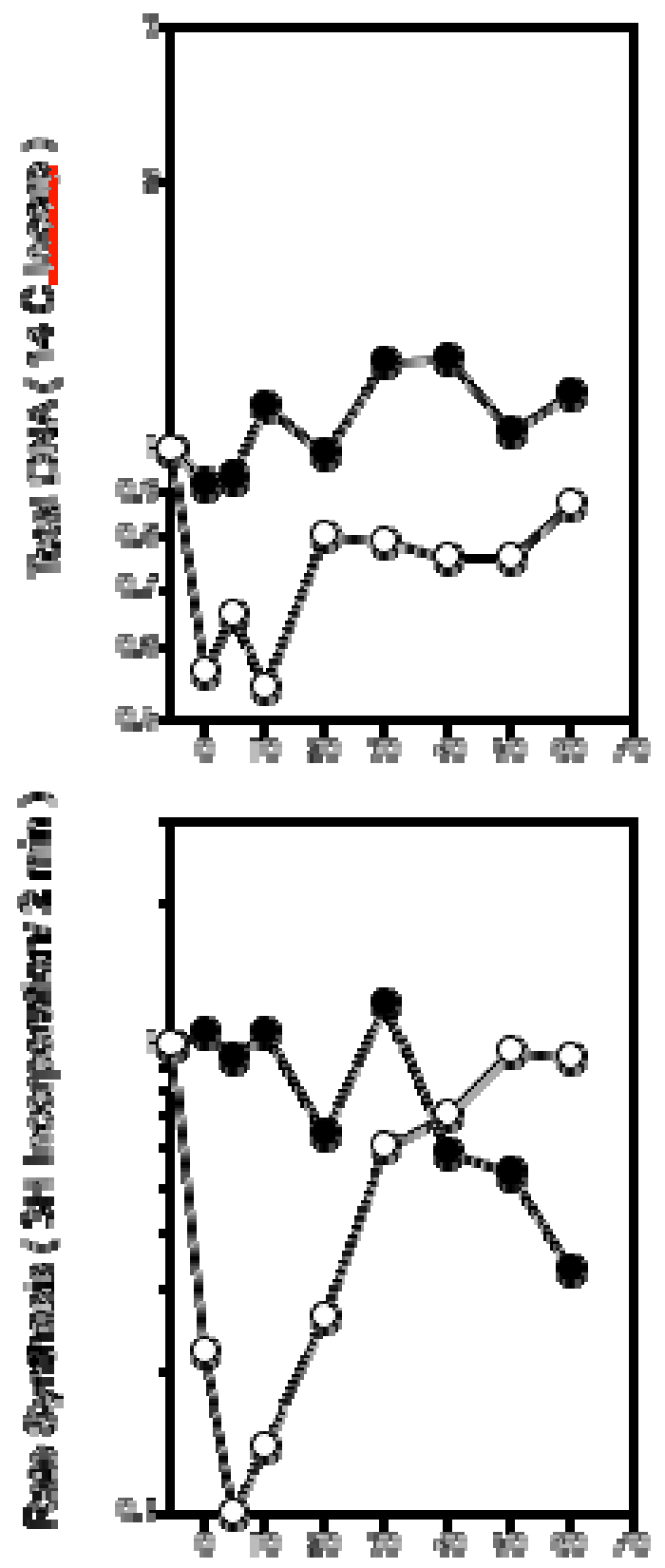

\section{Trma ụininu}

Figure (1): Following an initial period of inhibition, the rate of replication recovers in the presence of hydroxyurea. Cultures grown in media supplemented with 14C-thymine were labeled with a pulse of $3 \mathrm{H}$-thymidine for $2 \mathrm{~min}$ at various time points following the addition of hydroxyurea. The amounts of $3 \mathrm{H}$ and $14 \mathrm{C}$ incorporated into the DNA (relative to pre treatment levels) are plotted over time. (Top) DNA accumulation; black circles, mock treatment; white circles, $100 \mathrm{mM} \mathrm{HU.(Bottom)}$ Rate of synthesis; black circles, mock treatment; white circles, $100 \mathrm{mM} \mathrm{HU}$. The initial amount of $3 \mathrm{H}$ and $14 \mathrm{C}$ at 5 minutes prior to treatment were 13935CPM and 3056.5CPM respectively. 
To examine whether the Mn-dependent, cryptic ribonucleotide reductase, encoded by $n r d E F$, was responsible for the observed recovery of replication; I examined how replication was affected in hydroxyurea-treated cultures of $n r d E F$ mutants. I observed that the inhibition and recovery looked similar to that in wild type cultures. As shown in Figure 2, the rate of replication was inhibited by $90 \%$ within 5 minutes of addition. However, the rate of replication then began to recover, reaching rates similar to those in the mock treated samples by the end of the time course. The overall accumulation of DNA was found to be less in the presence of hydroxyurea. I found that DNA accumulation in the treated sample was inhibited relative to the mock treated culture.

I interpret these results to indicate that $\mathrm{NrdEF}$ is not required for replication to recover in the presence of hydroxyurea. 


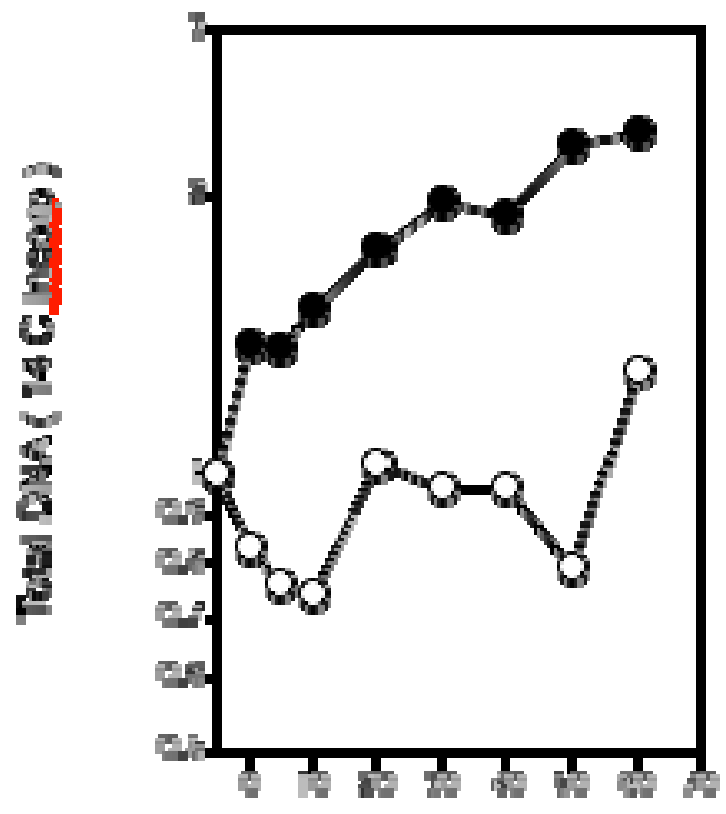

Figure (2): The absence of NrdEF does not prevent replication from recovering in the presence of hydroxyurea. Cultures grown in media supplemented with 14C-thymine were labeled with a pulse of $3 \mathrm{H}$-thymidine for $2 \mathrm{~min}$ at various time points following the addition of hydroxyurea. The amounts of $3 \mathrm{H}$ and $14 \mathrm{C}$ incorporated into the DNA (relative to pre treatment levels) are plotted over time. (Top) DNA accumulation; black circles, mock treatment; white circles, $100 \mathrm{mM} \mathrm{HU}$. (Bottom) Rate of Synthesis; black circles, mock treatment; white circles, $100 \mathrm{mM} \mathrm{HU}$. The initial amount of $3 \mathrm{H}$ and $14 \mathrm{C}$ at 5 minutes prior to treatment were $8800 \mathrm{CPM}$ and $1752.5 C P M$ respectively.

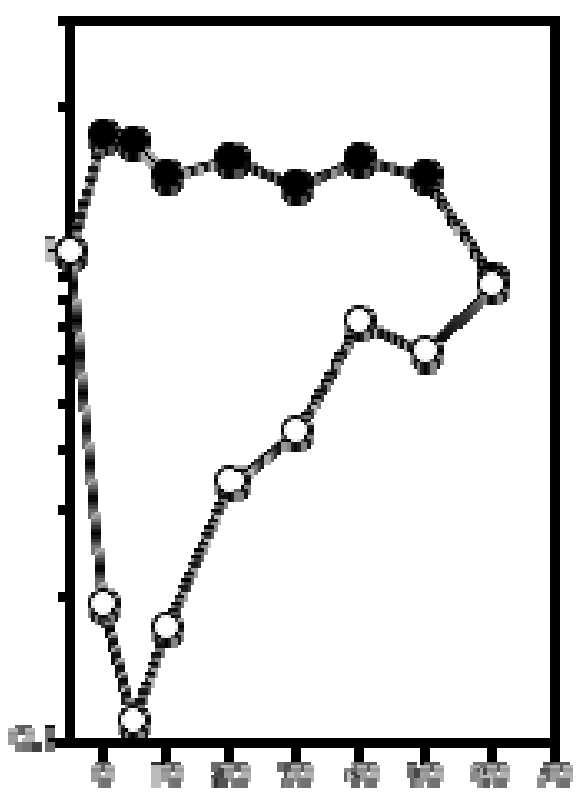

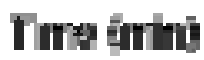


I next examined whether the anaerobic ribonucleotide reductase, encoded by $n r d D$ and $n r d G$, affected the ability of cells to restore replication. When I examined replication in hydroxyureatreated cultures of $n r d D$ mutants, I observed that the inhibition and recovery looked similar to that in treated wild type cultures. As shown in Figure 3A, the rate of replication was inhibited by more than $70 \%$ within 5 minutes of addition. However, the rate of replication then began to recover, reaching a rate similar to that of the mock treated culture by the end of the time course. The overall accumulation of DNA was also inhibited in the hydroxyurea-treated $n r d D$ mutant to an extent similar to that seen in treated wild type culture.

Similarly, when I examined replication in hydroxyurea-treated cultures of $n r d G$ mutants, I observed that the inhibition and recovery looked similar to that in wild type cultures. As shown in Figure 3B, the rate of replication was inhibited by $90 \%$ within 5 minutes of addition. However, similar to wild type cultures, the rate of replication recovered to near pretreatment levels by the end of the 60 minute time course. Also, similar to the other strains examined, the overall accumulation of DNA was partially inhibited by the addition of hydroxyurea.

Taken together, these results indicate that neither that NrdD nor NrdG is required for replication to recover from hydroxyurea. 
A)
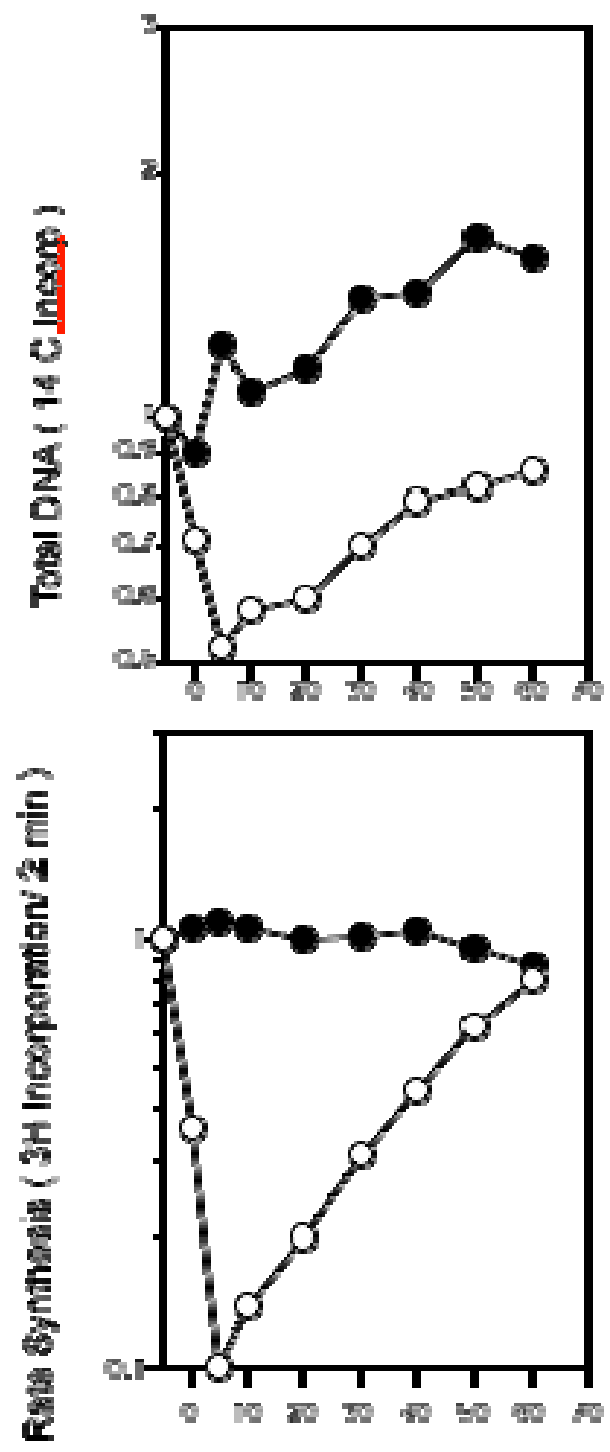

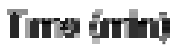
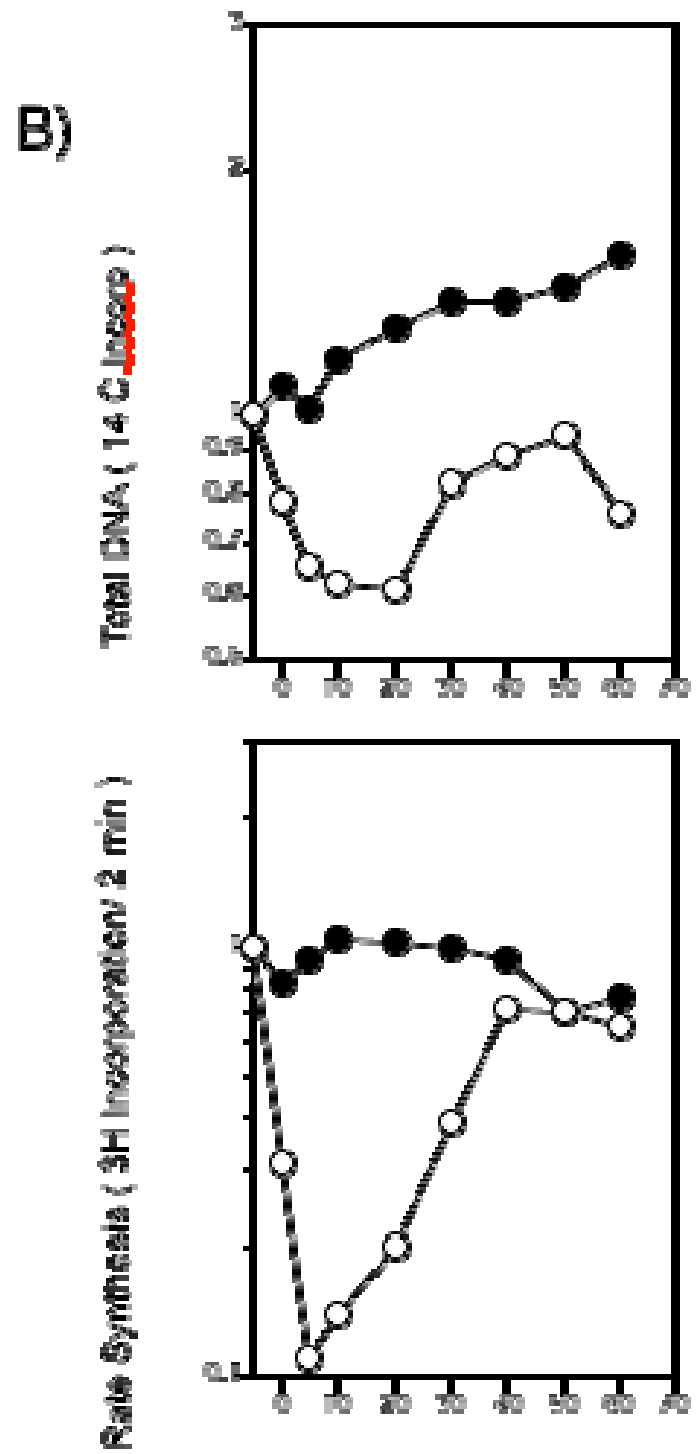

Trra ựin|

Figure (3): The absence of (A) NrdD or (B) NrdG does not prevent replication from recovering in the presence of hydroxyurea. . Cultures grown in media supplemented with $14 \mathrm{C}$-thymine were labeled with a pulse of $3 \mathrm{H}$-thymidine for 2 min at various time points following the addition of hydroxyurea. The amounts of $3 \mathrm{H}$ and $14 \mathrm{C}$ incorporated into the DNA (relative to pre treatment levels) are plotted over time. (Top) DNA accumulation; black circles, mock treatment; white circles, 100mM HU. (Bottom) Rate of Synthesis; black circles, mock treatment; white circles, $100 \mathrm{mM} \mathrm{HU}$. The initial amount of $3 \mathrm{H}$ and $14 \mathrm{C}$ at 5 minutes prior to treatment were 25536.5CPM and 3021CPM respectively in $n r d D$ mutant. The initial amount of $3 \mathrm{H}$ and $14 \mathrm{C}$ at 5 minutes prior to treatment were $32304.5 \mathrm{CPM}$ and $3506.5 \mathrm{CPM}$ respectively in $n r d G$ mutant. 


\section{Discussion}

The recovery of DNA synthesis after adding hydroxyurea in each mutant was unexpected as hydroxyurea is thought to inhibit the ribonucleotide reduction process which is essential for the replication to continue. Recovery of DNA synthesis after adding hydroxyurea in each mutant showed that neither the cryptic, $N r d E F$, or anaerobic $N r d D G$ reductases were responsible for this recovery. From these results, I hypothesize that there is another mechanism that was responsible for this recovery. One possibility is that replication in $E$. coli can resume despite reduced concentrations of dNTPs following hydroxyurea treatment. In future studies, it would be useful to follow the ribonucleotide pools over time in the presence of hydroxyurea to directly determine if the dNTP levels also recover, similar to replication.

A second possibility is that dNTP salvage pathways are up regulated. E.coli contains several pathways for importing dNTPs from the media which may allow some replication to recover (21). One could address this by looking at mutants having the salvage pathways inactivated, to see if replication is still able to recover in the presence of hydroxyurea.

A final possibility is that some mechanism exists by which the primary ribonucleotide reductase becomes resistant to hydroxyurea during periods of chronic exposure. Again, one could address this possibility by monitoring the dNTP pool levels during hydroxyurea treatment.

In this study, we showed that the recovery of DNA synthesis in the presence of hydroxyurea is not due to the alternative ribonucleotide reductases, NrdEF or NrdDG. 


\section{References}

Krakoff, I. H., Brown, N. C. \& Reichard, P. Inhibition of ribonucleoside diphosphate reductase by hydroxyurea. Cancer Res. 28, 1559-1565 (1968).

Brown, N. C. \& Reichard, P. Ribonucleoside diphosphate reductase. Formation of active and inactive complexes of proteins B1 and B2. J. Mol. Biol. 46, 25-38 (1969). http://dx.doi.org/10.1016/0022-2836(69)90055-2

Stubbe, J. Di-iron-tyrosyl radical ribonucleotide reductases. Curr Opin Chem Biol 7, 183-188 (2003). http://dx.doi.org/10.1016/S1367-5931(03)00025-5

Nordlund, P., Sjöberg, B. M. \& Eklund, H. Three-dimensional structure of the free radical protein of ribonucleotide reductase. Nature 345, 593-598 (1990).

http://dx.doi.org/10.1038/345593a0

Martin, J. E. \& Imlay, J. A. The alternative aerobic ribonucleotide reductase of Escherichia coli, NrdEF, is a manganese-dependent enzyme that enables cell replication during periods of iron starvation.Mol. Microbiol. 80, 319-334 (2011). http://dx.doi.org/10.1111/j.1365-

2958.2011.07593.x

Garriga, X. et al. nrdDandnrdGGenes Are Essential for Strict Anaerobic Growth of Escherichia coli. Biochemical and Biophysical Research Communications 229, 189-192 (1996).

http://dx.doi.org/10.1006/bbrc.1996.1778

Stearns, B., Losee, K. A. \& Bernstein, J. HYDROXYUREA. A NEW TYPE OF POTENTIAL ANTITUMOR AGENT. J. Med. Chem. 6, 201 (1963). http://dx.doi.org/10.1021/jm00338a026

Stauber, R. H. et al. A combination of a ribonucleotide reductase inhibitor and histone deacetylase inhibitors down regulates EGFR and triggers BIM-dependent apoptosis in head and neck cancer.Oncotarget 3, 31-43 (2011).

Piccinini, G, A Foli et al. "Complementary Antiviral Efficacy of Hydroxyurea and Protease Inhibitors in Human Immunodeficiency Virus-Infected Dendritic Cells and Lymphocytes." J Virol 76.5 (2002): 2274-78. http://dx.doi.org/10.1128/jvi.76.5.2274-2278.2002

Segal, J. B. et al. Hydroxyurea for the Treatment of Sickle Cell Disease. (Agency for Healthcare Research and Quality (US), 2008).

Yarbro, J. W. Mechanism of action of hydroxyurea. Seminars in oncology 19, 1-10 (1992).

Sakano, K., Oikawa, S., Hasegawa, K. \& Kawanishi, S. Hydroxyurea induces site-specific DNA damage via formation of hydrogen peroxide and nitric oxide. Jpn. J. Cancer Res. 92, 11661174 (2001). http://dx.doi.org/10.1111/j.1349-7006.2001.tb02136.x 
Davies, B. W. et al. Hydroxyurea induces hydroxyl radical-mediated cell death in Escherichia coli. Mol Cell 36, 845-860 (2009).

http://dx.doi.org/10.1016/j.molcel.2009.11.024

Timson, J. Hydroxyurea. Mutat. Res. 32, 115-132 (1975).

http://dx.doi.org/10.1016/0165-

$\underline{1110(75) 90002-0}$

Young, C. W., Schochetman, G., Hodas, S. \& Balis, M. E. Inhibition of DNA synthesis by hydroxyurea: structure-activity relationships. Cancer Res. 27, 535-540 (1967).

Koç, A., Wheeler, L. J., Mathews, C. K. \& Merrill, G. F. Hydroxyurea arrests DNA replication by a mechanism that preserves basal dNTP pools. J. Biol. Chem. 279, 223-230 (2004). http://dx.doi.org/10.1074/ibc.M303952200

Savic, Neda. "Characterization of the Replication Rate and Intermediates Produced Following Hydroxyurea Treatment in Escherichia Coli." Portland State University. University Honors Thesis, 2012.

Mellon, I. \& Hanawalt, P. C. Induction of the Escherichia coli lactose operon selectively increases repair of its transcribed DNA strand. Nature 342, 9598 (1989). http://dx.doi.org/10.1038/342095a0

Davis, BD. The Isolation of Biochemically Deficient Mutants of Bacteria by Means of Penicillin. Proc Natl Acad Sci USA 35, 1-10 (1949).

http://dx.doi.org/10.1073/pnas.35.1.1

Baba, T. et al. Construction of Escherichia coli K-12 in-frame, single-gene knockout mutants:

the Keio collection. Mol SystBiol 2, 2006.0008 (2006).

Schaaper, R. M. \& Mathews, C. K. Mutational consequences of dNTP pool

imbalances in E. coli. DNA Repair (Amst) 12, 73-79 (2013).

http://dx.doi.org/10.1016/j.dnarep.2012.10.011 